\title{
Marine Mineral Resources of Pacific Islands-A Review of the Exclusive Economic Zones of Islands of U.S. Affiliation, Excluding the State of Hawaii
}

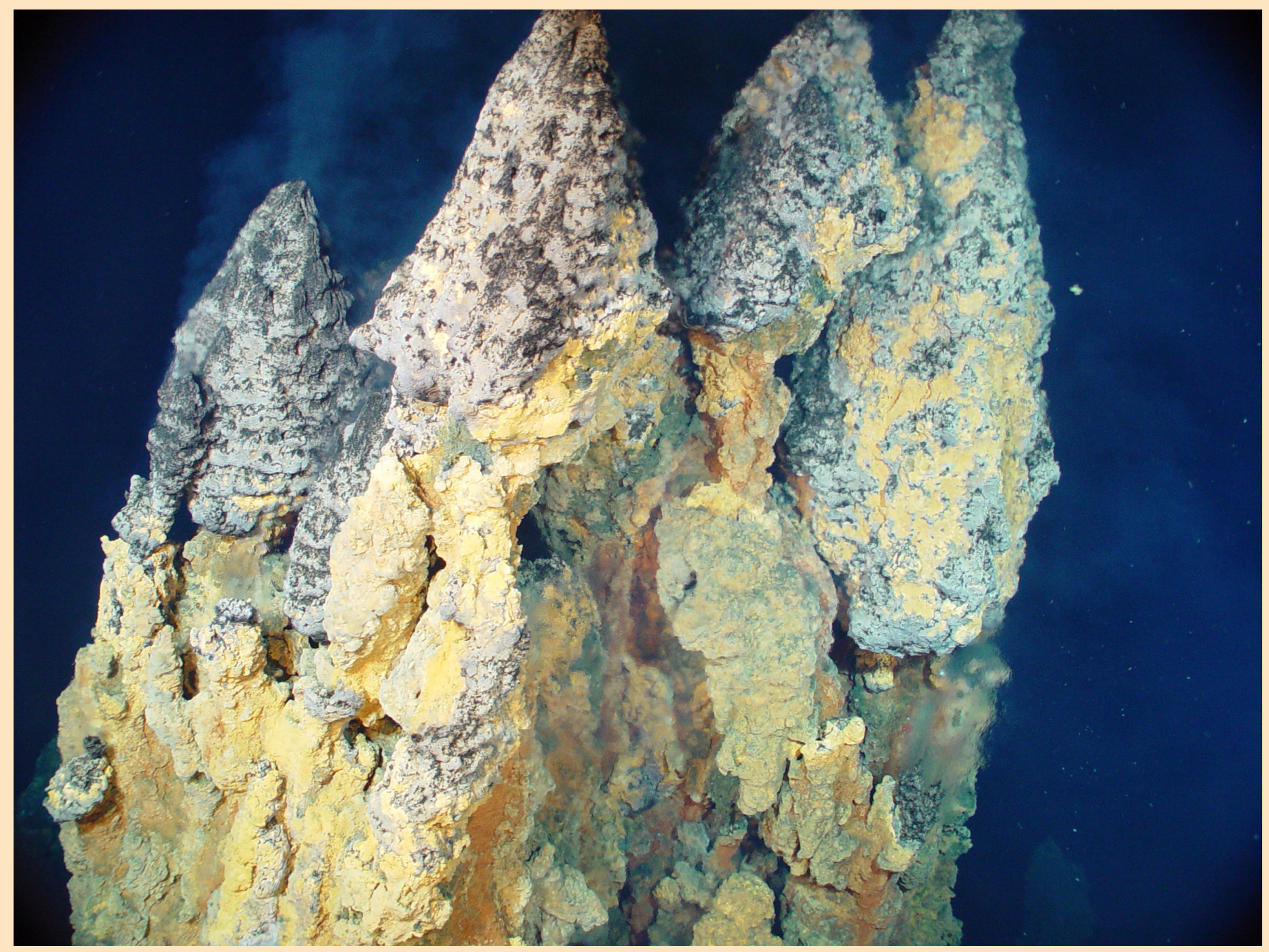

Circular 1286 


\section{Marine Mineral Resources of Pacific Islands-A Review of the Exclusive Economic Zones of Islands of U.S. Affiliation, Excluding the State of Hawaii}

By James R. Hein, Brandie R. McIntyre, and David Z. Piper

Circular 1286 


\section{U.S. Department of the Interior \\ Gale A. Norton, Secretary}

\section{U.S. Geological Survey \\ P. Patrick Leahy, Acting Director}

\section{U.S. Geological Survey, Reston, Virginia: 2005}

For sale by U.S. Geological Survey Information Services

Box 25286, Denver Federal Center

Denver, C0 80225-0046

This report and any updates to it are available online at: http://pubs.usgs.gov/circular/c1286/

For additional information write to:

U.S. Geological Survey

Box 25046, Mail Stop 421, Denver Federal Center

Denver, C0 80225-0046

Additional USGS publications can be found at:

http://geology.usgs.gov/products.html

For more information about the USGS and its products:

Telephone: 1-888-ASK-USGS (1-888-275-8747)

World Wide Web: http://www.usgs.gov/

Any use of trade, product, or firm names in this publication is for descriptive purposes only and does not imply endorsement by the U.S. Government.

Although this report is in the public domain, it may contain copyrighted materials that are noted in the text. Permission to reproduce those items must be secured from the individual copyright owners.

\section{Cataloging-in-Publication data are on file with the Library of Congress}

Produced in the Western Region, Menlo Park, California Manuscript approved for publication, September 26, 2005

Text edited by Peter H. Stauffer

Layout and design by Stephen L. Scott

FRONT COVER

Active sulfide chimneys on the sea bottom at a depth of 345 meters (1,130 feet) in the western Pacific (see p. 5). 


\section{Contents}

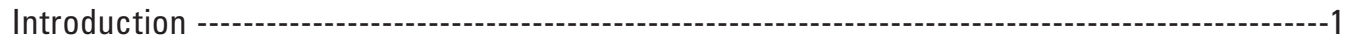

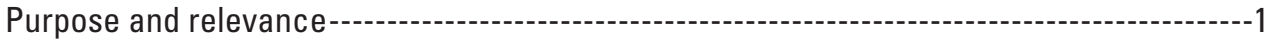

Marine mineral deposits: occurrence and formation ---

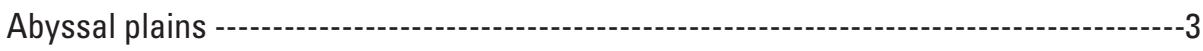

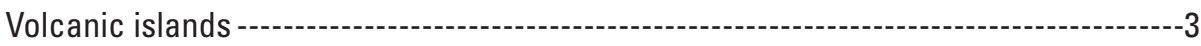

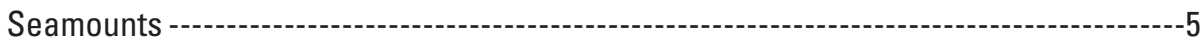

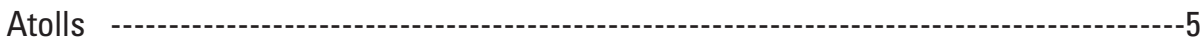

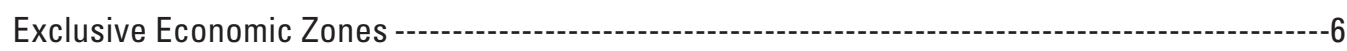

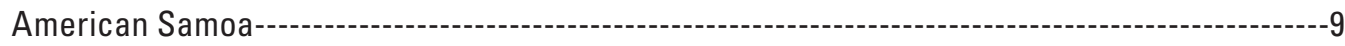

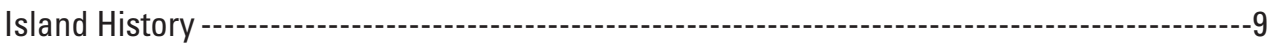

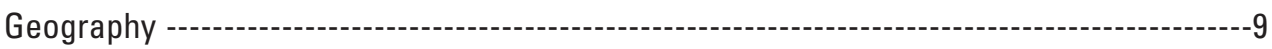

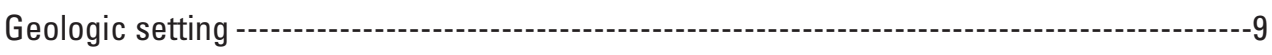

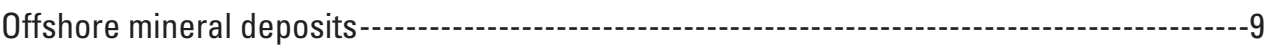

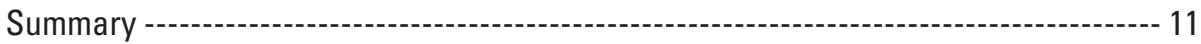

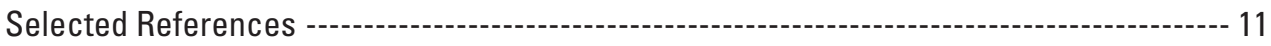

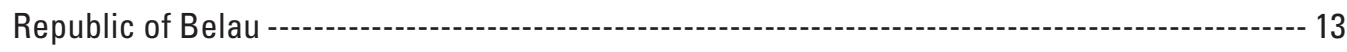

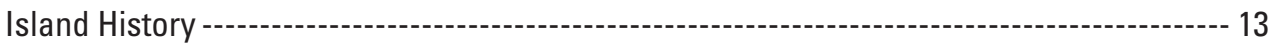

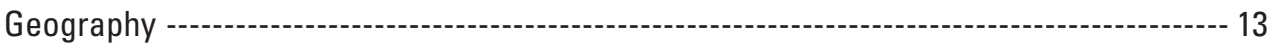

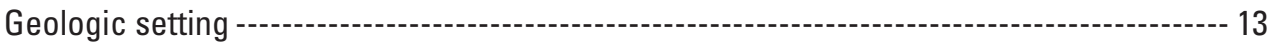

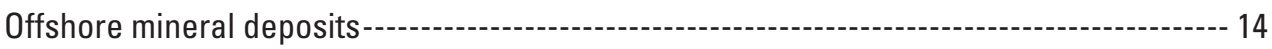

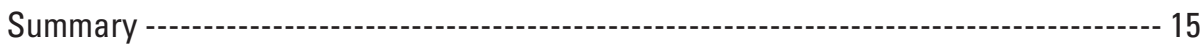

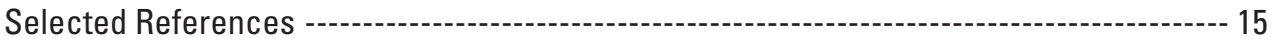

Guam--19 19

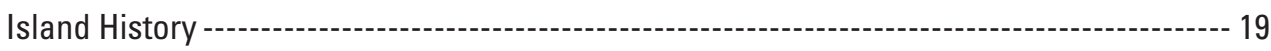

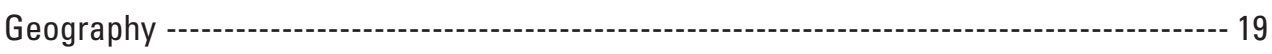

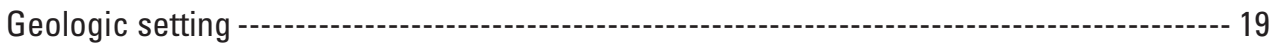

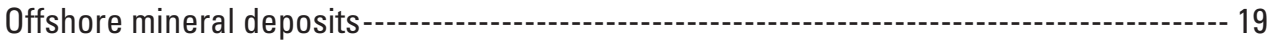

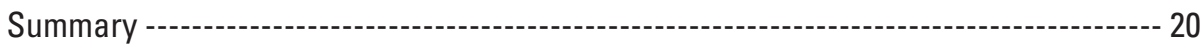

Selected References --- 21

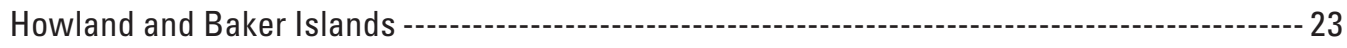

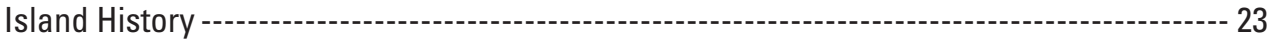

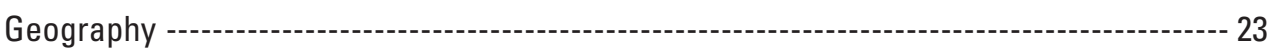

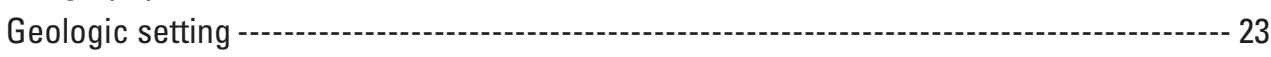

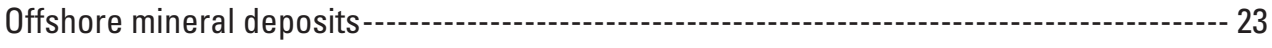

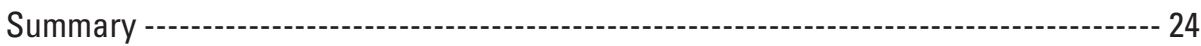

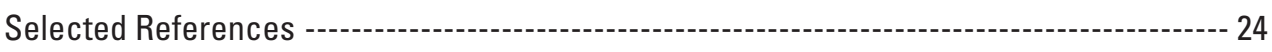

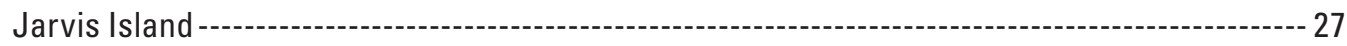




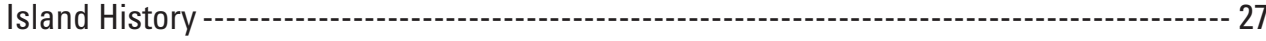

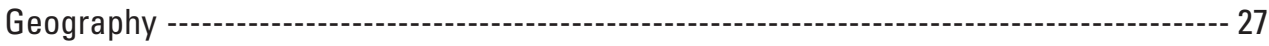

Geologic setting --- 27

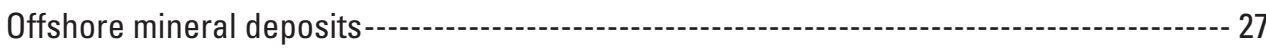

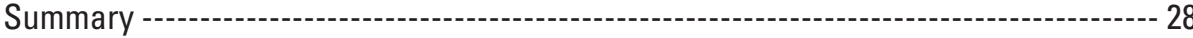

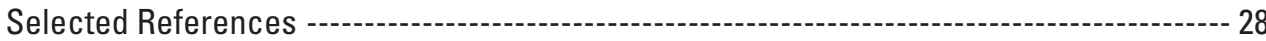

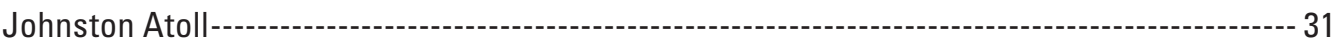

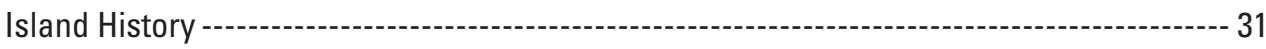

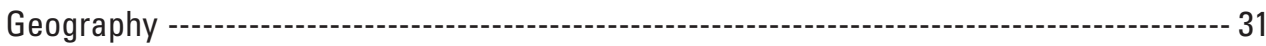

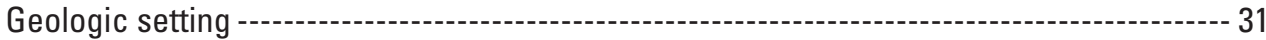

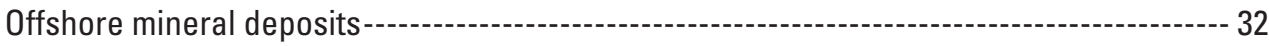

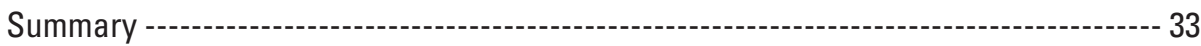

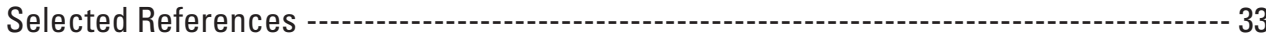

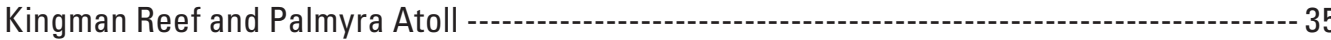

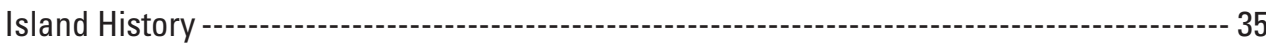

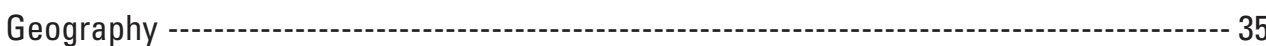

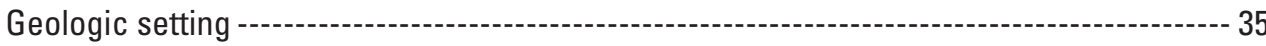

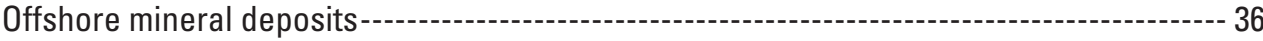

Summary ----- 37

Selected References --- 37

Republic of Marshall Islands --- 39

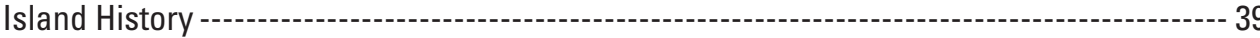

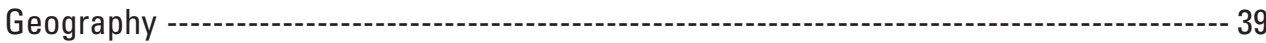

Geologic setting ----- 39

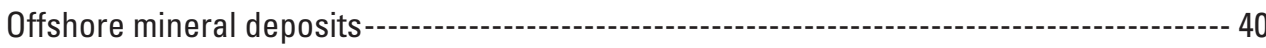

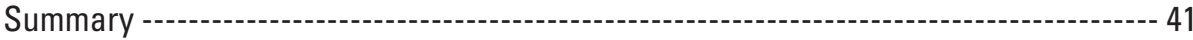

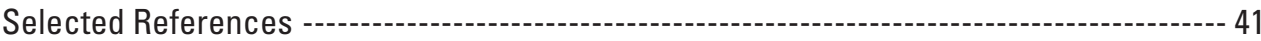

Federated States of Micronesia-- 43

Island History ------- 43

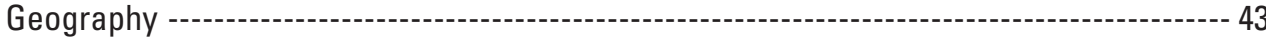

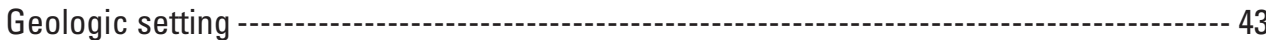

Offshore mineral deposits---

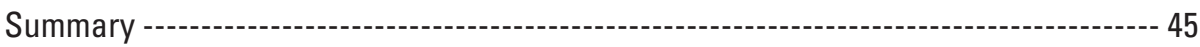

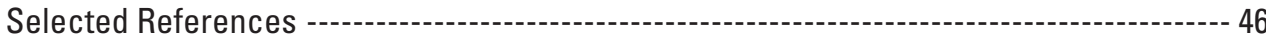

Midway Atoll --:--:--o- 49

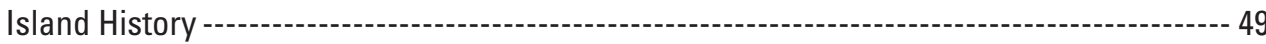

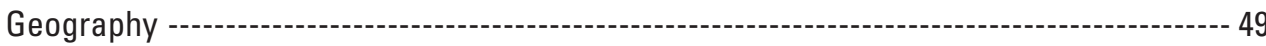

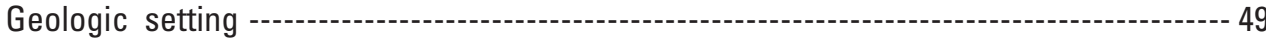

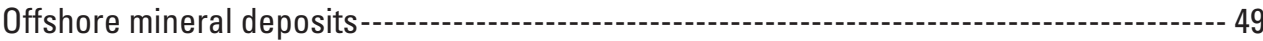

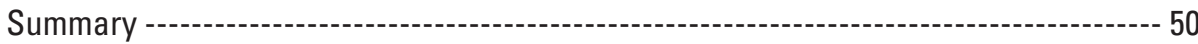

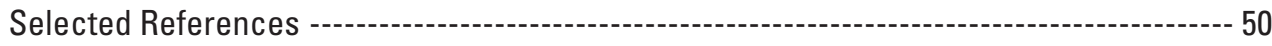

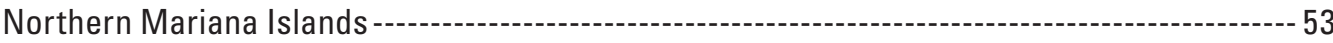

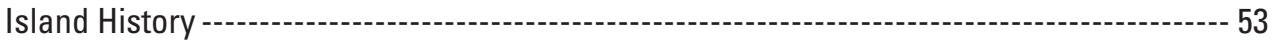




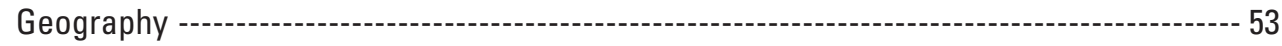

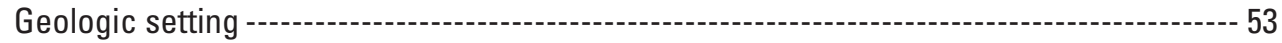

Offshore mineral deposits--- 53

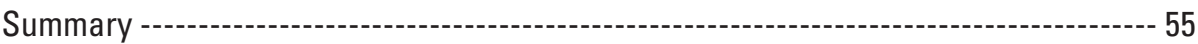

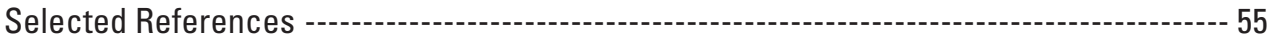

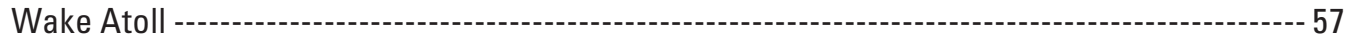

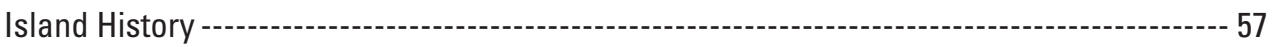

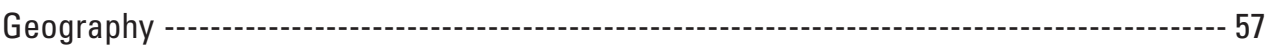

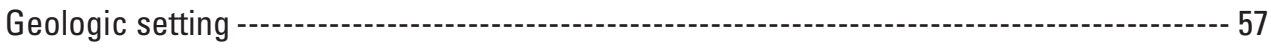

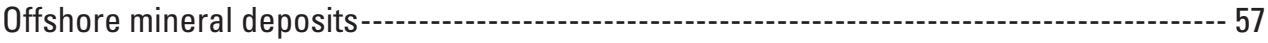

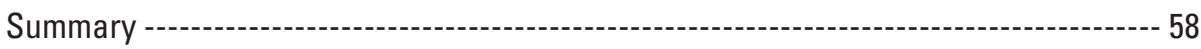

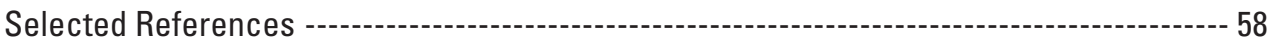

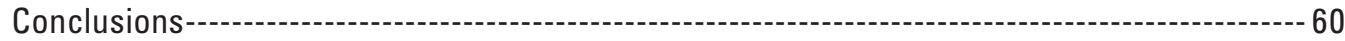

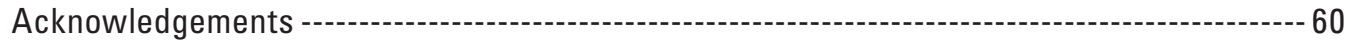

\section{Appendixes}

1. Metric system conversion factors ---

2. Definitions and explanation --- 60

3. Acronyms and abbreviations--- 62

\section{Figures}

1. Index map of the Pacific region, showing unofficial Exclusive Economic Zones------------2

2. Schematic diagram of oceanic tectonic and physiographic settings where deep-sea mineral deposits form------------------------------------------------4

3. Photograph of iron-manganese nodules on the sea floor in the Johnston Atoll EEZ -------4

4. Photograph of the cross section of an abyssal iron-manganese nodule ------------------4

5. Photograph of a group of active sulfide chimneys collected from the Northern

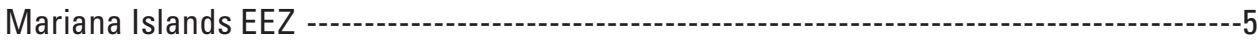

6. Photograph of the cross section of an 18-centimeter-thick iron-manganese

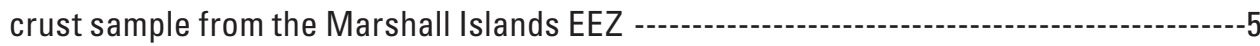

7. Ocean-floor photograph of iron-manganese crust pavement on Horizon Guyot,

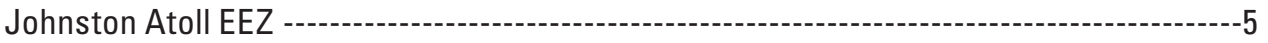

8. Photograph showing laborers from Belau and Yap working in the phosphate mines on Ngeaur Island, Belau, during World War II---

9-20.Bathymetric maps of individual EEZs:

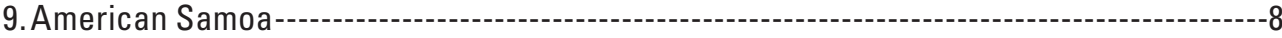

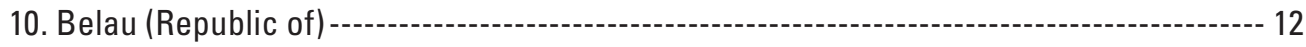

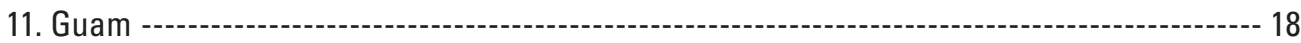

12. Howland and Baker Islands---.-- 22 


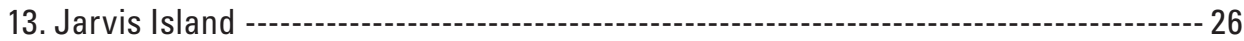

14. Johnston Atoll --- 30

15. Kingman Reef and Palmyra Atoll--- 34

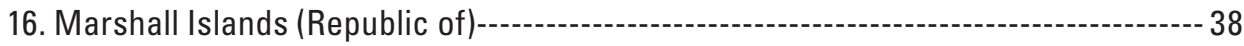

17. Micronesia (Federated States of)----.--

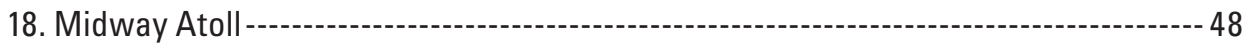

19. Northern Mariana Islands (Commonwealth of)---

20. Wake Atoll----- 56

21. Map showing the main potential deep-water mineral deposit type and contained

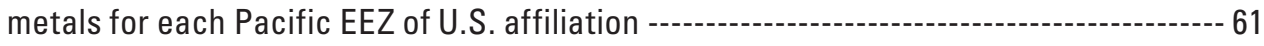




\title{
Marine Mineral Resources of Pacific Islands-A Review of the Exclusive Economic Zones of Islands of U.S. Affiliation, Excluding the State of Hawaii
}

\author{
By James R. Hein', Brandie R. McIntyre', and David Z. Piper ${ }^{1}$
}

\section{Introduction}

\section{Purpose and Relevance}

The United States Exclusive Economic Zone (EEZ) was established in 1983 and comprises all marine areas within 200 nautical miles (370 kilometers; see appendix 1 for conversion factors) of the nearest U.S. land. This vast area of 3.38 million square nautical miles (11.6 million square kilometers) is about 20 percent greater than the entire land area of the United States. The resource potential of the vast mineral deposits that occur within the U.S. EEZ is unknown, despite field studies that have taken place during the past 25 years. Since about 1975, information on marine mineral deposits has been obtained by numerous research cruises to the Pacific Ocean by the U.S. Geological Survey (USGS), the U.S. National Oceanic and Atmospheric Administration (NOAA), equivalent government agencies in Germany, Canada, France, Russia, Japan, China, South Korea, Australia, and New Zealand, and by academic researchers from all of these nations. Although most of the cruises by other nations explored areas outside the U.S. EEZ, information gained from those studies can aid in the evaluation of the mineral potential in the U.S. EEZ. However, the global effort remains inadequate to allow for the quantitative evaluation of mineral resources contained within the EEZ of nations or within international regions of the oceans.

Quantitative information about U.S. EEZ resources is essential if governments are to make informed decisions about (1) competitive land (sea)-use issues, (2) outer continentalmargin boundary negotiations, (3) environmental-contaminant issues, and (4) energy, mineral, and biologic resources potential. The last includes homeland-security concerns such as self-sufficiency in energy and strategic and critical mineral resources. This report assesses our current state of knowledge concerning nonrenewable mineral resources within the EEZ of the Pacific islands of U.S. affiliation, exclusive of the State of Hawaii. These islands include the U.S. Commonwealth of the Northern Mariana Islands; U.S. Territories of Guam, Midway Atoll, Wake Atoll, Johnston Atoll, Jarvis Island, Howland-Baker Islands, Kingman-Palmyra Atolls, and American Samoa; and the Compact of Freely Associated Nations, which comprises three independent nations - the Republic of the Marshall Islands, Republic of Belau (Palau), and the Federated States of Micronesia (see fig. 1).

A critical concern of coastal nations today is the issue of the limits of the outer continental margin and the possibility of extending EEZ boundaries on the basis of new geologic criteria. A nation's knowledge of the geology and mineral resources in adjacent marine areas is essential in determining the placement of EEZ boundaries. Many Pacific island nations have few options for generating revenue, and valuable mineral resources in the EEZ could offer these nations economic relief.

Many U.S. Government agencies (USGS, Department of State, Office of Insular Affairs, Minerals Management Service, National Oceanic and Atmospheric Administration) and international agencies (South Pacific Applied Geoscience Commission, International Seabed Authority) regularly receive requests from Pacific island nations for information about their EEZ resources. However, our ability to provide information on resource potential for the U.S. EEZ and those of the Compact of Freely Associated Nations is limited by the lack of systematic studies, despite reconnaissance work that has taken place during the past several decades. New concerns about homeland security in terms of self-sufficiency in energy and critical and strategic minerals now demand that potential contributions from the EEZ be understood and considered in calculations of mineral assessments of the United States. Emerging markets for metals in Asia and rapidly developing technologies for fuel-cell and hybrid cars will significantly increase global demands for copper, nickel, cobalt, and platinum. These are among the most common metals found in deep-sea mineral deposits, which will be needed to meet these growing demands. The USGS has a long history of data collection and analysis from Pacific islands EEZs. That knowledge base, combined with published and unpublished databases, can be used to assess our current state of knowledge and ascertain what is necessary for quantitative resource assessments. At a time when on-land mining faces ever-increasing environmental restrictions and policymakers are confronted with increasingly more difficult decisions about land-use priorities, it behooves the United States to evaluate the distribution of minerals offshore and assess their resource potential.

1345 Middlefield Road, Menlo Park, CA 94025 


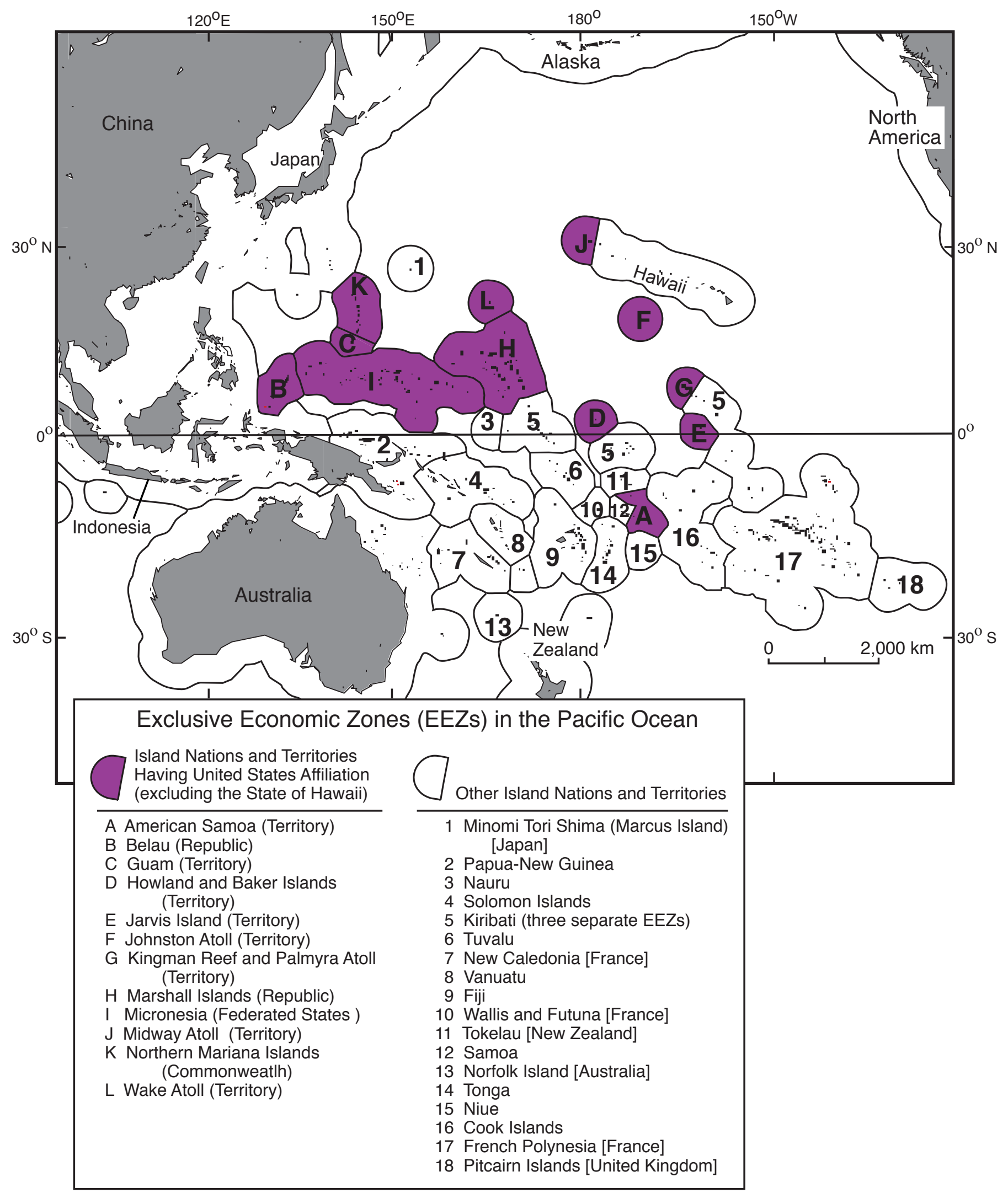

Figure 1. Index map of the Pacific region, showing unofficial Exclusive Economic Zones (200-nautical-mile limits) extending from the shores of nations and territories. Those with affiliations to the United States are shaded in purple and are discussed in this circular. Most seamounts in the Pacific Ocean are within 200 nautical miles of islands. Consequently, much of the potential seamount resources occur within the EEZs shown. (Modified from the Web site of SOPAC, www.sopac.org.fj) 


\section{Marine Mineral Deposits: Occurrence and For- mation}

For each EEZ considered, this compilation presents information, when available, for aggregate, sand and gravel, precious coral, insular and seamount (submarine volcano) phosphorites, cobalt-rich iron-manganese crusts (also known as ferromanganese crusts, manganese crusts, or cobalt crusts), iron-manganese nodules (also known as ferromanganese nodules or manganese nodules), hydrothermal manganese, polymetallic sulfides, sulfates, sulfur, epithermal gold and base metals, and sedimentary native copper. Data gaps are identified and recommendations made for filling them. For sites where no samples have been collected, and therefore no data exist, some inferences are made about the minerals likely to occur based on our knowledge of their modes of formation and the geologic environments in which they are known to occur. A brief geologic summary of each EEZ is provided in order to understand the minerals that may occur there in a larger context.

To a first approximation, islands and surrounding environments in the Pacific Ocean basin can be divided into four geological/oceanographic settings. These settings dictate the mineral deposit types possibly hosted within the EEZ of an island or island nation. These environments and the main mineral deposit types (given in boldface type at first use) that occur in each are here described briefly. A schematic representation of these geologic environments is presented in figure 2 .

\section{Abyssal Plains}

The deep abyssal plains (water depths of 4,000 to 6,500 meters; 13,100 to 21,300 feet) are relatively flat and sediment covered. Iron-manganese nodules commonly form on the sea floor where the sediment accumulation rates are low, less than 10 centimeters (4 inches) per thousand years (figs. 3, 4). Nodule coverage over vast areas of the Pacific Ocean sea floor exceeds 50 percent. The nodules are composed mainly of iron and manganese oxides, but it is their few weight percent of copper $(\mathrm{Cu})$ plus nickel $(\mathrm{Ni})$ and cobalt $(\mathrm{Co})$ that make them of economic interest. The primary source of the metals in the nodules is ocean water. Nodules form by precipitation of metals directly from cold, ambient bottom waters onto the tops of nodules and by precipitation from sediment pore fluids onto the bottoms of nodules. The metals supplied to the pore fluids were initially part of accumulating organic matter or were adsorbed on organic and inorganic solids that settled through the water column to the ocean floor. The two processes yield precipitates of quite different composition. The first type (direct precipitation from sea water) results in iron/manganese ratios of 0.5 to 1.5 and relatively high cobalt contents, in the range of 0.5 percent. The second type (precipitation from pore fluids) has lower iron/manganese ratios, commonly in the range of 0.2 to 0.5 , and relatively high combined $\mathrm{Cu}$ and $\mathrm{Ni}$ concentrations, as much as 3 percent.
This difference in composition is recorded within the nodules and demonstrates quite clearly that the nodules must be periodically reoriented on the ocean floor during accretion. An unsolved problem is how the nodules can remain at the surface and grow large. The nodules accrete metals from seawater at a rate that is about 1,000 times slower than the accumulation rate of the sediment on which the nodules rest. The reorientation or turning of the nodules apparently keeps them from being buried by the more rapidly accumulating sediment. Given that the nodules in many areas average several centimeters in diameter and that bottom currents are too weak to move the nodules, the mechanism of turning them over is not well understood. Turning of the nodules is possibly related to the burrowing of fauna that populate the uppermost few centimeters of sediment, including anemones, holothurians, and mollusks, among others. This question is not merely academic, because maintaining the nodules at the surface is essential for their easy recovery during mining.

\section{Volcanic Islands}

Three different environments within the Pacific Basin host volcanic activity that can lead to the formation of islands:

Spreading ridges. Along these ridges, such as the East Pacific Rise, new oceanic crust is created by the outpouring of lava along the ridge crest, a process that forms new ocean floor continuously on a geologic time scale. The sea floor is very young at the spreading-ridge axis and progressively older away from the ridge. This creation of new sea floor occurs at a rate of a few to a few tens of centimeters per year. This type of volcanism rarely forms islands; the best examples are the Galapagos Islands in the Pacific and Iceland in the Atlantic. Seamounts (submerged volcanoes) are a common product of this type of volcanism (see Seamounts below).

Hot spots. Some oceanic volcanoes form above a stationary magma chamber deep within the Earth. Magma rising from such a chamber erupts on the sea floor and builds a chain of volcanoes as the ocean crust moves over the hot spot as the result of sea-floor spreading. The classic example of such a chain is the Hawaiian archipelago, in which the Island of Hawai'i with its active volcanoes is now positioned over the hot spot. In the past, the islands now to the northwest formed progressively over the hot spot and then moved away. Thus, Maui is older than Hawai'i, and Hawai'i did not exist when Maui was over the hot spot; Molokai is older than Maui, Oahu older yet, and Kauai still older. This type of volcanism forms many islands as well as seamounts.

Deep-sea trenches. The Mariana Trench exemplifies these features, where the Pacific Ocean crust is subducted (descends) deep into the Earth's mantle. Subduction creates a sea-floor trench and also a chain of volcanic islands (such as the Mariana, Yap, and Belau volcanic arcs) above the deeper parts of the subduction zone, where part of the subducted ocean crust is melted. The magma from that melting rises and erupts as lava on the sea floor, eventually building volcanic islands. Farther away from the ocean trenches, behind the vol- 


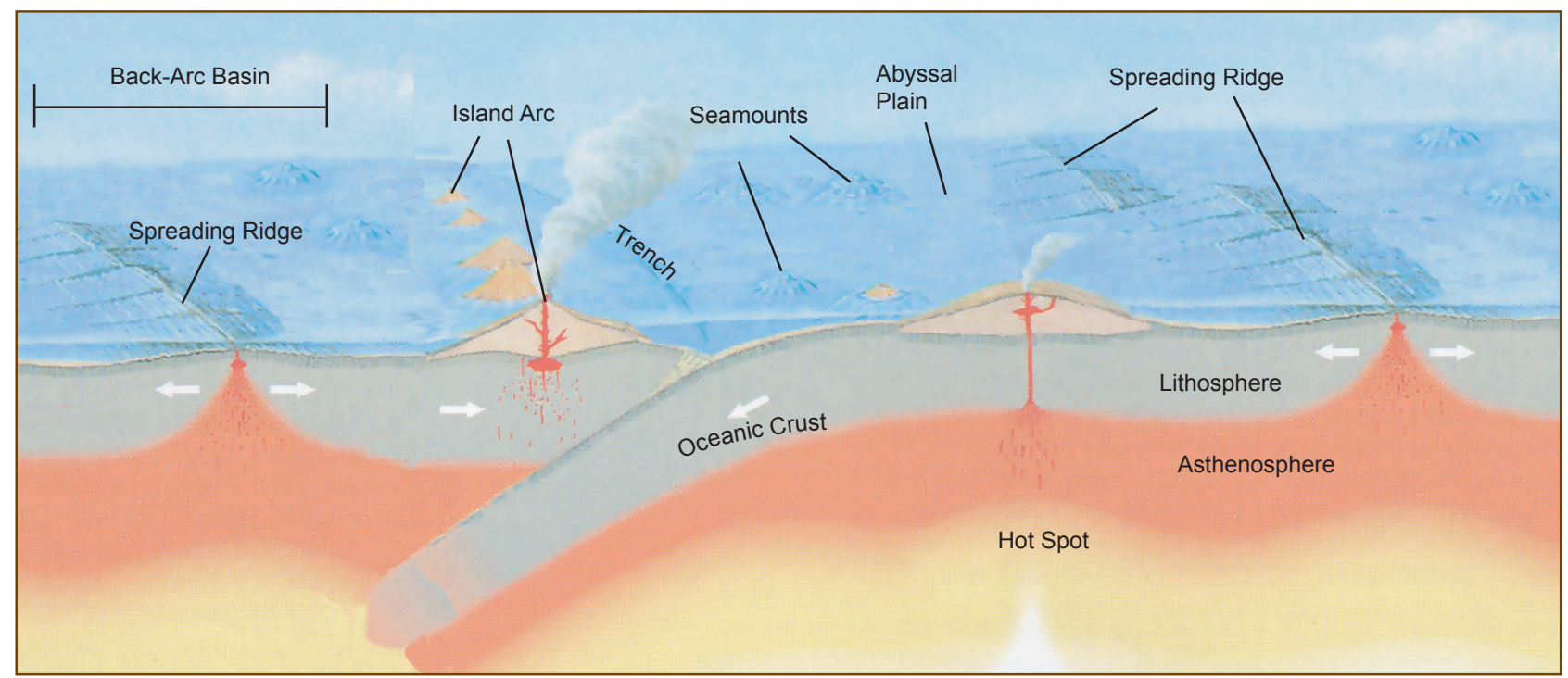

Figure 2. Schematic diagram of oceanic, tectonic, and physiographic settings where deep-sea mineral deposits form. Hydrothermal mineral deposits form along oceanic and back-arc-basin spreading ridges, along island arcs, and at hot-spot volcanoes. Ferromanganese crusts form on the flanks of seamounts and islands, and ferromanganese nodules form on the abyssal sea floor (modified from Jose F. Vigil's illustration in This Dynamic Planet, a wall map published in 1994 jointly by the USGS, Smithsonian Institution, and the U.S. Naval Research Laboratory).

canic arc, a type of sea-floor spreading and volcanism called back-arc-basin spreading occurs on a smaller scale than at oceanic ridges. The volcanism that results from this type of sea-floor spreading rarely forms islands, but it is nonetheless important to the formation of marine mineral deposits.

Hydrothermal activity is associated with all three of these types of volcanism. Polymetallic sulfides, sulfates, and sulfur may precipitate from the hydrothermal/magmatic fluids asso-

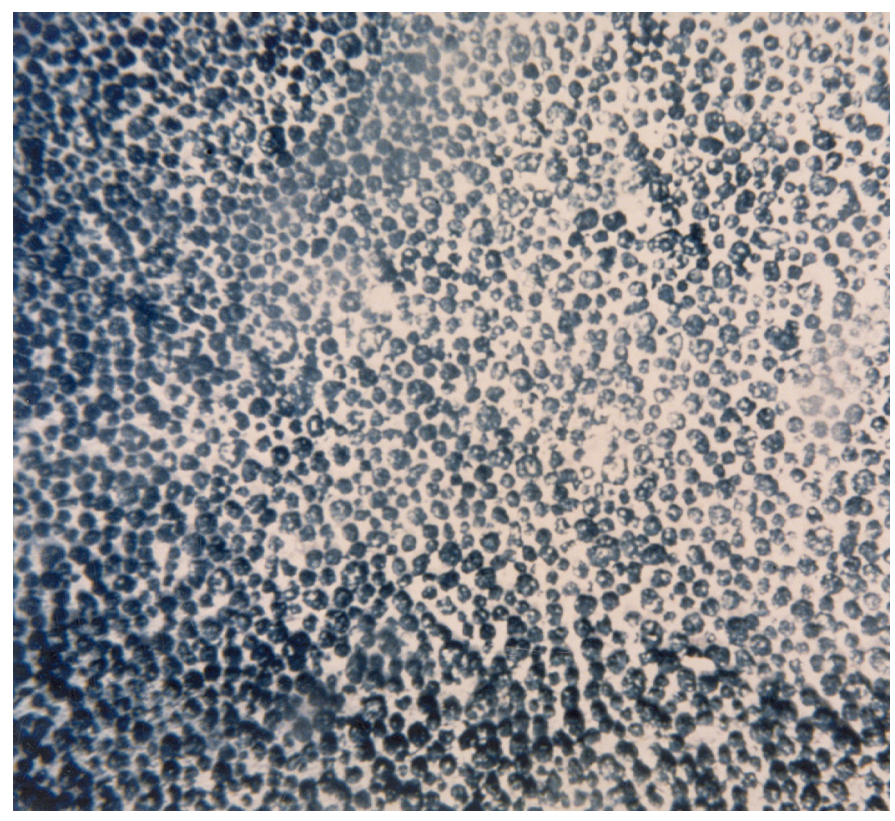

Figure 3. A dense concentration of iron-manganese nodules in the Johnston Atoll EEZ; field of view is about 4 meters by 3 meters. ciated with the volcanism (fig. 5). Epithermal gold and basemetal deposits form within volcanic arcs, but at deeper levels within the volcanic pile. They may be brought to the surface by uplift, faulting, and erosion.

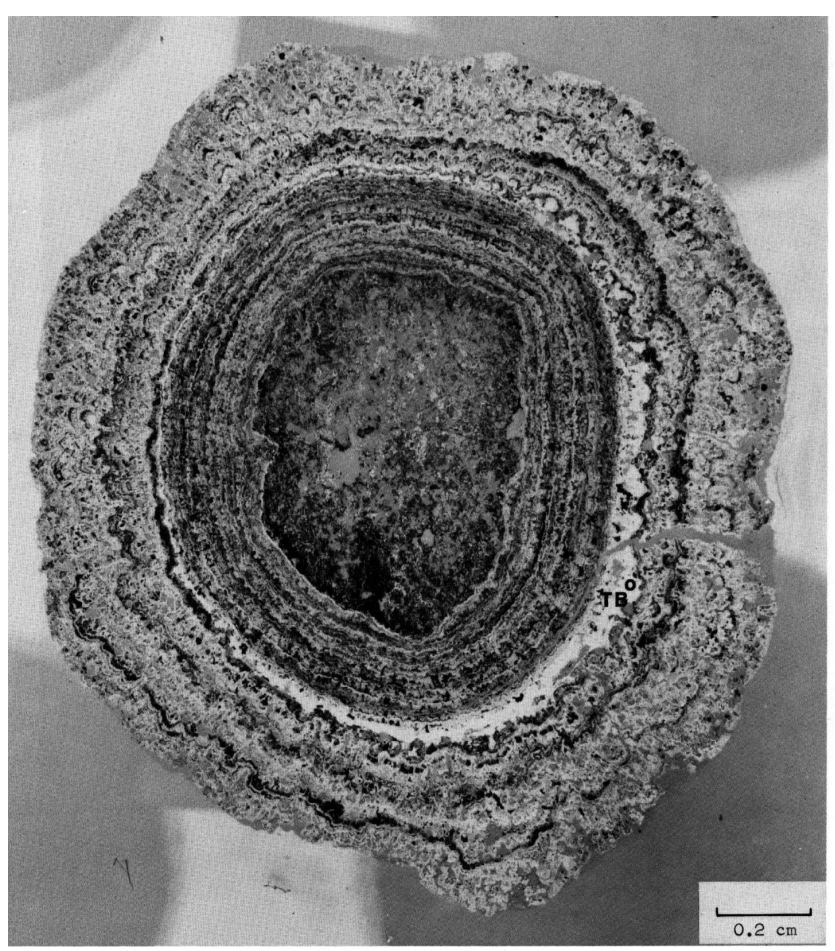

Figure 4. Cross section of an abyssal iron-manganese nodule; approximate diameter is 1.5 centimeters. Note the concentric, wavy growth layers that reflect differences in composition. 


\section{Seamounts}

Seamounts are submarine volcanoes that may be active currently or may have been extinct for millions of years. They do not now extend above the ocean surface as islands, but some were once islands. However, once the volcanoes that built them became dormant, adjustments of the ocean crust (weight of the volcanic pile and cooling of the crust) caused

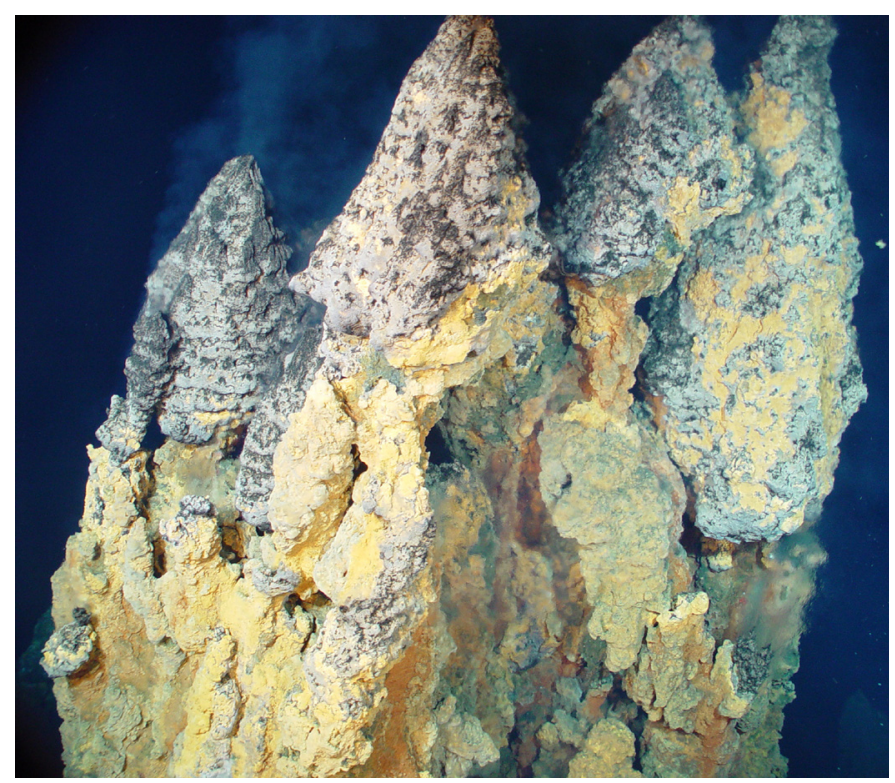

Figure 5. A group of active sulfide chimneys from the Northern Mariana Islands EEZ; note the gray particulate matter above and to the right of the group of chimneys, which originates from the orifice of each individual chimney. Water depth is 345 meters. (http://oceanexplorer.noaa.gov/explorations/04fire/)

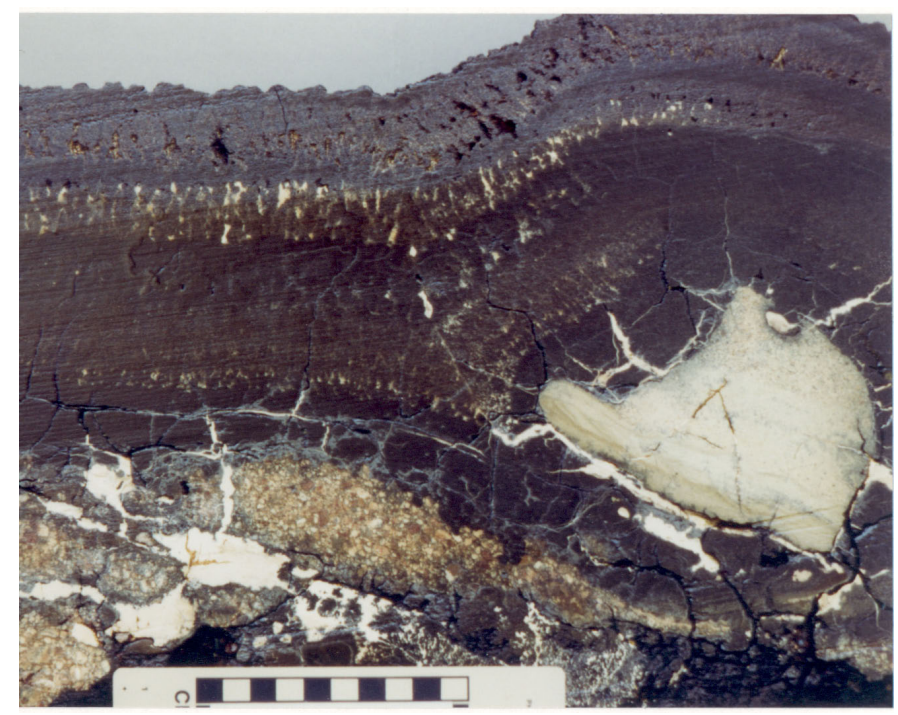

Figure 6. A cross-section of an 18-centimeter-thick iron-manganese crust sample from the Marshall Islands EEZ; collected from 1,780meter water depth. them to sink as much as 2 kilometers ( 1.24 miles) by a process called isostatic compensation. It has been estimated that about 50,000 seamounts are present in the Pacific Ocean. As might be expected, they occur over a wide range of water depths.

Flat-topped seamounts, known as guyots, were at one time islands. Their tops were eroded flat by surface waves as the edifices sank following cessation of volcanic construction. Conical seamounts were likely never islands, but rather were always submerged. Most seamounts in the central Pacific are 110 to 65 million years old (Cretaceous) and have not been volcanically active for tens of millions of years. In contrast, seamounts along the East Pacific Rise in the eastern Pacific and along volcanic arcs in the western Pacific are young and currently support volcanic and hydrothermal activity.

Cobalt-rich iron-manganese crusts and phosphorite deposits are ubiquitous on old seamounts in the Pacific (fig. 6). Iron-manganese crusts grow at rates of about 1 to 6 millimeters ( 0.04 to 0.24 inches) per million years by precipitation of metals out of cold ambient bottom waters onto hard-rock substrates (fig. 7). Their growth rates are on average about 4 to 6 times slower than those of copper- and nickel-rich iron-manganese nodules. The crusts form where the seamounts are free of sediment. Like nodules, the crusts are composed mainly of iron and manganese oxides, but it is their high cobalt contents ( 0.5 to 2.0 percent) that make them of economic interest. Crusts commonly have high contents of other metals that are of economic interest as well, including titanium, cerium, nickel, zirconium, platinum, molybdenum, copper, and tellurium.

\section{Atolls}

Like seamounts and guyots, atolls are linked to the formation of volcanic islands and their eventual sinking in response to adjustments of the oceanic crust. Charles Darwin was the first to recognize their origin, and his explanation is still

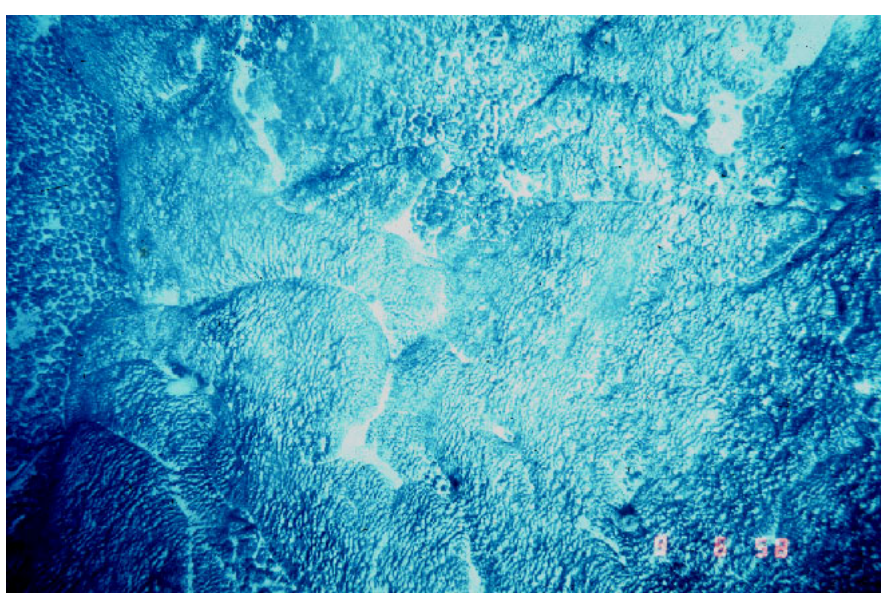

Figure 7. Ocean-floor photograph of iron-manganese crust pavement on Horizon Guyot, Johnston Atoll EEZ; image covers about 3 meters by 4 meters of sea floor at 2,000-meter water depth. 
accepted today. Low-latitude $\left(0-30^{\circ}\right)$ volcanic islands develop barrier reefs, an important structural element of which is calcium carbonate secreted by corals and algae. A vast community of other organisms and their remains also contribute to the building and maintenance of the reefs. As volcanic islands sink, fringing reefs grow upward and become barrier reefs with shallow lagoons between the reefs and the islands. With the continued subsidence of the island below sea level and continued upward growth of the reef, formation of the atoll is complete. The exposed reef becomes more or less continuous, encircling an inner lagoon, and there may be no visual evidence of the totally submerged underlying volcanic edifice.

Some ancient atolls have been uplifted by movement of the oceanic crust over swells in the Earth's mantle (called lithospheric swells). These former atolls have been transformed into carbonate platform islands with as much as 90 meters of elevation. Perhaps the best known is the island of Nauru, in the western part of the equatorial Pacific Ocean, but many others exist.Several atolls and carbonate platform islands had significant deposits of lagoonal or insular phosphates, most of which were mined in the early part of the $20^{\text {th }}$ century (fig. 8). On Nauru, site of by far the largest such deposit, mining continued throughout the $20^{\text {th }}$ century. The source of this phosphate was bird guano. The vast avian colony required for the formation of the deposit occupied the island from the time when it was still an atoll until it became totally emergent, and possibly for some time thereafter. The phosphate deposit on the Chincha Islands along the coast of Peru demonstrates the existence of such prodigious guano sources. There, the compacted and altered guano phosphate deposit was approximately 45 meters thick. As fresh guano, accumulating at a rate of several meters per 100 years, the Chincha deposit would have been in excess of $400 \mathrm{~m}$ thick. The deposits on Nauru required approximately this same remarkable amount of fresh guano.

Understanding these different environments makes it possible to predict the mineral-deposit types that are likely to occur within a given EEZ, even if no samples have been collected. However, without detailed sampling and mapping of an area, it is not possible to make a quantitative mineral resource assessment.

\section{Exclusive Economic Zones}

Information for each of the 12 island territories considered here is organized into two parts: The first part is introductory material consisting of land area, EEZ area, political status,

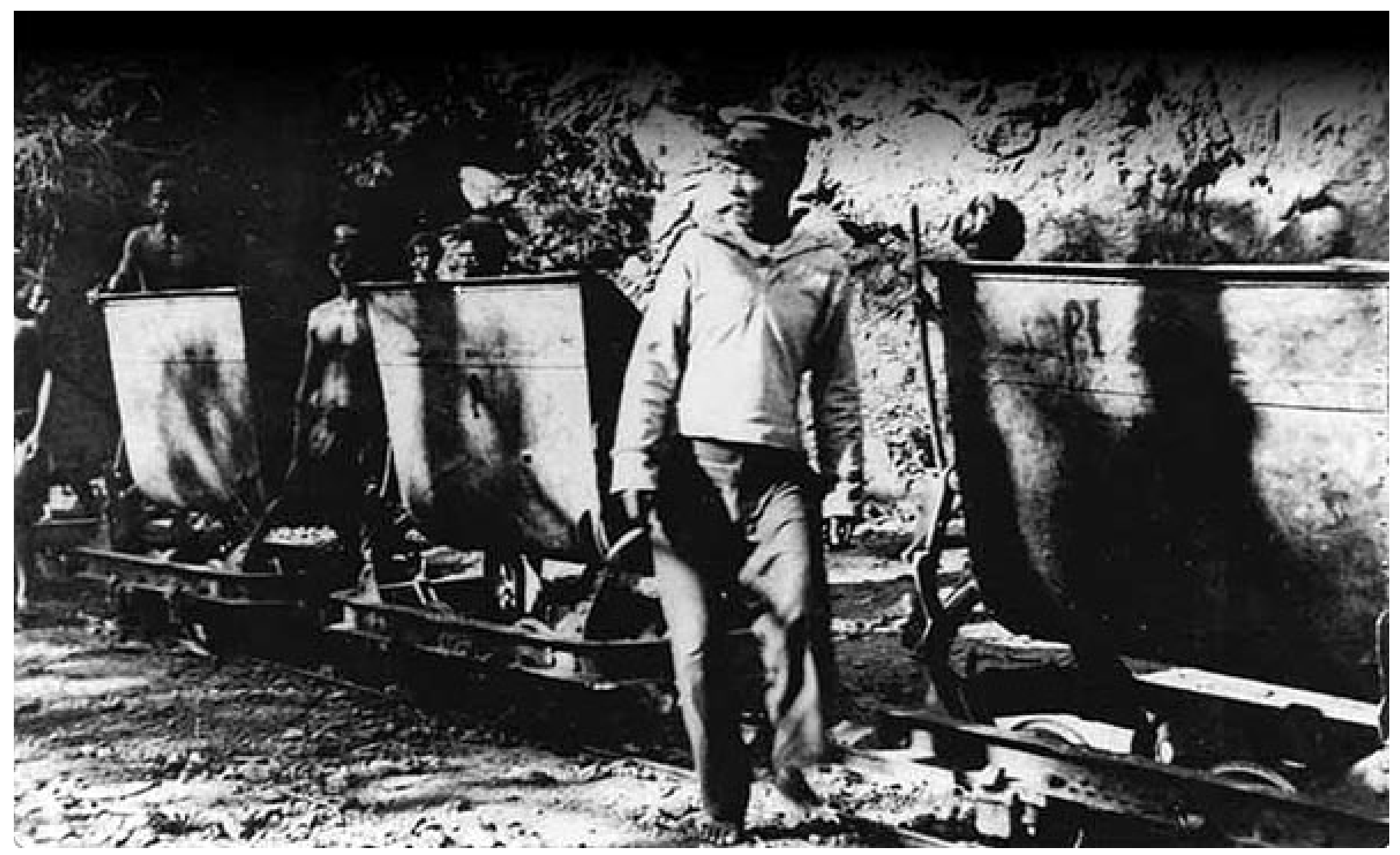

Figure 8. Laborers from Belau and Yap working in the phosphate mines on Ngeaur Island, Belau during World War II. George Fritz Collection, MARC, cited in Pacific Worlds Yap-Ulithi Web site: “Getting There" Pacific Worlds, 2003, http://www.pacificworlds.com/yap/visitors/colony.cfm 
population estimates for either 2003 or 2004 (as available), minerals that occur on the islands, island history, geography, and geologic setting. The second part is an assessment of our state of knowledge concerning the offshore mineral deposit types found, or likely to be found, within each EEZ. This second part concludes with an EEZ mineral summary and a list of selected reference materials. An EEZ map accompanies each section.

Definitions and explanations of the main terms used are presented in appendix 2, and acronyms are explained in appendix 3. All chemical concentrations in the text are listed as weight percents. The geologic time scale used here is that of the International Commission of Stratigraphy (Gradstein, F.M., Ogg, J.G., Smith, A.G., Bleeker, W., and Lourens, L.J., 2004, A new geologic time scale with special reference to Precambrian and Neogene: Episodes, v. 27, no. 2, p. 83100).

Generally we refer to near-term resource potential to mean within the next 25 years, intermediate-term is $25-50$ years, and long-term is more than 50 years. Actual exploitation of resources will depend on other factors. Even though iron-manganese crusts, for example, is listed to have an intermediate-term resource potential for several EEZs, the global market would likely not support mining from more than one or two of those EEZs. Five to ten seamounts could support a 20year mining operation for crusts, which would supply about 15 percent of the annual global need for cobalt. Competing mining operations would probably not be economic for cobalt, although nickel, platinum, and other rare metals might support additional operations if warranted by the global markets for those metals. Technology also plays an important role in the exploitation of deep-sea minerals. For example, the advantage of the exploitation of iron-manganese nodules versus ironmanganese crusts is their relative ease of recovery, whereas the advantage of mining crusts is their occurrence at shallower water depths and their higher contents of rare metals. Several types of phosphorite deposits occur within most of the EEZs considered here. Many phosphorite mines on land will be depleted soon and new sources need to be found. Phosphorite is used in agriculture as a fertilizer and in the food and beverage industries to make the ingredient phosphoric acid. Phosphorite is the commodity that made the island nation of Nauru at one time rich and famous. These and other changing economic, political, security, technological, and land-use issues could significantly affect the realization of the resource potential estimates for the commodities considered here. 


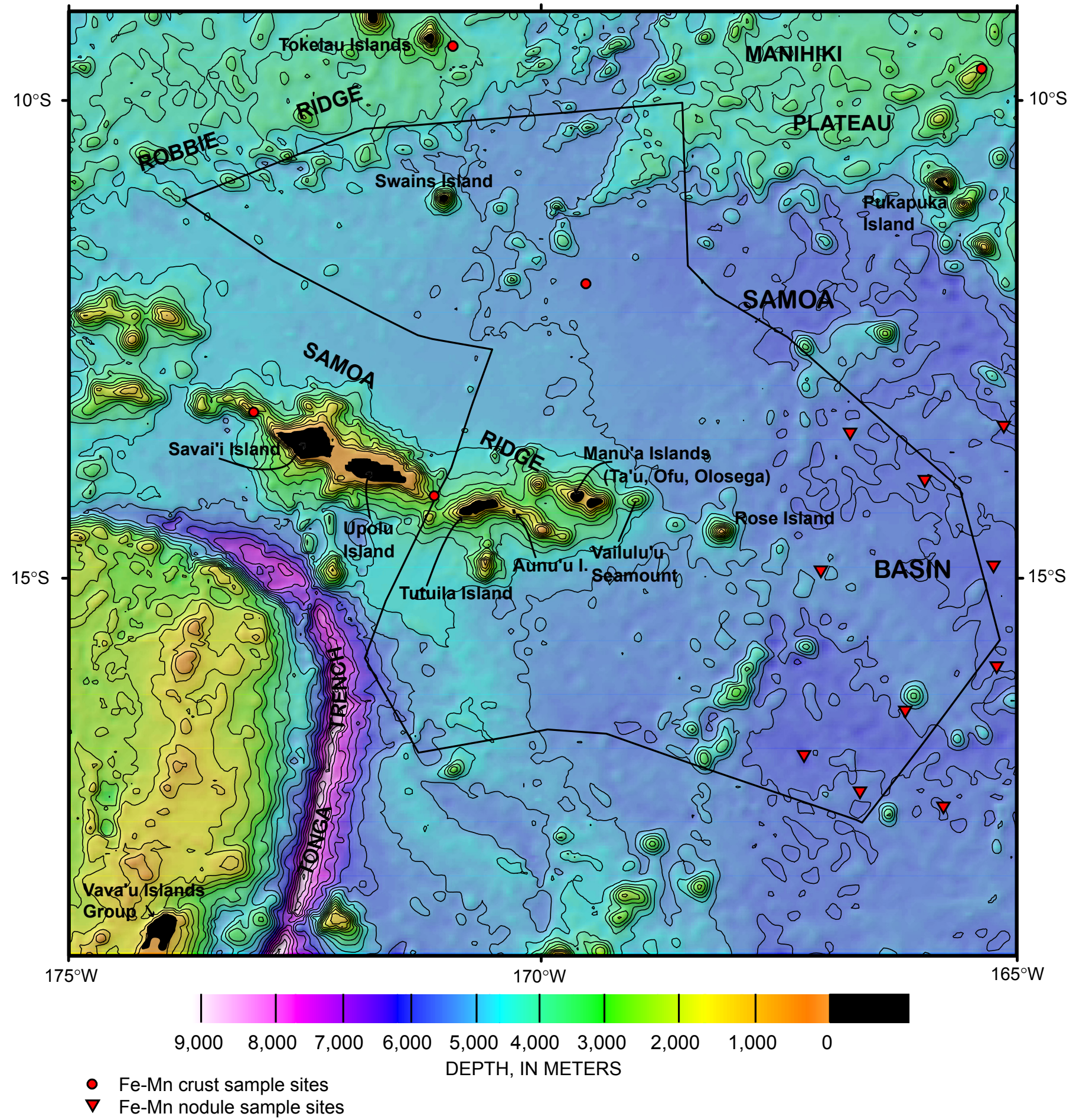

Figure 9. Bathymetric map of the Exclusive Economic Zone (EEZ) of American Samoa ("A" on fig.1); black line shows EEZ boundary. Contour interval is 500 meters. The Tokelau, Cook Islands, Niue/Tonga, and Samoa EEZs border the American Samoa EEZ to the north, east, south, and west, respectively. 


\section{American Samoa}

$\begin{array}{lc}\text { Land area: } & \begin{array}{c}198 \mathrm{~km}^{2}(5 \text { volcanic islands: Tutuila, } \\ \text { 'Aunu'u, Ofu, Olosega, Ta'u; } 2 \\ \text { coral islands: Rose, Swains) }\end{array} \\ \text { EEZ area: } & \begin{array}{r}390,000 \mathrm{~km}^{2} \text { (see fig. 9); location } \\ \text { shown by "A" on figure 1 }\end{array} \\ \begin{array}{l}\text { Political } \\ \text { status: }\end{array} & \begin{array}{c}\text { An unincorporated and unorganized } \\ \text { territory of the United States }\end{array} \\ \text { Population: } & 70,260 \text { (July 2003 estimate) }\end{array}$

Island minerals: Pumice (pumicite), pozzolan

\section{Island History}

American Samoa was settled circa 600 B.C., perhaps by migrants from the west by way of Indonesia, Vanuatu, Fiji, and Tonga (fig. 1). European explorers first visited the islands in the $18^{\text {th }}$ century, the initial visit being by the Dutch explorer Jacob Roggeveen in 1722. Claim disputes among Germany, the United Kingdom, and the United States were settled by the 1899 Treaty of Berlin, in which the United States received the smaller group of eastern islands (Tutuila and Aunu'u), which it formally occupied the next year. The deed of cession was signed on 17 April 1900, and the U.S. Navy took over administrative duties. Ta'u, Ofu, Olosega (the Manu'a Islands), and Rose Island were ceded to the United States in 1904. Swains Island became part of American Samoa in 1925 by a joint resolution of Congress. In 1951, President Truman transferred administration of the islands to the Department of the Interior.

\section{Geography}

American Samoa is the southernmost U.S. territory, centered at about $14^{\circ} \mathrm{S}$ latitude. It is located 3,700 kilometers southwest of Hawai' $i$ and 2,574 kilometers northeast of New Zealand. Tutuila Island possesses an excellent natural deepwater harbor at Pago Pago, which rests at the base of Mt. Matafao, the second highest peak in the territory at $653 \mathrm{~m}$. The highest peak is Lata Mountain at $966 \mathrm{~m}$ on Ta'u Island. Ofu, Olosega, and Ta'u Islands form the Manu'a Islands group (see fig. 9). Swains Island is an atoll without a channel connecting the central lagoon and the open ocean, whereas Rose Island is a typical atoll with free exchange of water between the lagoon and open ocean.

\section{Geologic Setting}

The EEZ of American Samoa encompasses a variety of geologic, morphologic, and tectonic environments (see fig.
9). The sediment-covered, deep-water Samoa Basin occupies most of the eastern half of the EEZ. Seamounts of unknown age penetrate through the sediment in the Samoa Basin, mostly near the southern and northern margins of the EEZ. A small piece of the Manihiki Plateau, a feature about 110 million years old, occupies the northeast corner of the EEZ and includes several seamounts. The eastern end of Samoa Ridge occupies the west-central part of the EEZ. This ridge is composed of the geologically young ( 1.5 million years old to recent) volcanoes that form all the islands within the American Samoa EEZ, except Swains Island. Tutuila Island has a maximum age of about 1.5 million years, and Ta'u Island has had recent volcanic activity. The hot spot (stationary magma chamber deep in the Earth) that created the entire Samoa island chain and ridge (in both Samoa and American Samoa) lies about 45 kilometers east of Ta'u Island (part of the Manu'a Islands) and its active sea-floor manifestation is called Vailulu'u seamount (fig. 9). This seamount is both volcanically and hydrothermally active. Part of Robbie Ridge occupies the northwest corner of the EEZ and includes Swains Island and several seamounts. The age of Robbie Ridge may be similar to that of Manihiki Plateau. The southwest margin of the EEZ is sediment covered and abuts the outer (eastward) margin of the Tonga Trench.

\section{Offshore Mineral Deposits of American Samoa}

The Exclusive Economic Zone (EEZ) of American Samoa contain potential mineral resources that likely include:

- Cobalt-rich iron-manganese crusts on seamounts in the Samoa Basin and on Robbie Ridge and Manihiki Plateau

- Iron-manganese nodules in the deep Samoa Basin

- Phosphorite deposits on seamounts and the flanks of islands

- Insular and lagoonal phosphorite on Rose and Swains Islands

- Native copper deposits on Manihiki Plateau

- Hydrothermal manganese oxide, iron hydroxide, and sulfide deposits on Samoa Ridge

- Shallow-water sand, gravel, and aggregate deposits near the islands

- Shallow- to deep-water precious coral adjacent to the islands and on seamounts

Cobalt-rich iron-manganese crusts likely occur on the several large and many small seamounts located in the Samoa Basin, Manihiki Plateau, and Robbie Ridge. However, the distribution and morphology of the seamounts in the EEZ are poorly known, and the grade and tonnage of the metalrich crusts that may occur on those seamounts are unknown, because no research cruises have been dedicated to their study. Analyses of only two samples of cobalt-rich crusts collected within the EEZ are available (see fig. 9). Neither of those samples is from a location likely to contain the highest potential cobalt-crust resource. The two analyses indicate low contents of total copper plus nickel plus cobalt (1.0 and 0.6 
percent). However, the most economically important of those three metals is cobalt, and it is quite high in one of the samples ( 0.7 percent).

A crust sample collected about 90 kilometers (50 nautical miles) north of the American Samoa EEZ boundary (see fig. 9) was analyzed recently by the USGS and has a similar content of the three metals (total of 1.1 percent). However, this sample has moderately high contents of cobalt and rare metals (tellurium, titanium, tungsten, zirconium) and is relatively thick (45 millimeters; the cut-off thickness for crust mining is estimated to be about 25 to 40 millimeters). A crust sample collected just north of Pukapuka Island in the Cook Islands EEZ (see fig. 9) has a very high combined cobalt/nickel/ copper content of 2.67 percent, with cobalt being dominant at 1.84 percent. These two crusts are likely to be similar in composition to those on seamounts in the northern part of the American Samoa EEZ. Iron-manganese crust deposits may have an intermediate-term resource potential for cobalt and possibly nickel, platinum, and other rare metals. These deposits within the American Samoa EEZ need to be mapped and characterized before their place in the global inventory of crusts can be evaluated.

Iron-manganese nodules likely occur on the sediment surface of the Samoa Basin, where sediment accumulation rates are less than 5 millimeters per 1000 years. However, the distribution, grade, and tonnage of the nodules are not known. Of the 12 sediment samples collected in the American Samoa part of the Samoa Basin, 6 contained nodules along with the sediment (fig. 9). The abundances of nodules in those samples were estimated as low to medium. Nine nodule samples were analyzed from the Samoa Basin, but it was not specified how many of those were from the American Samoa EEZ and how many from the Cook Islands EEZ. The copper plus nickel and cobalt contents are low (with a mean of 0.7 percent and a maximum of 1.1 percent). These values may be typical for nodules in the American Samoa EEZ; however, a survey should be done because nodules in the Penrhyn Basin on the east side of the Manihiki Plateau (Cook Islands EEZ) have been studied in detail and found to be enriched in cobalt. As a result, that area is considered a potential mining target.

The Samoa Basin area adjacent to Samoa Ridge has rapid sediment accumulation rates because of material shed from the ridge; that area will not be prospective, because those sedimentation rates inhibit the growth of nodules. If areas of favorable nodule density and grades can be located, then those nodules would offer an intermediate-term potential resource.

Seamount phosphorite commonly occurs on seamounts along with iron-manganese crusts. The distribution and grade of such deposits in the American Samoa EEZ are unknown. These deposits are typically either small, high-grade deposits or widespread, low-grade deposits. This deep-water deposit type may have a long-term resource potential.

Insular phosphorite may occur on Rose and Swains Islands. A drilling program on the islands and in their lagoons would be required to delineate a potential resource. If significant deposits are found, they could offer an immediate potential resource. However, Rose Island is a U.S. National Wildlife Refuge, and exploration and exploitation there are prohibited.

Native Copper has been recovered from several places on Manihiki Plateau and may occur in the American Samoa EEZ, although that part of the plateau has not been sampled. If native copper does occur in the EEZ, it would probably have a long-term resource potential.

Hydrothermal oxide and sulfide deposits may be found associated with fracture zones and seamounts along the Samoa Ridge, especially where volcanic activity has occurred recently (for example, off Ta'u Island in the Manu'a Island group). The Samoa Ridge has not been explored for such deposits, but the hydrothermal activity that produces them exists in the summit crater of Vailulu'u seamount (fig. 9). That crater should be an important target for exploration. If the deposits are similar to others from volcanically active areas in the Pacific, then hydrothermal manganese and iron oxides will be found to cement volcanogenic sand layers and form stratabound layers within the sediments and rocks.

The manganese deposits may have high contents of nickel, molybdenum, and chromium. However, large deposits of manganese, iron, molybdenum, and chromium occur on the continents, giving these metals only a long-term resource potential if found in the EEZ; large nickel-rich deposits could offer an intermediate-term resource potential. On the other hand, sulfide deposits may have high contents of gold and silver, as well as copper, lead, and zinc. Sulfide deposits may form at and/or below the sea floor, depending on the conditions of the hydrothermal system. If gold- and silver-rich sulfides are found within the American Samoa EEZ, they could offer a near-term resource potential.

Sand and gravel deposits occur in shallow water adjacent to most of the coastline of Tutuila and the Manu'a Islands and is the only potential mineral resource within the EEZ that has been the subject of some exploration. Large tonnage and exploitable deposits occur in Nua-Seetaga Bay and Fagaitua Bay on Tutuila Island. Additional exploitable deposits may also occur on Taema and Nafanua Banks. Smaller offshore sand and gravel deposits and beach sands occur in many other places adjacent to these islands. However, exploitation of the smaller deposits and the beach sands would have to consider environmental issues. Exploitation of numerous onland limestone and volcanic-rock outcrops found in relatively remote areas can provide building aggregate as an alternative to offshore mining. Fluvial aggregate and beach sand deposits are very limited in American Samoa. Nua-Seetaga Bay and Fagaitua Bay offer a near-term resource potential for aggregate and could be mined now if environmental issues can be satisfactorily addressed.

Precious coral is found in shallow to deep water at many places along the Samoa Ridge. A systematic exploration program is needed to determine whether a potential resource exists. Precious coral should also occur on seamounts located throughout the EEZ. Precious coral has an immediate market if a suitable deposit can be located, but caution must be used 
to prevent depletion of the resource beyond the point at which it can be renewed and to ensure that collection methods are selective.

\section{Summary}

The American Samoa EEZ is essentially unexplored for cobalt-rich crusts, nodules, phosphorites, hydrothermal deposits, and precious coral. Although resource evaluations are not possible, environments are present that offer targets for likely mineral occurrences. Sand and gravel, precious coral, insular phosphorite, and gold-rich sulfides may have a near-term resource potential if suitable deposits are located; cobalt-rich crusts, nodules, and copper-lead-zinc sulfides, an intermediateterm resource potential; and seamount phosphorites and native copper deposits, a long-term resource potential. Research cruises dedicated to mineral-deposit studies are required to locate deposits, map their distribution, determine grades and tonnages, and develop criteria to aid in further exploration. In addition, bathymetric maps of the American Samoa EEZ are not adequate for exploration. Parts of the EEZ should be mapped using multi-beam and side-scan sonar techniques.

\section{Selected References}

Cullen, D.J., 1996, Ferromanganese crusts on seamounts in the North Fiji Plateau-Samoa Basin region, in Meylan, M.A., and Glasby, G., eds., Manihiki Plateau, Machias and Capricorn Seamounts, Niue, and Tofua Trough; Results of Tui Cruises: SOPAC Technical Bulletin 10, p. 109-117.

Dingler, J.R., Wolf, S.C., and Carlson, D., 1986, Offshore sand resources along the south shore of Tutuila Island, American Samoa U.S. Geological Survey Open File Report 86-112, $43 \mathrm{p}$.

Dingler, J.R., Carlson, D.V., and Sallenger, A.J., Jr., 1987, Map showing locations and statistical parameters of beach and offshore sand samples, Tutuila Island, American Samoa: U.S. Geological Survey Miscellaneous Field Studies Map 1875 , scale $1: 48,000$.
Exon, N.F., 1981, Manganese nodules in the Cook Islands Region, Southwest Pacific: South Pacific Marine Geological Notes, CCOP/SOPAC, v. 2, no. 4, p. 47-65.

Exon, N.F., 1982, Offshore sediments, phosphorite and manganese nodules in the Samoan Region, southwest Pacific: South Pacific Marine Geological Notes, CCOP/ SOPAC, v. 2, no. 7, p. 103-120.

Hart, S.R., Staudigel, H., Koppers, A.A.P., Blusztajn, J., Baker, E.T., Workman, R., Jackson, M., Hauri, E., Kurz, M., Sims, K., Fornari, D., Saal, A., and Lyons, S., 2000, Vailulu'u undersea volcano; the new Samoa: Geochemistry, Geophysics, Geosystems, v. 1, no. 2000GC000108, 13 p.

Hein, J.R., Koschinsky, A., Halbach, P., Manheim, F.T., Bau, M., Kang, J.-K., and Lubick, N., 1997, Iron and manganese oxide mineralization in the Pacific, in Nicholson, K., Hein, J.R., Bühn, B., and Dasgupta, S., eds., Manganese mineralization; geochemistry and mineralogy of terrestrial and marine deposits: London, Geological Society of London Special Publication 119, p. 123-138.

Hein, J.R., Koschinsky, A., Bau, M., Manheim, F.T., Kang, J.-K., and Roberts, L., 2000, Cobalt-rich ferromanganese crusts in the Pacific, in Cronan, D.S., ed., Handbook of marine mineral deposits: Boca Raton, Florida, CRC Press, p. 239-279.

Palfreyman, W.D., Doutch, H.F., Brathwaite, R.L., Masaharu, K., Piper, D.Z., Swint-Iki, T.R., McCoy, F.W., Sullivan, L.G., Manheim, F.T., and Lane-Bostwick, C.M., 1996, Mineral-resources map of circum-Pacific region, southwest quadrant: U.S. Geological Survey CircumPacific Map Series, 1 sheet, scale 1:10,000,000, with booklet, $66 \mathrm{p}$.

Piper, D.Z., McCoy, F.W., and Swint, T.R., 1985, Manganese nodules, sea floor sediment, and sedimentation rates for the circum-Pacific region: Tulsa, Oklahoma, American Association of Petroleum Geologists, 1 sheet, scale $1: 17,000,000$.

Usui, A., Nishimura, A., and Mita, N., 1993, Composition and growth history of surficial and buried manganese nodules in the Penrhyn Basin, Southwestern Pacific: Marine Geology, v. 114 , p. 133-153. 


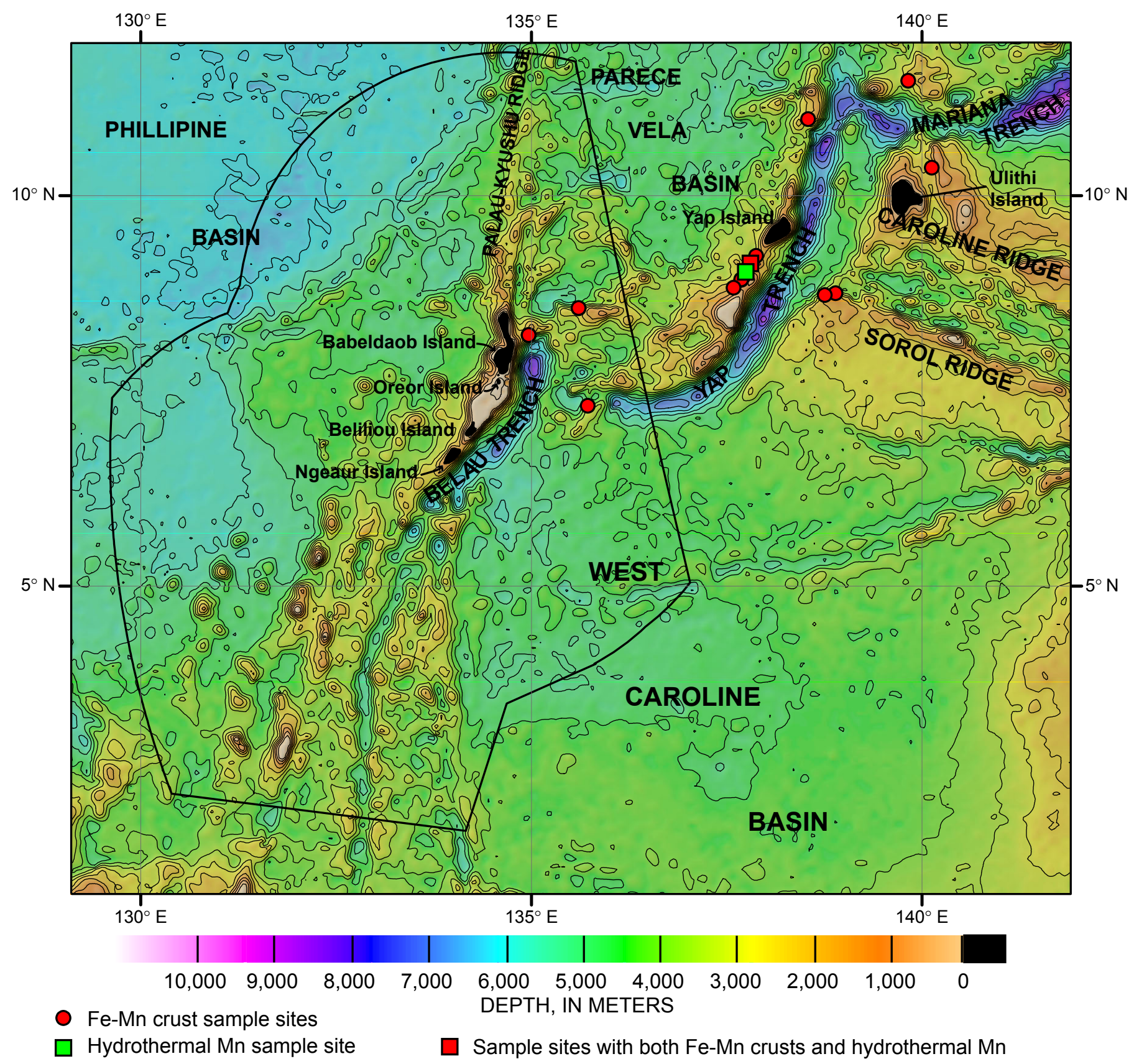

Figure 10. Bathymetric map of the Exclusive Economic Zone (EEZ) of Belau ("B" on fig.1); black line shows EEZ boundary. Contour interval is 500 meters. The Federated States of Micronesia and Indonesia EEZs border the Belau EEZ to the east and south, respectively. 


\section{Republic of Belau (Formerly Palau)}

\author{
Land area: \\ EEZ area: \\ Political status: \\ Population: \\ Island minerals:
}

\author{
$495 \mathrm{~km}^{2}(\sim 300$ islands $)$ \\ $629,000 \mathrm{~km}^{2}$ (see fig. 10); location \\ shown by " $\mathrm{B}$ " on figure 1 \\ Independent nation in free associa- \\ tion with the United States \\ 19,626 (2003 estimate) \\ Aggregate, bauxite, gold, insular \\ phosphate, lignite, kaolinite
}

Note: The Belauan spellings are used for island names throughout this section.

\section{Island History}

Like the rest of Micronesia, Belau was first occupied between 1,000 and 2,000 B.C. by immigrants from the southwest Pacific-Indonesia, Melanesia, and perhaps Polynesia. The first western contact was a rather inauspicious occasion in 1783, when the explorer Captain Henry Wilson of England, aboard the vessel Antelope, ran aground on one of the rock islands located between Oreor (formerly Koror) and Beliliou (formerly Peleliu) Islands. The crew spent several months on the islands rebuilding the ship. The British dominated trade with Belau until 1885, at which time Spain took control of the islands. Spain maintained control until 1899, at which time Belau and the rest of the Caroline and Northern Mariana Islands were sold to Germany, following the defeat of Spain in the Spanish-American War. Germany administered the islands from 1899 to 1914 and developed their natural resources by conscripting native laborers. These laborers mined phosphate on Ngeaur Island (formerly Angaur) and developed coconut plantations.

Japanese forces occupied Belau in 1914 by a mandate from the League of Nations, which recognized the Emperor of Japan as the authority in Micronesia. The Japanese increased development of mining, agriculture, and commercial fishing. They changed the economy from one of subsistence to a market economy. The population swelled to over 40,000, with less than 25 percent being Belauans. Belau became a closed military region in 1938, and campaigns during WWII took place throughout the islands, with major battles on Beliliou, Ngeaur, and Oreor.

The United Nations (U.N.) created the Trust Territory of the Pacific Islands (TTPI) in 1947 and named the United States the administrative authority. Belau was the last TTPI district to reach independence. In the late 1970s, the United States installed a considerable capital improvement program (CIP) with the goal of building major infrastructure projects (airport, dock, roads, and water, power, and sewer systems) in each of the TTPI district centers. Independence from the U.S.-administered U.N. Trusteeship and initiation of the Compact of Free Association with the United States were entered into on 1 October 1994. U.S. and Belau officials had initially signed the compact eight years before that date, on 10 January 1986. It was officially enacted on 14 November 1986. Belau became the $185^{\text {th }}$ member of the U.N. on 15 December 1994.

\section{Geography}

There are about 300 islands in Belau, and nine of them are permanently inhabited. The archipelago extends for about 240 kilometers, but the length of the Belau volcanic arc is about 350 kilometers. The Belau Islands represent the exposed summit of an arcuate submarine ridge, the Belau Ridge (Belau volcanic arc), which is the southernmost arc in a series of arctrench systems that include the Yap, Mariana, and Izu-Bonin systems to the north. The largest island is Babeldaob (Babelthuap), most of which has been inaccessible until recently. A ring road is presently being built around Babeldaob.

The Belau group of islands is encircled by a part-barrier part-fringing reef, except for the northernmost islands, Ngcheangel (formerly Kayangel), and the southernmost island, Ngeaur. The Ngcheangel Islands constitute an atoll, and Ngeaur Island is an uplifted coral platform with a maximum elevation of $56 \mathrm{~m}$. The atoll surrounded by the barrier reef extends south and west of Babeldaob Island. It encloses many smaller islands, which themselves have fringing reefs. The highest elevation in Belau, 287 meters above sea level, is on Babeldaob.

\section{Geologic Setting}

The Belau volcanic arc, of which the Belau Islands are the subaerial expression, began formation just under 40 million years ago. It remained volcanically active until about 20 million years ago, at which time subduction of the Pacific Plate under the Philippine Plate ceased in that region, though it continued further northeast along the Yap and Mariana arcs. It is likely that subduction is currently occurring only at a very slow rate along the Yap Trench, but it is very active along the Mariana Trench. The Belau Arc is now part of the Palau-Kyushu Ridge, which is an extinct volcanic arc (remnant arc), located for the most part in the Philippine Sea backarc basin.

The southeastern part of the Belau EEZ consists of the sediment-covered West Caroline Basin. That basin is part of the West Caroline microplate, which formed by sea-floor spreading about 35 million years ago. The northeastern part of the EEZ includes the westernmost extent of the Yap Trench and Arc and the southwesternmost part of the Parece Vela Basin, part of the Yap-Mariana back-arc basin. The Parece Vela Basin crust began formation about 40 million years ago. The central part of the Belau EEZ is occupied by the Belau arc-trench system and the northern extension of the arc into the Palau-Kyushu Ridge, where volcanism ended about 25 million years ago. The western third of the EEZ consists of 
the sediment-covered West Philippine Basin, which began to form by sea-floor spreading about 60 million years ago. Numerous seamounts penetrate through the sediment in that basin.

The oldest rocks exposed on the Belau Islands are of volcanic origin and are related to subduction and arc formation. Those rocks are overlain in places by carbonate reef limestones of Pliocene through Holocene ages (less than 5 million years old). Similar rocks largely make up the uplifted carbonate platform islands of Beliliou and Ngeaur. Bauxite (aluminum ore) was mined on Babeldaob Island from two (Ngardmau, Ngeremlengui) of the dozens of prospects identified there. Mining ceased during World War II after a total of 369,227 metric tones, averaging 52 percent aluminum oxide $\left(\mathrm{Al}_{2} \mathrm{O}_{3}\right)$, was produced between 1938 and 1944. About 2 million tonnes of proved reserves of 30 percent $\mathrm{Al}_{2} \mathrm{O}_{3}$ still exists, as well as much more lower grade ore. Phosphate was mined in Belau and is discussed below. At the Rois Malk epithermal gold deposit on southeast Babeldaob Island, volcanic rocks are overlain in fault contact by a sequence of poorly consolidated shale, shaly siltstone, and pebble conglomerate. Locally, these rocks are highly enriched in organic matter, constituting lignite (coal) deposits. The lignite was briefly mined during World War II along with interbedded layers of kaolinite (white clay) that was used for ceramics.

\section{Offshore Mineral Deposits of Belau}

Despite the occurrence of onshore phosphorite on Ngeaur and gold deposits on Babeldaob, cobalt-rich iron-manganese crusts, seamount phosphorites, and other possible offshore deposits have been little sampled and studied. The Belau EEZ shares its northeastern boundary with the Federated States of Micronesia, its southern boundary with Indonesia, and part of the western boundary with the Philippines. Mineral deposits that do, or should, occur within the EEZ include:

- Cobalt-rich iron-manganese crusts associated with seamounts and ridges

- Phosphorite deposits on seamounts and ridges

- Insular and lagoonal phosphorite on Ngeaur, Beliliou, Mecherchar, and other islands

- Hydrothermal iron and manganese deposits on seamounts and ridges

- Epithermal gold along the Belau Arc

- Shallow-water sand and gravel (aggregate) around islands

- Shallow- to deep-water precious coral on seamounts, ridges, and islands slopes

Cobalt-rich iron-manganese crusts have been relatively extensively studied along the Palau-Kyushu Ridge, but only sparingly elsewhere within the Belau EEZ. The Palau-Kyushu Ridge contains widespread crust deposits with relatively low contents of cobalt, nickel, and platinum and moderate amounts of copper. Three crust samples from the Belau EEZ yielded average cobalt, copper, and nickel contents of 0.29 percent, 0.11 percent, and 0.28 percent, respectively. On West Caroline Basin seamounts, crusts tend to be thin, averaging about 10 millimeters and having a maximum thickness of about 40 millimeters. The many seamounts in the southern third of the EEZ have not been sampled. The potential for crust resources in the Belau EEZ is probably low, but data are few, warranting an exploration survey. Iron-manganese nodules are not known to occur in the Belau EEZ. Their paucity there can be attributed to high sediment accumulation rates on the abyssal sea floor.

Phosphorite deposits are widespread on seamounts and ridges throughout the Palau-Kyushu Ridge and seamounts in the West Caroline Basin. They occur in the same places as the iron-manganese crusts. The deposits are high grade and cover large areas, but individual deposits are generally small. Additional exploration is warranted, even though this deposit type is likely to have only a long-term resource potential.

Insular phosphorite was mined on Ngeaur, Beliliou, and Mecherchar (Eil Malk) Islands, and many prospects occur on those islands and also on Ngeruktabel (Urukthapel), Tobi, Pulo Anna, and Sonsorol. Phosphate was discovered on Ngeaur and Beliliou in 1903. Exploitation started during German occupation in 1909 on Ngeaur and during Japanese occupation in 1935 on Beliliou. Between 1909 and 1951, about 3,200,000 metric tonnes of phosphate was mined on Ngeaur. Mining decreased after 1951 and was suspended in 1955. Reserves on Ngeaur are estimated to be about 500,000 to 700,000 tonnes of 37 percent $\mathrm{P}_{2} \mathrm{O}_{5}$. Reserves on Mecherchar are estimated at 300,000 to 500,000 tonnes containing $\geq 25$ percent $\mathrm{P}_{2} \mathrm{O}_{5}$; about 4,000 tonnes was previously mined on that island. Reserves on Beliliou are estimated at 155,000 tonnes of 32 percent $\mathrm{P}_{2} \mathrm{O}_{5}$; 145,800 metric tonnes was previously mined there. Additional estimated reserves are present on Tobi (120,000 tonnes of 30 percent $\mathrm{P}_{2} \mathrm{O}_{5}$ ), Pulo Anna (5,000 tonnes of 29 percent $\mathrm{P}_{2} \mathrm{O}_{5}$ ), and Sonsorol (20,000 tonnes of 30 percent $\left.\mathrm{P}_{2} \mathrm{O}_{5}\right)$.

The deposits mined in the early to middle 1900 s were high grade. Production reached a maximum in the late 1930s, when slightly more than 142,200 metric tonnes was shipped to Japan annually. The potential for additional insular and lagoonal phosphorites is unknown, but is likely to be small. Still, a drilling program in the southernmost region of the lagoon in the vicinity of Beliliou Island might identify additional resources.

Epithermal gold deposits hosted in quartz veins occur in a small area of southeast Babeldaob Island, at Rois Malk. Gold concentrations are as high as 15 grams per ton, but average less than 1 gram per ton. One dredge haul seaward of Babeldaob Island collected vein quartz-epidote rocks with very small enrichments of gold. Still, the recovery of such vein quartz warrants a greater investigation. Location of deposits of sufficient tonnage and grade would have a short-term resource potential.

Hydrothermal iron and manganese deposits have been identified on Babeldaob Island. They likely also occur on submerged banks and slopes scattered throughout the region. A research program will be required to evaluate their resource 
potential, but they are likely to have only a long-term resource potential.

Shallow-water sand and gravel that can be used for construction aggregate consists of coral and shell. Past construction on the islands has used hard-packed coral gravel, cement, and volcanic rock aggregate. Locating lagoonal and nearshore sand and gravel deposits might have immediate economic importance for local construction. However, outcrops of volcanic rock on Babeldaob and Oreor Islands offer a better alternative to mining aggregate offshore.

Shallow- to deep-water precious corals occur in the lagoons and on island slopes, seamounts, and ridges in the Belau EEZ. Small operations have mined black and red coral in Belau for local use. A survey for black coral (Antipathes dichotoma) between Babeldaob and Beliliou Islands found many occurrences, both inside and outside the barrier reef. Samples outside the reef are larger, have more branches, and cover a larger depth range, but those inside the reef are easier to collect. It has been estimated that the maximum sustained yield of black coral is about 635 kilograms per year. Fern black coral (Antipathes ulex) has also been found in Belau waters and when polished reveals streaks of gold that give it the appearance of gold corals found in Hawai'i. Fern black coral is rather rare and therefore has little resource potential.

High quality Corallium clatius, precious pink coral, has been found at a number of locations between Beliliou and Ngeaur Islands. However, very little is known about its distribution. Melitodidae (M. albitincta and M. Mopsella sp.) red coral has also been found in Belau waters. This type of coral is less valuable than pink coral because it has a duller luster and is softer. Nonetheless, it has been collected in Belau and used locally in making jewelry and for ornamental displays. Bamboo coral has been collected in deep water in many dredge hauls that sampled Fe-Mn crusts and phosphorite throughout this region of the Pacific. However, its distribution, abundance, and resource potential are unknown.

Belau appears to have numerous potential sites for the harvesting of precious coral. A systematic exploration program is needed to delineate this valuable resource. If important deposits can be located, they would have an immediate economic market. It is, however, essential to harvest the coral at a rate that would not deplete the stocks and with adequate resource conservation measures.

\section{Summary}

In the Belau EEZ, aggregate and precious coral can have an immediate economic impact if significant deposits and markets are found. Insular/lagoonal phosphorite and epithermal gold deposits could offer short- to intermediate-term resource potential if significant deposits are found. Cobalt-rich crusts should occur throughout the EEZ, but have limited resource potential because of low grades and tonnages. The other deposit types represent long-term or unknown resource potentials. Reconnaissance cruises dedicated to understanding the distribution, grade, and tonnage of all the potential resources are recommended. Only small parts of the EEZ have been mapped using multibeam bathymetric techniques and much larger parts need to be mapped to undertake viable exploration programs.

\section{Selected References}

Burnett, W.C., and Lee, A.I.N., 1980, The phosphate supply system in the Pacific region: GeoJournal, v. 4, p. 423-436.

Grigg, R.W., 1975, The commercial potential of precious corals in the western Caroline Islands, Micronesia: Sea Grant Technical Report UNIHI-SEAGRANT-AR-75-03, 14 p.

Hawkins, J.W., Bloomer, S.H., Evans, C.A., and Melchior, J.T., 1984, Evolution of intra-oceanic arc-trench systems: Tectonophysics, v. 102, p. 175-205.

Hein, J.R., 2004, Cobalt-rich ferromanganese crusts; global distribution, composition, origin and research activities, in Minerals other than polymetallic nodules of the international seabed area: Kingston, Jamaica, International Seabed Authority, Proceedings of a workshop held on 26-30 June 2000, v. 1, p. 188-256.

Hein, J.R., Ahn, J-H., Wong, J.C., Kang, J.-K., and others, 1992, Geology, geophysics, geochemistry, and deep-sea mineral deposits, Federated States of Micronesia; KORDIUSGS R.V. Farnella Cruise F11-90-CP: U.S. Geological Survey Open-File Report 92-218, 191 p.

Hein, J.R., Koschinsky, A., Bau, M., Manheim, F.T., Kang, J.-K., and Roberts, L., 2000, Cobalt-rich ferromanganese crusts in the Pacific, in Cronan, D.S., ed., Handbook of marine mineral deposits: Boca Raton, Florida, CRC Press, p. 239-279.

Hein, J.R., Koschinsky, A., Halbach, P., Manheim, F.T., Bau, M., Kang, J.-K., and Lubick, N., L., 1997, Iron and manganese oxide mineralization in the Pacific, in Nicholson, K., Hein, J.R., Bühn, B., and Dasgupta, S., eds., Manganese mineralization; geochemistry and mineralogy of terrestrial and marine deposits: Geological Society of London Special Publication 119, p. 123-138.

Hein, J.R., Moon, J.-W., Lee, K.-Y., Dowling, J.S., Kim, K.-H., Burrows, M., Park, S.H., Choi, Y.-J., Schuetze, A.A., Jung, H.S., Kin, H.-S., Lee, G.C., Park, C.-K., Son, S.K., and Park, C.Y., 1999, Co-rich Fe-Mn crusts from the Marshall Islands (Leg 1) and hydrothermal and hydrogenetic Fe-Mn deposits from Micronesia (Leg 2), KODOS 98-3 cruise, West Pacific: U.S. Geological Survey Open-File Report 99-412, 63 p.

Irving, E.M., 1950, Phosphate deposits of Angaur Island, Palau Islands: Report to the Military Geology Branch, U.S. Geological Survey, for the Intelligence Division, Office of the Engineer, General Headquarters, Far East Command, 99 p.

Miller, W.R., Rytuba, J.J., Arnold, M.A., and Vercoutere, T.L., 1989, Investigation of the Rois Malk epithermal gold system, Republic of Palau: U.S. Geological Survey Bulletin $1872,85 \mathrm{p}$.

Stoddart, D.R., and Scoffin, T.P., 1983, Phosphate rock on 
coral reef islands, in Goudie, A.S., and Pye, K., eds., Chemical sediments and geomorphology: London,

Academic Press, p. 369-400.

U.S. Army, Far East Command, 1956, Military geology of Palau Islands, Caroline Islands: Engineer intelligence dossier strategic study, Carolines, subfile 19, Analysis of the natural environment, $285 \mathrm{p}$.
Usui, A., and Someya, M., 1997, Distribution and composition of hydrogenetic and hydrothermal manganese deposits in the northwest Pacific, in Nicholson, K., Hein, J.R., Bühn, B., and Dasgupta, S., eds., Manganese mineralization; geochemistry and mineralogy of terrestrial and marine deposits: Geological Society of London Special Publication 119, p. 177-198. 
(Section on Guam begins on following pages.) 

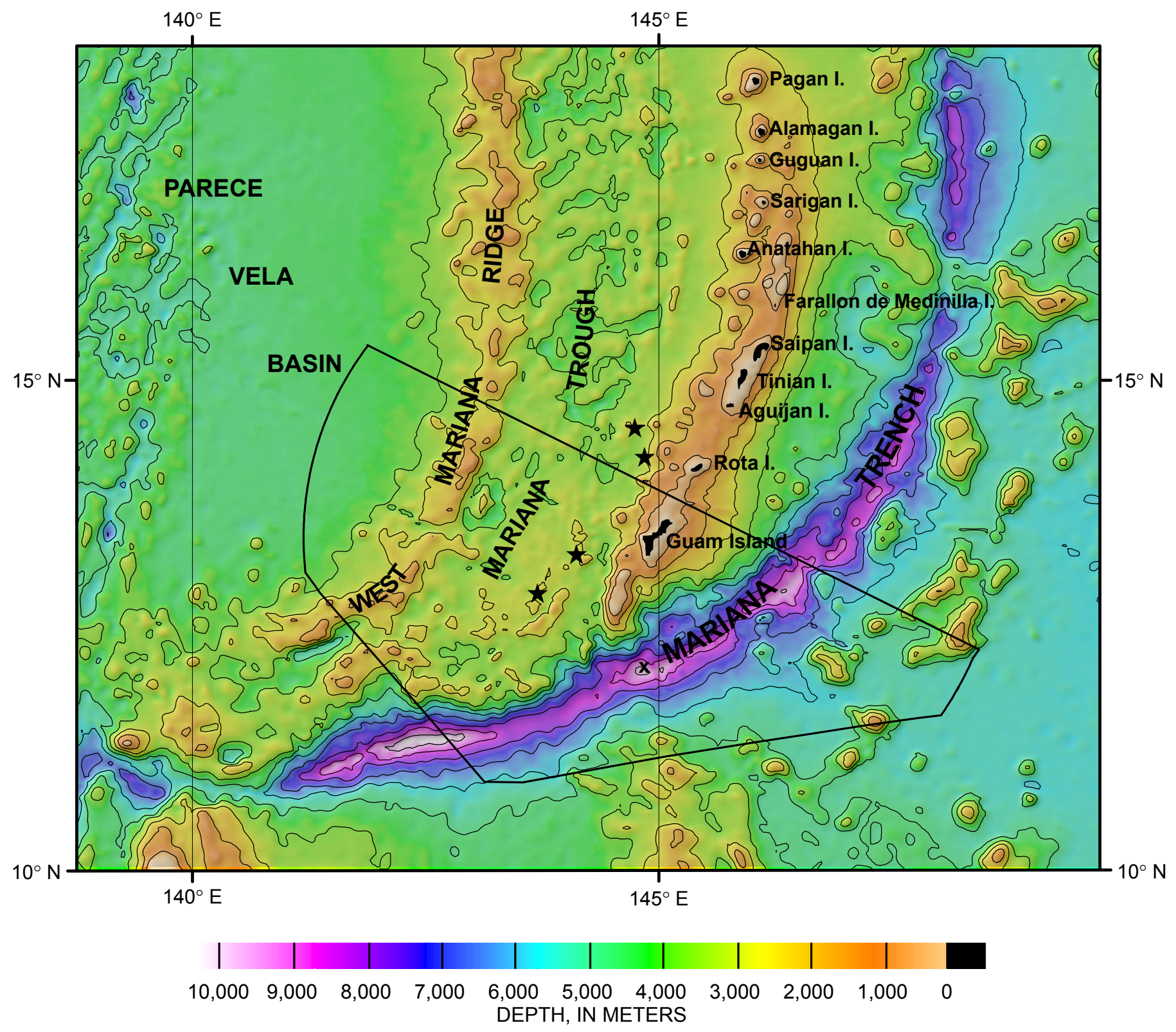

Hydrothermal vent sites

Figure 11. Bathymetric map of the Exclusive Economic Zone (EEZ) of Guam ("C" on fig.1); black line shows EEZ boundary. Contour interval is 1,000 meters. The Federated States of Micronesia and the Commonwealth of the Northern Mariana Islands EEZs border the Guam EEZ to the south and north, respectively. Challenger Deep, (the greatest ocean depth (10,924 meters), is marked with an X. 


\section{Guam}

\section{Land area: EEZ area:}

Political status:

Population: Island minerals:

\section{Island History}

The Chamorro people first occupied Guam and may have migrated there from the Malay Archipelago. In 1521, Ferdinand Magellan was the first Westerner to visit Guam. Miguel Lopez Legaspi claimed Guam and several Mariana Islands for Spain in 1565; colonization began a few years later but was not well established until 1688. Most of the native Chamorro population died from disease and war during the following three centuries. U.S. forces took Guam in 1898 during the Spanish-American War, and it was ceded to the United States by Spain that year. Guam was under administration by the U.S. Navy until 1941, when it was captured by the Japanese. It was retaken by the United States three years later, and the U.S. Navy then renewed administration of the island.

The Guam Organic Act of 1950 conferred U.S. citizenship on the people of Guam and established local self government. At that time, the Department of the Interior took over administrative responsibility for Guam. Military installations on Guam are some of the most strategically important in the Pacific region. As the westernmost U.S. Territory, Guam is west of the International Date Line, and is one day ahead of the United States. Hence the slogan: "Where America's Day Begins."

\section{Geography}

Guam is the largest island in Micronesia and is the southernmost of the Mariana Islands. The northern half of Guam is composed of a relatively flat coralline limestone plateau about $260 \mathrm{~m}$ above sea level, whereas the southern part is mountainous volcanic terrain with elevations up to $406 \mathrm{~m}$ (Mount Lamlam). Guam is largely surrounded by a fringing reef, but at the southern tip of Guam, a barrier reef and Cocos Island enclose Cocos Lagoon. Apra Harbor, located along the westcentral coast, is a large lagoon bounded by Cabras Island on the north and the Orote Peninsula on the south.

\section{Geologic Setting}

Guam is in the southernmost part of the volcanic arc that includes the Mariana Islands and many associated seamounts, several of which are volcanically active. The north-central part of the Guam EEZ is occupied by this volcanic arc (see fig. 11). The Mariana Arc started to develop about 40 million years ago by subduction of the Pacific Ocean crust underneath the Philippine Sea crust. Volcanic activity has occurred at various places along the arc since that time. To the south and southeast of Guam is the Mariana Trench, which has its deepest expression within the Guam EEZ - in fact, this is the deepest location in the global ocean. The trench is partly filled with sediment.

East of the Mariana Trench is the sediment-covered Pacific Ocean abyssal plain with several large Cretaceous ( $>65$ million years old) seamounts that protrude through the sediment. The underlying crust in this area is Jurassic in age (>142 million years old) and is the oldest part of the Pacific Ocean crust. West of the Guam-Mariana Arc is the mostly sediment-covered Philippine Sea floor (a back-arc basin) with numerous seamounts, ridges, and basins that are less than 20 million years old. In the part immediately west of the Mariana Arc is the Mariana Trough, an active back-arc spreading ridge. The West Mariana Ridge is a remnant (inactive) volcanic arc that separates the Mariana Trough from the Parece Vela Basin abyssal plain farther to the west, in the northwesternmost part of the Guam EEZ.

\section{Offshore Mineral Deposits of Guam}

The EEZ of Guam encompasses a variety of geologic, morphologic, and tectonic environments. Mineral deposits within these environments represent near- to long-term potential mineral resources that likely include:

\section{- Cobalt-rich iron-manganese crusts on Cretaceous} seamounts

- Iron-manganese nodules on abyssal plains

- Phosphorite deposits on Cretaceous seamounts

- Epithermal gold deposits on the active volcanic arc

- Hydrothermal manganese- and iron-oxide deposits on the active arc and back-arc

- Hydrothermal polymetallic sulfide/sulfate deposits on the active arc and back-arc

- Sand and gravel (aggregate) in nearshore environments

- Precious coral on the flanks of Guam and flanks and summit of seamounts

Cobalt-rich iron-manganese crusts likely are present east of the Mariana Trench on two large and many small Cretaceous seamount complexes located on Pacific Ocean crust. The distribution and morphology of Cretaceous seamounts in that region are poorly known, as are the distribution, grade, and tonnage of crusts on those seamounts. Data for crusts from nearby seamounts indicate that crusts on Cretaceous seamounts within the Guam EEZ are likely to be thick and have high concentrations of cobalt, nickel, and especially platinum. These deposits may represent an intermediate-term resource 
potential for cobalt, titanium, cerium, nickel, platinum, and other rare-earth elements and metals. Iron-manganese crusts recovered from the Guam sector of the Mariana Arc and West Mariana remnant arc are too thin and have cobalt contents too low to be considered economically viable in the foreseeable future. A research cruise is required to sample and map the distribution of crusts on the Cretaceous seamounts in the Guam EEZ before a resource evaluation of those crusts can be made.

Iron-manganese nodules have been photographed on the abyssal plain east of Guam and also west of Guam, on the deepest parts of the Philippine Sea floor. Judging from these few photographic stations, nodule coverage is apparently low. However, not enough data exist to determine nodule distribution, grade, or tonnage. A research cruise is required to sample and map the distribution of nodules in the Guam EEZ before a resource evaluation can be made.

Phosphorite should occur on the same Cretaceous seamounts as the iron-manganese crusts. However, the distribution and grade are not known. These deposits are typically either small, high-grade deposits or more widespread, lowgrade deposits. This deep-water deposit type may have a longterm resource potential.

Gold deposits of epithermal origin are known to occur on islands in the Yap and Palau volcanic arcs to the south and southwest of Guam. Favorable geologic offshore sites for epithermal gold are probable along the intersections of faults and fracture zones and along the Guam-Mariana Arc in submerged calderas. Exploration will be required to delineate potential sites for epithermal gold deposits. If epithermal gold does occur offshore in deep water, it would offer an intermediateterm resource potential.

Manganese oxide of hydrothermal origin is known to occur extensively along the Mariana volcanic arc, along the spreading axis of the Mariana Trough, and on the West Mariana Ridge. Manganese oxide cements sediments and forms stratabound layers within the sediments and rocks. In places, the manganese deposits have high contents of one or more of the metals copper, nickel, molybdenum, zinc, and chromium. Because large deposits of these metals are currently available on the continents, this deposit type offers only a long-term resource potential. However, it may be found that other metals of economic importance are enriched in the manganese-oxide deposits in volcanic arcs; chromium-rich deposits were only recently discovered in the Yap Arc. These low-temperature hydrothermal deposits may also be indicators of nearby hightemperature polymetallic sulfide deposits.

Polymetallic sulfides, sulfates, and sulfur of hydrothermal origin have been found north of Guam at several sites along the active Mariana Arc. Hydrothermal activity at seven additional sites have been reported, but they have not been surveyed for polymetallic sulfide deposits. A large gold-rich deposit was found in 1999 in a volcanic crater (caldera) in the Izu-Bonin Arc, which is a continuation of the Mariana Arc to the north. These deposits and hydrothermal sites are outside the Guam EEZ, the closest being 37 kilometers north of the EEZ boundary.
Two recently discovered hydrothermal sites with associated sulfides have been found south of Guam within its EEZ (fig. 11). One site is located along the spreading axis of the Mariana Trough and the other is a seamount located along an offset of the southern most part of the Mariana Arc. These deposits have been discovered only recently and have not yet been analyzed for gold, silver, and base-metal contents. Polymetallic sulfides from the Okinawa trough back-arc basin located to the west of the Mariana Arc have high gold and silver contents. Polymetallic sulfide deposits have been explored for in the Guam EEZ in a reconnaissance fashion, and more sites similar to the two recently discovered are likely to exist in the central region of the EEZ. If gold- and silverrich polymetallic sulfides are found within the Guam EEZ, they could offer a near-term resource potential.

Sand and gravel deposits occur in shallow water adjacent to most of the Guam coastline. Large and exploitable deposits occur in Cocos Lagoon to the south of Guam and in Apra Harbor. Exploitation of these or smaller deposits along the coast would have to address environmental concerns. Numerous on-land limestone and volcanic rock outcrops in relatively remote areas offer a viable alternative source for building aggregate. Beach sand also provides a potential source for building aggregate, but again its exploitation raises environmental issues. Fluvial aggregate and beach-placer deposits are very limited on Guam. Sand and gravel in Cocos Lagoon and Apra Harbor offer a near-term resource potential.

Precious coral is found at shallow to intermediate water depths at many places around Guam. Surveys for black and $\mathrm{red} /$ pink coral were carried out in 1975, but no commercial grade deposits were indicated on the basis of the few samples collected. However, the deeper water areas $(>400 \mathrm{~m})$ around Guam and seamounts east of the Mariana Trench have not been surveyed; promising targets occur to depths of $1,500 \mathrm{~m}$ in both areas. Regulations are already in place concerning the exploitation of this resource. Precious coral has an immediate economic market, but exploitation must not deplete the resource beyond the point at which it can renew itself.

\section{Summary}

Several reconnaissance cruises have located and investigated hydrothermal sites within the Guam EEZ for scientific purposes. Reconnaissance exploration for sand and gravel and for precious coral has also taken place. Aggregate, precious coral, and gold- and silver-rich hydrothermal polymetallic sulfides have an immediate economic market. Cobalt-rich crusts may have an intermediate-term resource potential, but a survey of the Cretaceous seamounts in the southeastern part of the EEZ must be carried out. Iron-manganese nodules, hydrothermal manganese, base-metal hydrothermal polymetallic sulfides, phosphorite, and epithermal gold offer intermediate to long-term resource potentials. Available bathymetric maps of the Guam EEZ are not good enough for exploration purposes, and the EEZ should be mapped using multibeam bathymetric and sidescan sonar techniques. 


\section{Select References}

Grigg, R.W., and Eldredge, L.G., 1975, The commercial potential of precious corals in Micronesia; Part 1, the Mariana Islands: University of Guam, Sea Grant Publication, UGSG-75-01.

Hein, J.R., Fleishman, C.L., Morgenson, L.A., Bloomer, S.H., and Stern, R.J., 1987, Submarine ferromanganese deposits from the Mariana and Volcano volcanic arcs, West Pacific: U.S. Geological Survey Open-File Report 87-281, 67 p.

Hein, J.R., Koschinsky, A., Halbach, P., Manheim, F.T., Bau, M., Kang, J.-K., and Lubick, N., 1997, Iron and manganese oxide mineralization in the Pacific, in Nicholson, K., Hein, J.R., Bühn, B., and Dasgupta, S., eds., Manganese mineralization; geochemistry and mineralogy of terrestrial and marine deposits: Geological Society of London Special Publication No. 119, p. 123-138.

Hein, J.R., Koschinsky, A., Bau, M., Manheim, F.T., Kang, J.-K., and Roberts, L., 2000, Cobalt-rich ferromanganese crusts in the Pacific, in Cronan, D.S., ed., Handbook of marine mineral deposits: Boca Raton, Florida, CRC Press, p. 239-279.

National Oceanic and Atmospheric Administration, Submarine ring of fire 2004-Mariana Arc: at http://oceanexplorer. noaa.gov/explorations/04fire/welcome.html, accessed
September 2005

Palfreyman, W.D., Doutch, H.F., Brathwaite, R.L., Masaharu, K., Piper, D.Z., Swint-Iki, T.R., McCoy, F.W., Sullivan, L.G., Manheim, F.T., and Lane-Bostwick, C.M., 1996, Mineral-resources map of circum-Pacific region, southwest quadrant: U.S. Geological Survey Circum-Pacific Map Series, 1 sheet, scale 1:10,000,000, with booklet, $66 \mathrm{p}$.

Piper, D.Z., McCoy, F.W., and Swint, T.R.,1985, Manganese nodules, sea floor sediment, and sedimentation rates for the circum-Pacific region: Tulsa, Oklahoma, American Association of Petroleum Geologists, 1 sheet, scale $1: 17,000,000$.

Schulz, M.S., and Hein, J.R., 1991, Petrography and chemistry of hydrothermal manganese oxyhydroxides from the Mariana and Izu-Bonin volcanic arcs, West Pacific: U.S. Geological Survey Open-File Report 91-557, 80 p.

Tracey, J.I., Jr., Schlanger, S.O., Stark, J.T., Doan, D.B., and May, H.G., 1964, General geology of Guam: U.S. Geological Survey Professional Paper 403-A, 104 p.

Usui, A., and Someya, M., 1997, Distribution and composition of marine hydrogenetic and hydrothermal manganese deposits in the northwest Pacific, in Nicholson, K., Hein, J.R., Bühn, B., and Dasgupta, S., eds., Manganese mineralization; geochemistry and mineralogy of terrestrial and marine deposits: Geological Society of London Special Publication No. 119, London, p. 177-198. 


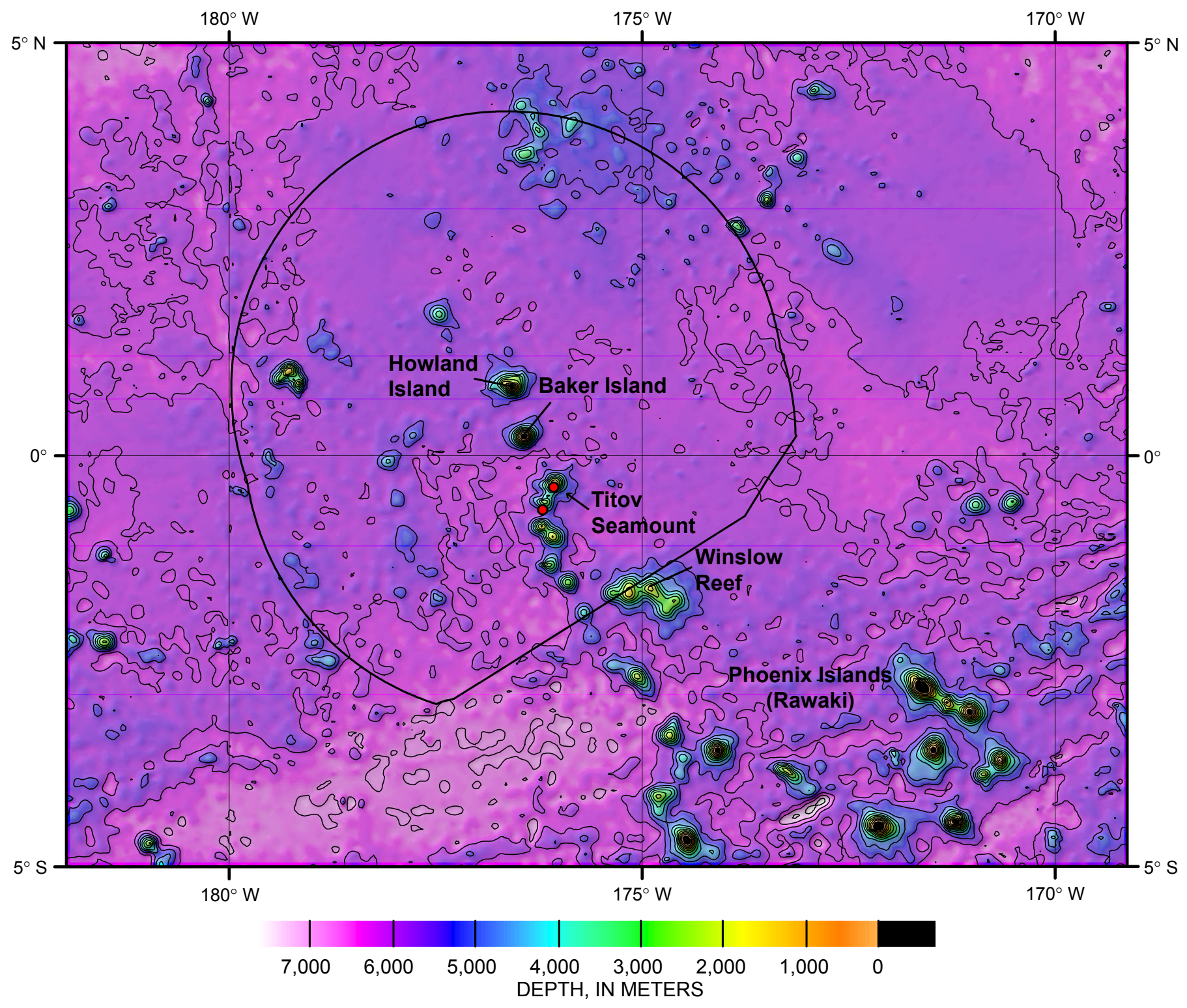

- Fe-Mn crust sample sites

Figure 12. Bathymetric map of the Exclusive Economic Zone (EEZ) of Howland and Baker Islands (“D” on fig.1); black line shows EEZ boundary. Contour interval is $\mathbf{5 0 0}$ meters. The Kiribati EEZ borders the Howland and Baker Islands EEZ to the southeast. 


\section{Howland and Baker Islands}

$\begin{array}{ll}\text { Land area: } & \begin{array}{l}1.6 \mathrm{~km}^{2} \text { (Howland), } 1.4 \mathrm{~km}^{2} \\ (\text { Baker })\end{array} \\ \text { EEZ area: } & 425,700 \mathrm{~km}^{2} \text { (see fig. 12); } \\ & \text { location shown by "D" on } \\ & \text { figure 1 } \\ \text { Political status: } & \begin{array}{l}\text { Unincorporated territory of } \\ \text { the United States }\end{array} \\ \text { Population: } & \text { Uninhabited } \\ \text { Island minerals: } & \text { Phosphorite/guano }\end{array}$

\section{Island History}

Captain George B. Worth on the U.S. whaling ship Oeno discovered these islands in 1822 . They were visited subsequently in 1828 by Captain Daniel McKenzie of the U.S. whaler Minerva Smyth, in 1832 and 1839 by Michael Baker of the whaler Gideon Howland, and in 1842 by Captain George E. Netcher of the U.S. whaler Isabella. Alfred G. Benson and Charles H. Judd took formal possession of the islands (as well as Jarvis Island) in 1857 in the name of the American Guano Company of New York. Rich guano deposits were mined from 1850 to 1891 and in 1857 the United States claimed the islands on the basis of the Guano Act of August 18, 1856. The Guano Act stated that "when any citizen of the United States discovers a guano deposit on any island, rock, or key, not within the lawful jurisdiction of any other government, and takes peaceable possession thereof, and occupies the same island, rock, or key, it appertains to the United States." In the later part of the $19^{\text {th }}$ century, the guano industry gradually disappeared on Howland and Baker Islands. The islands were then barren outposts until the era of aviation began in the 1930s. The United States reasserted its claim to the islands in 1934. A few colonists occupied the islands in 1936, but they were removed following Japanese attacks on the islands in 1942. U.S. military personnel occupied the islands during World War II. The islands have remained unoccupied since that time, but they are visited annually by U.S. Fish and Wildlife personnel because the islands are a National Wildlife Refuge.

Howland Island played a role in the tragic disappearance of Amelia Earhart and Fred J. Noonan during their around-theworld flight in 1937. They left Lae, New Guinea, on July 2, 1937, headed for Howland Island, but were never seen again. Numerous speculations have been put forward as to their fate. The Amelia Earhart lighthouse on Howland Island was partly destroyed during World War II, but it was later rebuilt in her memory.

\section{Geography}

Howland and Baker Islands lie just north of the equator, about 3,056 kilometers southwest of Hawai'i. They are sepa- rated by 66 kilometers. Howland Island, measuring about 3.2 by 0.8 kilometers, is a low-lying (maximum 6 meters), nearly flat, sandy coral island surrounded by a narrow fringing reef. Baker Island, measuring about 1.6 by 1.4 kilometers, is also a low-lying (maximum 8 meters), nearly flat (somewhat depressed in the central area) coral island surrounded by a fringing reef. They are both reef islands consisting of low-lying accumulations of reef debris deposited on top of a reef platform without a lagoon. Both islands are described as equatorial, with scant rainfall, constant wind, and burning sun.

\section{Geologic Setting}

Howland and Baker Islands are composed of coral-reef platforms sitting atop Cretaceous ( $\sim 120-75$ million years old) volcanoes. The Howland-Baker EEZ contains about 10 other moderate-sized and many small Cretaceous seamounts that are either without coral reefs or capped by submerged reefs. At least one of the seamounts, Winslow Reef on the southeast boundary line of the EEZ, has a submerged coral-reef cap with the summit at about 1,500-meter water depth. Otherwise, the sea-floor topography of the EEZ is dominated by a sedimentcovered abyssal plain deeper than 5,000 meters.

\section{Offshore Mineral Deposits of Howland and Baker Islands}

The EEZ boundary to the south is shared with that of Kiribati's Phoenix Islands. Immediate- to long-term potential mineral resources occur within the EEZ of Howland and Baker Islands. Insular phosphorite was mined on both islands from 1850-1891 Mineral deposits likely to occur within the EEZ include:

\section{- Cobalt-rich iron-manganese crusts on Cretaceous} seamounts

- Iron-manganese nodules on the deep abyssal plain

- Phosphorite deposits on Cretaceous seamounts

- Insular phosphorite on Howland and Baker Islands

- Hydrothermal iron and manganese deposits on seamounts

- Shallow-water sand and gravel (aggregate) on and adjacent to Howland and Baker Islands

- Shallow- to deep-water precious coral on seamounts and islands slopes

Cobalt-rich iron-manganese crusts have been sampled from two seamounts within the Howland-Baker EEZ. Two dredge hauls taken in 1985 by German scientists recovered samples from Titov seamount, located southeast of Baker Island. The crust samples from those dredges have very high cobalt (mean 0.97 percent; maximum 1.3 percent) and nickel (mean 0.65 percent; maximum 0.88 percent) contents, among the highest in any Pacific EEZ. Crusts were collected from a seamount at the central-west margin of the EEZ, but the much 
older chemical data for that sample are of suspect quality and not considered here.

The distribution of crust deposits having high cobalt and nickel contents within the EEZ is not known. The seamounts in the EEZ are relatively small, or, for the plateau south of Baker Island, in too deep water to offer good prospects for a significant resource potential. Consequently, these deposits likely represent an intermediate- to long-term resource potential for cobalt, nickel, and possibly other metals, although the very high metal contents do warrant an additional sampling program.

Iron-manganese nodules likely occur on the sediment surface of the deep-water abyssal plain that characterizes most of the EEZ. The few age determinations of siliceous ooze from the abyssal plain suggest a slow rate of sediment accumulation, which would favor high nodule coverage and high nickel and copper contents. Very little work has been done on these deposits, however, and nodule distribution and grade have not been determined. Past work by Japanese scientists in nearby areas indicates that nodule coverage may be extensive and copper and nickel contents may be high to very high. If areas having nodules of favorable density and grades can be located within the Howland and Baker Islands EEZ, then these nodules would offer an intermediate-term resource potential because of the large area of sea floor represented by abyssal plain. It is recommended that an exploration program for nodules be carried out.

Phosphorite deposits on seamounts have been sampled from two dredges collected by German scientists in 1985. Phosphorite is abundant and of high grade in those dredges, indicating that it might be widespread within the EEZ on seamounts and on the plateau south of Baker Island. These deposits are typically either small, high-grade deposits or more widespread, low-grade deposits. This deposit type may have a long-term resource potential.

Insular phosphorite deposits occur on Howland and Baker Islands and were mined from 1850 to 1891. About 100,000 tonnes and 250,000 tonnes of insular phosphorite were mined from Howland Island and Baker Island, respectively. Reserves were exhausted, but further exploration for buried deposits and research to determine their origin are warranted. This work should include sampling of island outcrops and a drilling program on the carbonate platforms. Exploration and exploitation of additional deposits is unlikely, however, because of the islands' status as National Wildlife Refuges.

Hydrothermal iron and manganese deposits are likely to occur scattered throughout the region, but have not as yet been sampled. This deposit type may have a long-term resource potential.

Shallow-water and insular aggregate for construction consists of sand and gravel composed of coral and shell. Construction materials are ubiquitous on these islands, which are composed predominantly of unconsolidated carbonate $\left(\mathrm{CaCO}_{3}\right)$ sand and gravel. The east coast of Howland Island consists of coral rubble, whereas the west coast consists of beach sand. Exploration for nearshore and island sources of sand and gravel may identify deposits that can be extracted for local construc- tion without damage to the environment. In general, construction materials are common on this type of island, but it may be difficult to locate deposits where exploitation will not accelerate land loss, shoreline erosion, or result in permanent habitat loss. Nearshore deposits would be limited to the reef terrace (as much as 2 kilometers wide) surrounding the islands, which is submerged in 4 to 20 meters of water. Armor stone for use in revetments and shore protection can be mined from the reef flat of the narrow fringing reef (50 to 250 meters wide) and from beachrock deposits. Designation of these uninhabited islands as National Wildlife Refuges will limit development of aggregate resources.

Shallow- to deep-water precious coral may occur on seamounts and the island slopes within the Howland-Baker EEZ. Shallow-water black coral species typically occur in areas of steep rock faces swept by strong currents in water depths greater than 20 meters. Howland and Baker Islands should have numerous potential sites for precious coral. However, the distribution, abundance, and the resource potential of precious coral are unknown. A systematic exploration program is needed to delineate this resource. If important deposits are found, they would have an immediate economic market.

\section{Summary}

Aggregate, insular phosphorite, and precious coral could have an immediate economic impact if significant deposits and markets are found. Exploitation of these commodities would require maintenance of environmental and ecological quality and will be limited by the presence of wildlife refuges. Iron-manganese nodules offer an intermediate-term resource potential, whereas the other deposit types represent long-term or unknown resource potentials. Research cruises dedicated to understanding the distribution, grade, and tonnage of these potential resources are recommended.

\section{Selected References}

Halbach, P.E., Sattler, C.D., Teichmann, F., and Wahsner, M., 1989, Cobalt-rich and platinum-bearing manganese crust deposits on seamounts; nature, formation, and metal potential: Marine Mining, v. 8, p. 23-39.

Hein, J.R., Koschinsky, A., Bau, M., Manheim, F.T., Kang, J.-K., and Roberts, L., 2000, Cobalt-rich ferromanganese crusts in the Pacific in Cronan, D.S., ed., Handbook of marine mineral deposits: Boca Raton, Florida, CRC Press, p. 239-279.

Palfreyman, W.D., Doutch, H.F., Brathwaite, R.L., Masaharu, K., Piper, D.Z., Swint-Iki, T.R., McCoy, F.W., Sullivan, L.G., Manheim, F.T., and Lane-Bostwick, C.M., 1996, Mineral-resources map of circum-Pacific region, southwest quadrant: U.S. Geological Survey Circum-Pacific Map Series, 1 sheet, scale 1:10,000,000, with booklet, $66 \mathrm{p}$.

Piper, D.Z., McCoy, F.W., and Swint, T.R., 1985, Manganese nodules, sea floor sediment, and sedimentation rates for the circum-Pacific region: Tulsa, Oklahoma., American 
Association of Petroleum Geologists, 1 sheet, scale $1: 17,000,000$.

Piper, D.Z., Loebner, B., and Ahron, P., 1991, Physical and chemical properties of the phosphate deposit on Nauru, the equatorial Pacific, in Riggs, S., and Burnett, W., eds., Phosphate deposits of the world, v. III: London, Cambridge
University Press, p. 178-194.

Usui, A., ed., 1994, Marine geology, geophysics and manganese nodule deposits in the Penrhyn Basin, South Pacific, August-October 1983 (Hakurei-Maru Cruise GH833): Tsukuba, Japan, Geological Survey of Japan Cruise Report No. 23, 246 p. 

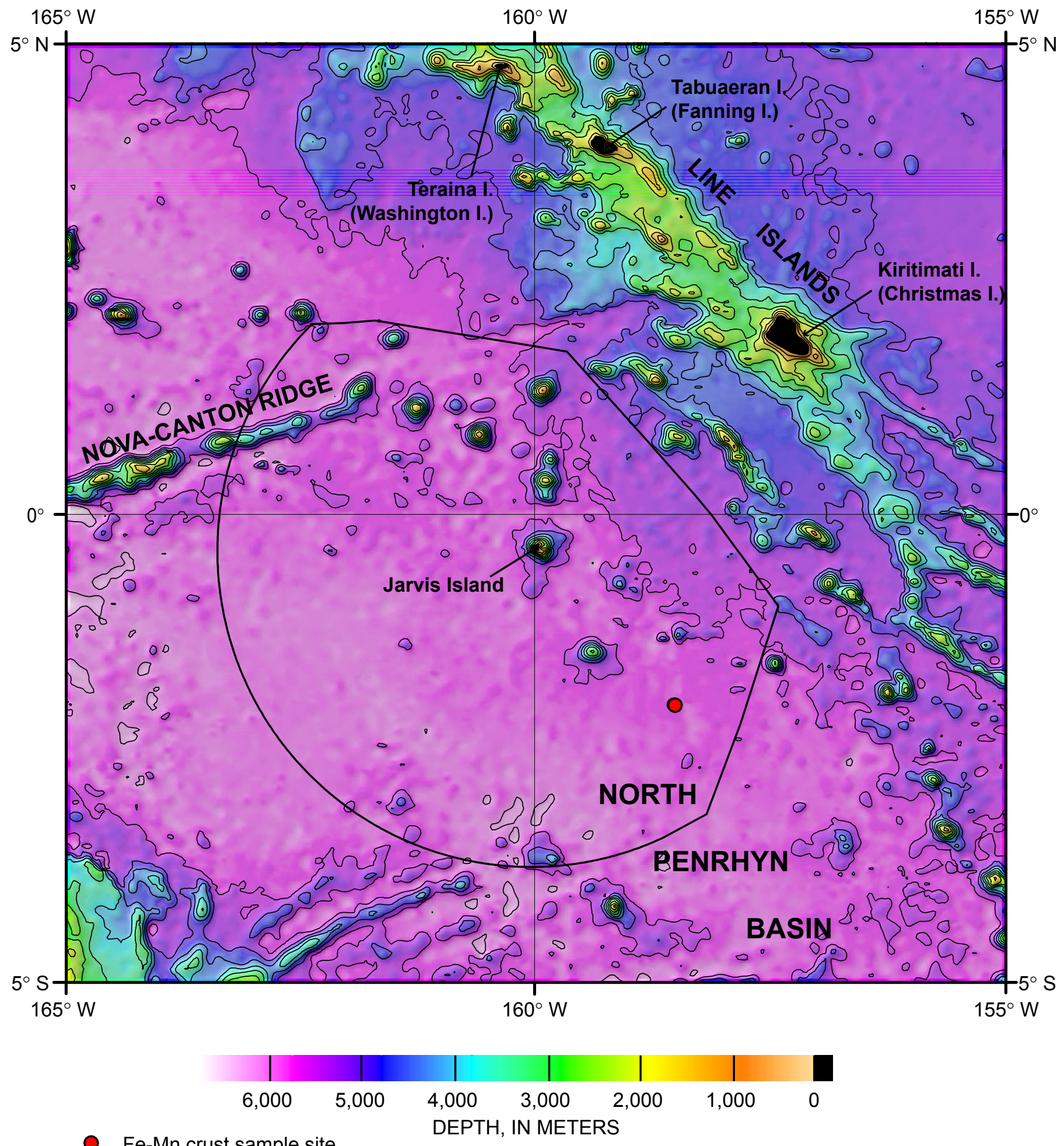

- Fe-Mn crust sample site

Figure 13. Bathymetric map of the Exclusive Economic Zone (EEZ) of Jarvis Island ("E" on fig.1); black line shows EEZ boundary. Contour interval is 500 meters. The Kiribati EEZ borders the Jarvis Island EEZ to the north, east, and southeast. 


\section{Jarvis Island}

Land Area:
EEZ Area:

Political Status:

Population: Island Minerals:
$4.5 \mathrm{~km}^{2}$

$323,100 \mathrm{~km}^{2}$ (see fig. 13); location shown by "E" on figure 1

Unincorporated territory of the United States

Uninhabited

Phosphorite/guano

\section{Island History}

Jarvis Island was discovered in 1821 by Captain Brown on the British ship Eliza Francis. Alfred G. Benson and Charles H. Judd took formal possession of the island in 1857 in the name of the American Guano Company of New York. Later that year, Commander Charles Henry Davis of the USS St. Mary surveyed the island and formally claimed it for the United States. Jarvis Island was mined for guano in the late 1800s. Under the Guano Act of 1856 (see the section on Howland-Baker Islands for a description of the Guano Act), it became a U.S. possession. Jarvis was abandoned in 1879 after many tonnes of guano had been removed. The United Kingdom annexed the island in 1889 , but did not further develop the mining operations. In 1906 it was leased to the Pacific Phosphate Company of London, but again mining was not further developed. The United States reoccupied and reclaimed Jarvis in 1935 and it was placed under the jurisdiction of the Department of the Interior on May 13, 1936 (Executive Order 7368). The new colonists were evacuated from the island in 1942 following attacks by Japanese forces, and the island has remained mostly uninhabited since then. In 1957-1958, Millersville, on the western side of the island, was occupied by scientists during the International Geophysical Year. Since June 1974, the island has been administered by the U.S. Department of the Interior Fish and Wildlife Service as part of the National Wildlife Refuge system.

\section{Geography}

Jarvis Island is located just south of the equator about 1,850 kilometers east of Howland and Baker Islands. The island is about 3.2 kilometers long and 1.6 kilometers wide. Jarvis consists of a relatively flat (mostly 4.6 to 6.1 meters high; maximum 7 meters), sandy, coral island platform with a lower central basin and a narrow fringing reef. A submarine terrace (water depth 4 to 20 meters) extends to one kilometer offshore. The island is described as tropical with little rainfall, constant wind, and burning sun.

\section{Geologic Setting}

Jarvis Island is part of the Line Islands linear volcanic chain, most of which is part of Kiribati. This linear array of islands and seamounts has been considered a hot-spot trace similar to that of Hawai'i, but recent work has shown that the age of volcanoes is nearly the same along major segments of the chain. This suggests nearly coeval volcanism along a preexisting zone of weakness. A few small to moderate-size seamounts occur within the Jarvis Island EEZ, with ages of about 70 to 40 million years. The dominant sea-floor topography is an abyssal plain more than 5,000 meters deep. Sediment in the south and west parts of the EEZ is siliceous ooze, whereas in the north and east it is carbonate ooze.

\section{Offshore Mineral Deposits of Jarvis Island}

The EEZ boundary to the north and east is shared with Kiribati's Line Islands. Immediate- to long-term potential mineral resources may occur within the EEZ of Jarvis Island. There have been no marine mineral surveys within the Jarvis Island EEZ and only one mineral deposit sample has been collected there. The sea-floor bathymetry and resource potential are likely to be comparable to those of the Howland-Baker Islands EEZ. Mineral deposits likely to occur within the EEZ include:

- Cobalt-rich iron-manganese crusts on sea mounts

- Iron-manganese nodules on the deep abyssal plain

- Phosphorite deposits on seamounts

- Insular phosphorite on Jarvis Island

- Hydrothermal iron and manganese deposits on seamounts

- Shallow-water sand and gravel (aggregate) on and adjacent to Jarvis Island

- Shallow- to deep-water precious coral on seamounts and island flanks

Cobalt-rich iron-manganese crusts have not been studied within the Jarvis Island EEZ. One sample collected and analyzed in the 1960s is described as a manganese-coated rock and may be a nodule rather than a crust, as indicated by its chemistry and deep-water collection site (5,080 meters). This sample has relatively high nickel ( 0.77 percent $)$ and copper ( 0.54 percent) contents, and low cobalt $(0.15$ percent $)$. If this is a nodule, the nickel-plus-copper content of 1.31 percent is above the cutoff grade of 1.18 percent (see discussion in appendix 2). Work in the Line Islands to the east of Jarvis by British scientists indicates that crusts rich in cobalt and nickel should occur on seamounts in the Jarvis Island EEZ. However, the seamounts in the EEZ are relatively few, small, and too deep to offer a promising resource potential for the foreseeable future. These deposits likely represent a long-term resource potential for cobalt, nickel, and other metals. 
Iron-manganese nodules likely occur on the sediment surface of the deep-water abyssal plain that characterizes most of the EEZ, but no surveys have been done and only one possible sample has been analyzed (see discussion for cobalt-rich crusts above). If the nickel-plus-copper content (1.31 percent) of that nodule is representative of nodules in the EEZ, then they would be considered as a potential resource. Work by Japanese and British scientists in nearby areas indicates that nodule coverage may be extensive and copper and nickel contents may be high to very high. These findings are in agreement with the occurrence of siliceous ooze to the south and west of the island and the low sediment accumulation rate. If areas of favorable nodule density and grades can be located within the Jarvis Island EEZ, then these nodules would offer an intermediate-term potential because of the large area of sea floor represented by abyssal plain. It is strongly recommended that an exploration program for nodules be carried out.

Phosphorite deposits on seamounts within the Jarvis Island EEZ have not been sampled. However, samples collected from seamounts in adjacent areas indicate that phosphorite might be widespread within the EEZ. These deposits are typically either small, high-grade deposits or more widespread, lowgrade deposits that may have a long-term resource potential.

Insular phosphorite deposits of high grade are known to occur on Jarvis Island. In the late 1800s, about 200,000 tonnes of phosphorite was mined on the island; the amount remaining is unknown. An exploration program for insular phosphorite should include sampling of island outcrops and a drilling program on the carbonate platform. Discovery of rich phosphorite deposits could have an immediate economic impact. If viable deposits are found, however, mining would take place only as the result of extreme need because the island is a National Wildlife Refuge.

Hydrothermal iron and manganese deposits are likely to occur scattered throughout the region, but have not as yet been sampled. This deposit type may have a long-term resource potential.

Shallow-water and insular aggregate for construction consists of sand and gravel composed of coral and shell. Construction materials are ubiquitous on reef islands, because they are predominantly composed of unconsolidated sand and gravel. Armor stone for use in revetments and shore protection can be mined from the reef flat of the narrow fringing reef and from beachrock deposits. Exploration for nearshore and island sand and gravel should identify deposits that can be used for local construction. Nearshore deposits would be limited to the submerged reef terrace surrounding the island. In general, construction materials are common on this type of island, but it is important to identify deposits where exploitation will not accelerate land loss or shoreline erosion, nor result in permanent habitat loss. The designation of this uninhabited island as a National Wildlife Refuge will limit the extraction of aggregate.

Shallow- to deep-water precious coral may occur on seamounts and the island flanks within the Jarvis EEZ.
Because its distribution and abundance are unknown, a systematic exploration program is required to evaluate its resource potential. If deposits are found, they could have an immediate economic market.

\section{Summary}

Aggregate, precious coral, and especially insular phosphorite could have an immediate economic impact if significant deposits and markets are found. Exploitation of these commodities would require addressing environmental and ecological issues. Nickel- and copper-rich nodules may offer an intermediate-term resource potential. The other deposit types represent long-term or unknown resource potential. Exploration directed to understanding the distribution, grade, and tonnage of these potential resources is recommended. The designation of Jarvis Island as a National Wildlife Refuge will limit activity in the vicinity of the island.

\section{Selected References}

Aplin, A.C., and Cronan, D.S., 1985, Ferromanganese oxide deposits from the central Pacific Ocean, I. Encrustations from the Line Islands Archipelago: Geochimica et Cosmochimica Acta, v. 49, p. 427-436.

Corvalan, D.J., Guild, P.W., Piper, D.Z., Swint-Iki, T.R., McCoy, F.W., Sullivan, L.G., Manheim, F.T., Lane-

Bostwick, C.M., and Luepke, G., 1996, Mineral-resources map of the circum-Pacific region, southeast quadrant: U.S. Geological Survey circum-Pacific Map Series CP-42, scale 1:10,000,000, with booklet, $30 \mathrm{p}$.

Davis, A.S., Gray, L.B., Clague, D.A., and Hein, J.R., 2002, The Line Islands revisited; new ${ }^{40} \mathrm{Ar}{ }^{39} \mathrm{Ar}$ geochronologic evidence for episodes of volcanism due to lithospheric extension: Geochemistry, Geophysics, Geosystems, v. 3, no. 3, 10.1029/2001GC000190, 28 p.

Hein, J.R., Koschinsky, A., Bau, M., Manheim, F.T., Kang, J.-K., and Roberts, L., 2000, Cobalt-rich ferromanganese crusts in the Pacific, in Cronan, D.S., ed., Handbook of marine mineral deposits: Boca Raton, Florida, CRC Press, p. 239-279.

Palfreyman, W.D., Doutch, H.F., Brathwaite, R.L., Masaharu, K., Piper, D.Z., Swint-Iki, T.R., McCoy, F.W., Sullivan, L.G., Manheim, F.T., and Lane-Bostwick, C.M., 1996, Mineral-resources map of circum-Pacific region, southwest quadrant: U.S. Geological Survey CircumPacific Map Series, 1 sheet, scale 1:10,000,000, with booklet, $66 \mathrm{p}$.

Usui, A., ed., 1994, Marine geology, geophysics and manganese nodule deposits in the Penrhyn Basin, South Pacific, August-October 1983 (Hakurei-Maru Cruise GH833): Tsukuba, Japan, Geological Survey of Japan Cruise Report No. 23, 246 p. 
(Section on Johnston Atoll begins on following pages.) 

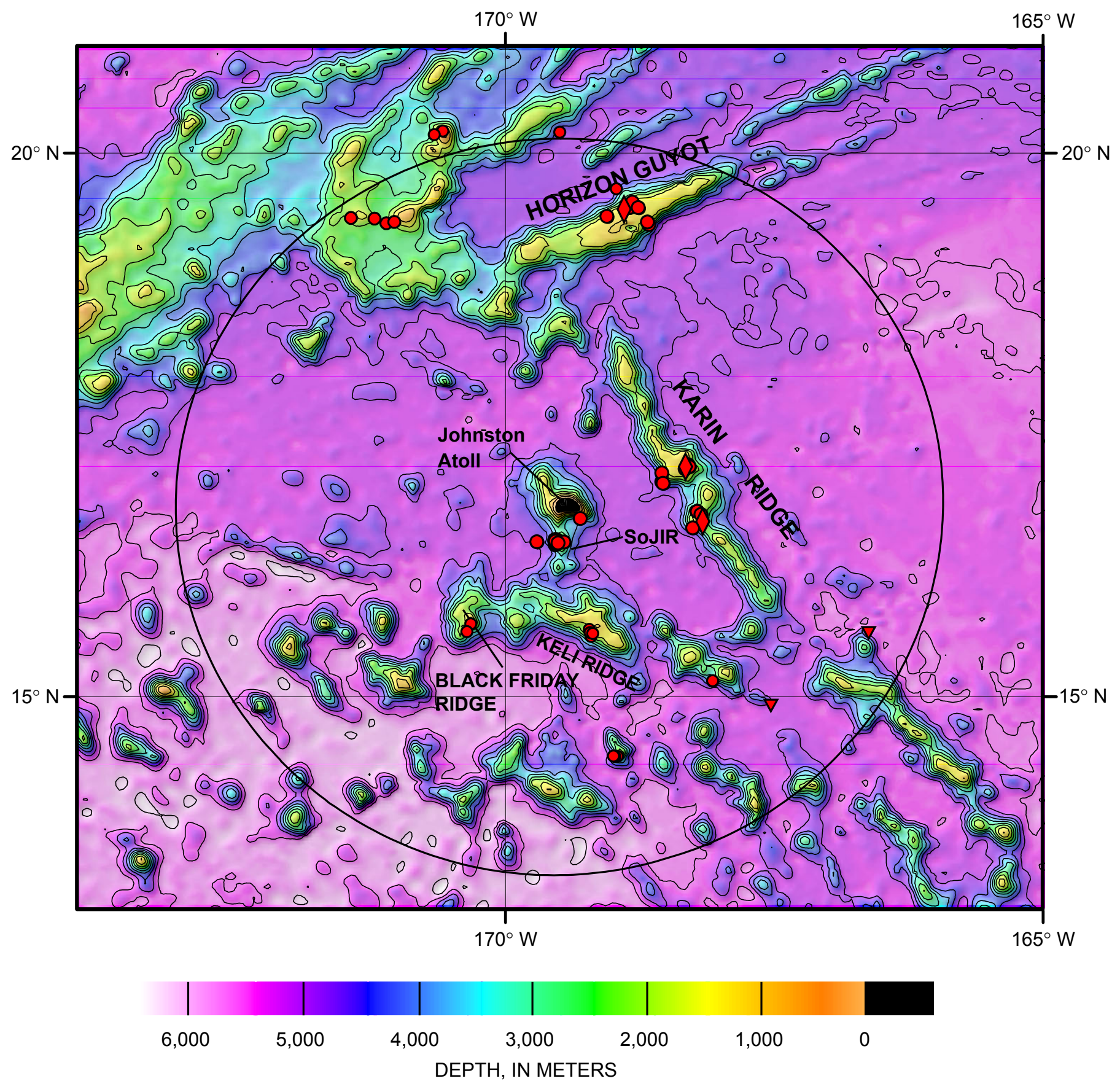

- Fe-Mn crust sample sites

$\checkmark$ Hydrothermal ironstone sample sites

$\nabla$ Fe-Mn nodule sample sites

Figure 14. Bathymetric map of the Exclusive Economic Zone (EEZ) of Johnston Atoll (" $F$ ” on fig.1); black line shows EEZ boundary. Contour interval is 500 meters. SoJIR is South Johnston Island Ridge. 


\section{Johnston Atoll}

\section{Land area: \\ EEZ area:}

Political status:

Population:

Island minerals:

\section{Island History}

Johnston Atoll was sighted in 1796 by the U.S. Brig Sally under the command of Joseph Pierpoint, but it was named for Captain James Johnston of the HBMS Cornwallis, who claimed its official discovery on December 14, 1807. In March 1858, the captain of the U.S. schooner Palestine claimed the island for the United States, and three months later the island was claimed by Captain Watson of the Hawaiian schooner Kalama for the Kingdom of Hawai'i. Two crew members from the schooner Palestine were left on the island to collect phosphate. The island was annexed to the United States as a guano island under the Guano Act of 1856 (see description under Howland-Baker Islands). A large amount of guano was removed from the atoll between the late 1850s and the early 1900s. The atoll did not have a permanent population until 1936.

On July 29, 1926, President Calvin Coolidge established Johnston Atoll as a Federal bird refuge by Executive Order 4467 and placed it under the control of the U.S. Department of Agriculture. On December 29, 1934, Executive Order 6935 by President Franklin Roosevelt transferred control of Johnston Atoll jointly to the U.S. Navy to establish an air station and also to the Department of the Interior to administer the bird refuge. In 1936, the U.S. Navy began developing a seaplane base, an airstrip, and refueling facilities. These facilities served as an important link between Hawai' $i$ and the western Pacific during World War II. The atoll was fortified during the war and used as a supply point for submarines.

The Secretary of the Navy agreed to transfer operational control of Johnston Atoll to the U.S. Air Force on July 1, 1948, to be used for nuclear testing. Johnston Atoll was used as the launch site for atmospheric nuclear weapons tests in the 1950s and 1960s. In the 1960s, three missiles carrying nuclear warheads were destroyed by nonnuclear explosions, one on the launch pad and two at altitudes of 9 and 33 kilometers, which spread plutonium- and uranium-containing particles over the atoll. The Department of the Air Force signed an agreement with the Defense Nuclear Agency on July 1, 1973, to administer and host-manage the island. In the 1990s, the atoll was used as a site for a Chemical Agent Disposal System (JACADS) that incinerated chemical weapons. The Atoll is now administered by the U.S. Defense Threat Reduction Agency and managed cooperatively with the U.S. Fish and Wildlife Service as part of the National Wildlife Refuge system.

\section{Geography}

Johnston Atoll is located about 1,330 kilometers westsouthwest of Honolulu. The atoll is highly modified and consists of one large island (Johnston Island) and several small islets (Akau, Sand, Hikina) in a lagoon flanked by a barrier reef only on the northwest margin of the atoll.Johnston and Sand Islands are natural islands that have been significantly expanded by coral dredging, whereas Akau and Hikina Islands are entirely manmade from coral dredged from the reef. Johnston Island, a flat sand-and-coral island with a highest elevation of about 4 to 5 meters, is flat because it was leveled for construction purposes, such as the building of a runway.

\section{Geologic Setting}

Johnston Atoll is the northernmost island in the Line Islands chain. All but the northwest part of the atoll barrier reef has subsided, and reef growth has been unable to keep pace with the rate of subsidence; it may be in transition from an atoll to a seamount. The volcanic pedestal below Johnston Atoll is about 71 million years old. The Johnston Atoll EEZ consists of a complex array of Cretaceous (86 to 69 million years old) volcanic ridges and seamounts. Karin Ridge is 86 to 81 million years old and is the largest volcanic edifice in the EEZ. It trends northwest-southeast and is continuous with the Line Islands ridge to the southeast of the EEZ. Karin Ridge has been sampled for cobalt-rich iron-manganese crusts during two USGS cruises. Horizon Guyot, an elongate flat-topped seamount, trends northeast-southwest, nearly at right angles to Karin Ridge, and is 82 million years old. Horizon Guyot has also been sampled for crusts on USGS and other cruises. Keli Ridge is 72 to 69 million years old and trends more east-west than Karin Ridge. Keli Ridge has been sampled for crusts during two German cruises. The flat summit of Horizon Guyot is sediment covered, whereas the summits of Karin and Keli Ridges are mostly free of sediment.

Many other large and small seamounts occur within the EEZ (see fig. 14), but they have not been sampled. Although the Johnston Atoll EEZ has been relatively well studied for iron-manganese crusts, the majority of the seamounts in the EEZ have not been sampled. About 40 percent of the EEZ is dominated by sediment-covered abyssal plains deeper than 5,000 meters. 


\section{Offshore Mineral Deposits of Johnston Atoll}

Cobalt-rich iron-manganese crusts and seamount phosphorites have been systematically sampled and studied at many sites within the Johnston Atoll EEZ by U.S. research cruises and by joint U.S.-German, U.S.-Japanese, and U.S.Russian cruises. However, other mineral-deposit types have not been systematically surveyed in the EEZ, which likely contains immediate- to long-term potential mineral resources. Guano phosphorite was mined on the island from 1850 to 1900. Mineral deposits that do or are likely to occur within the EEZ include:

- Cobalt-rich iron-manganese crusts on seamounts and ridges

- Iron-manganese nodules on the deep abyssal plains

- Phosphorite deposits on seamounts and ridges

- Insular and lagoonal phosphorite on Johnston Atoll

- Hydrothermal iron and manganese deposits on sea mounts and ridges

- Shallow-water sand and gravel (aggregate) on Johnston Atoll

- Shallow- to deep-water precious coral on seamounts, ridges, and the island slopes

Cobalt-rich iron-manganese crusts have been relatively extensively studied within the Johnston Atoll EEZ. This EEZ contains widespread crust deposits with high contents of cobalt and nickel and moderate contents of platinum. Both crust thicknesses and grades exceed cut-off levels for potential mining (see appendix 2). The U.S. Minerals Management Service completed an environmental impact statement for crust mining in the EEZ of Johnston Atoll and Hawaii. In 1981 and again in 1984, the German ship R.V. Sonne sampled crusts and phosphorite in the Johnston Atoll EEZ, on Keli Ridge, Black Friday Ridge, and several unnamed seamounts. In 1984, the U.S. ship S.P. Lee sampled Horizon Guyot and the Johnston Island volcanic edifice for crusts and phosphorite. In 1986, U.S. and Japanese scientists on the British ship Farnella sampled Karin Ridge and South Johnston Island Ridge for crusts and phosphorite. In 1991, a joint United States-Russian cruise aboard the Russian ship R.V. Vinogradov also sampled Karin Ridge for crusts and phosphorite.

A compilation of chemical data for 103 crust samples collected within the EEZ gives mean cobalt, nickel, and copper contents of $0.74,0.12$, and 0.44 percent, respectively. The mean cobalt content is among the highest for crusts within Pacific EEZs. Crusts in this EEZ have the highest mean titanium and zirconium contents and relatively high cerium and tellurium concentrations compared to crust means for other EEZs in the Pacific. Johnston Atoll EEZ has one of the best potentials for this deposit type among Pacific island EEZs. These deposits likely represent an near- to intermediate-term resource potential for cobalt, nickel, and possibly other metals. Additional exploration work is strongly warranted to further delineate the distribution and thickness of high-grade crusts.
Iron-manganese nodules occur on the sediment surface of the deep-water abyssal plains to the east of Karin Ridge and to the west of Johnston Atoll. Very little work has been done on these deposits, and nodule distribution and grade are very poorly known. However, GLORIA side-scan sonar images (see appendix 2) taken of the sea floor in 1990 indicate that nodule coverage may be extensive, in agreement with abundances seen on the few available bottom photographs. Nodules farther to the east on the sea floor below international waters (Clarion-Clipperton Zone) have been well studied. They are abundant and contain high concentrations of copper and nickel. In the Central Pacific basin to the southwest, nodules are extremely abundant and have intermediate concentrations of nickel, copper, and cobalt. If areas of favorable nodule density and favorable grades can be located within the Johnston Atoll EEZ, they would offer an intermediate-term resource potential.

Phosphorite deposits are widespread on seamounts and ridges within the EEZ and occur in the same places as the iron-manganese crusts. Phosphorites were sampled during many cruises in the Johnston Atoll EEZ (see section on cobaltrich crusts). These deposits are high grade and cover extensive areas. Additional exploration is warranted, even though this deposit type is likely to have only a long-term resource potential.

Insular phosphorite deposits mined on Johnston Atoll in the late 1850 s to 1890 s and early 1900 s were of rather poor quality compared to those on Jarvis, Howland, and Baker Islands. Extensive modifications made to the islands in support of the U.S. military have further contributed to removal of this deposit as a viable resource. The potential for lagoonal phosphorites is unknown, because the cores from drilling in the lagoon have not been available for scientific study. The lagoonal phosphorite resource potential is probably small; exploitable insular phosphorite deposits occur within enclosed lagoons, whereas Johnston Atoll is an open system. Further mining operations in the vicinity of the atoll would conflict with military operations and its status as a fish and wildlife refuge.

Hydrothermal iron and manganese deposits are likely to occur scattered throughout the region, and have been sampled at five location (see fig. 14). This deposit type may have a long-term resource potential.

Shallow-water aggregate that can be used for construction consists of sand and gravel composed of coral and shell. Extensive construction has occurred on the islands of Johnston Atoll using hard-packed coral gravel and cement. Exploration for lagoonal and nearshore sand and gravel may identify deposits of this commodity that have immediate economic importance for local construction. Defense agencies likely possess information on the sand and gravel potential, but those documents are not presently available to us.

Shallow- to deep-water precious coral likely occurs on seamounts and ridges in the Johnston Atoll EEZ. Bamboo coral was collected in many dredges that sampled crusts and phosphorite. However, the distribution, abundance, and 
resource potential of precious coral are unknown. Shallowwater black coral species typically occur in areas of steep rock faces swept by strong currents in water depths greater than 20 meters. Johnston Atoll appears to have numerous potential sites for precious coral. A systematic exploration program is needed to delineate this potential resource. If important deposits are found, they would have an immediate economic market.

\section{Summary}

Aggregate and precious coral could have an immediate economic impact if significant deposits and markets are found. Significant cobalt-rich crust deposits occur throughout the EEZ, and those deposits may offer a near- to intermediateterm resource potential. Iron-manganese nodules may offer an intermediate-term resource potential. The other deposit types represent long-term or unknown resource potential. Reconnaissance cruises dedicated to understanding the distribution, grade, and tonnage of nodules and additional cruises to define the crust resource are recommended.

\section{Selected References}

Davis, A.S., Gray, L.B., Clague, D.A., and Hein, J.R., 2002, The Line Islands revisited; new ${ }^{40} \mathrm{Ar} /{ }^{39} \mathrm{Ar}$ geochronologic evidence for episodes of volcanism due to lithospheric extension: Geochemistry, Geophysics, Geosystems, v. 3, no. 3, 10.1029/2001GC000190, 28 p.

Guild, K.M., Lee, M.P., Corvalan, D.J., Dawson, K.M., Paidakovich, M.E., Salas, S.J., Piper, D.Z., Swint, T.R., Sullivan, L.G., McKelvey, V.E., Mizuno, A., Younse, G.A., 1984, Mineral-resource map of the circum-Pacific region, northeast quadrant: Tulsa, Oklahoma, America Association of Petroleum Geologists, Circum-Pacific Map Project, 1 sheet, 1:10,000,000 scale.

Halbach, P., Manheim, F.T., and Otten, P., 1982, Co-rich ferromanganese deposits in the marginal seamount regions of the Central Pacific Basin-results of the Midpac '81:
Erzmetall, v. 35, p. 447-453.

Halbach, P.E., Sattler, C.D., Teichmann, F., and Wahsner, M., 1989, Cobalt-rich and platinum-bearing manganese crust deposits on seamounts; nature, formation, and metal potential: Marine Mining, v. 8, p. 23-39.

Hein, J.R., 2002, Cobalt-rich ferromanganese crusts; global distribution, composition, origin, and research activities, in Polymetallic massive sulphides and cobalt-rich ferromanganese crusts; status and prospects: Kingston, Jamaica, International Seabed Authority Technical Study No. 2, p. 36-89.

Hein, J.R., Manheim, F.T., Schwab, W.C., and Davis, A.S., 1985, Ferromanganese crusts from Necker Ridge, Horizon Guyot, and S.P. Lee Guyot; geological considerations: Marine Geology, v. 69, p. 25-54.

Hein, J.R., Manheim, F.T., Schwab, W.C., Davis, A.S., Daniel, C.L., Bouse, R.M., Morgenson, L.A., Sliney, R.E., Clague, D., Tate, G.B., and Cacchione, D.A., 1985, Geologic and geochemical data for seamounts and associated ferromanganese crusts in and near the Hawaiian, Johnston Island, and Palmyra Island Exclusive Economic Zones: U.S. Geological Survey Open-File Report 85-292, 129 p.

Hein, J.R., Bychkov, A.S., and Gibbs, A.E., eds., 1994, Data and results from R.V. Aleksandr Vinogradov cruises 91AV-19/1, north Pacific hydrochemistry transect; 91-AV19/2, north equatorial Pacific Karin Ridge Fe-Mn crust studies; and 91-AV-19/4, northwest Pacific and Bering Sea sediment geochemistry and paleoceanographic studies: U.S. Geological Survey Open-File Report 94-230, 292 p.

Hein, J.R., Koschinsky, A., Bau, M., Manheim, F.T., Kang, J.-K., and Roberts, L., 2000, Cobalt-rich ferromanganese crusts in the Pacific, in Cronan, D.S., ed., Handbook of marine mineral deposits: Boca Raton, Florida, CRC Press, p. 239-279.

Piper, D.Z., McCoy, F.W., and Swint, T.R., 1985, Manganese nodules, sea floor sediment, and sedimentation rates for the circum-Pacific region: Tulsa, Oklahoma, America Association of Petroleum Geologists, 1 sheet, scale $1: 17,000,000$ 


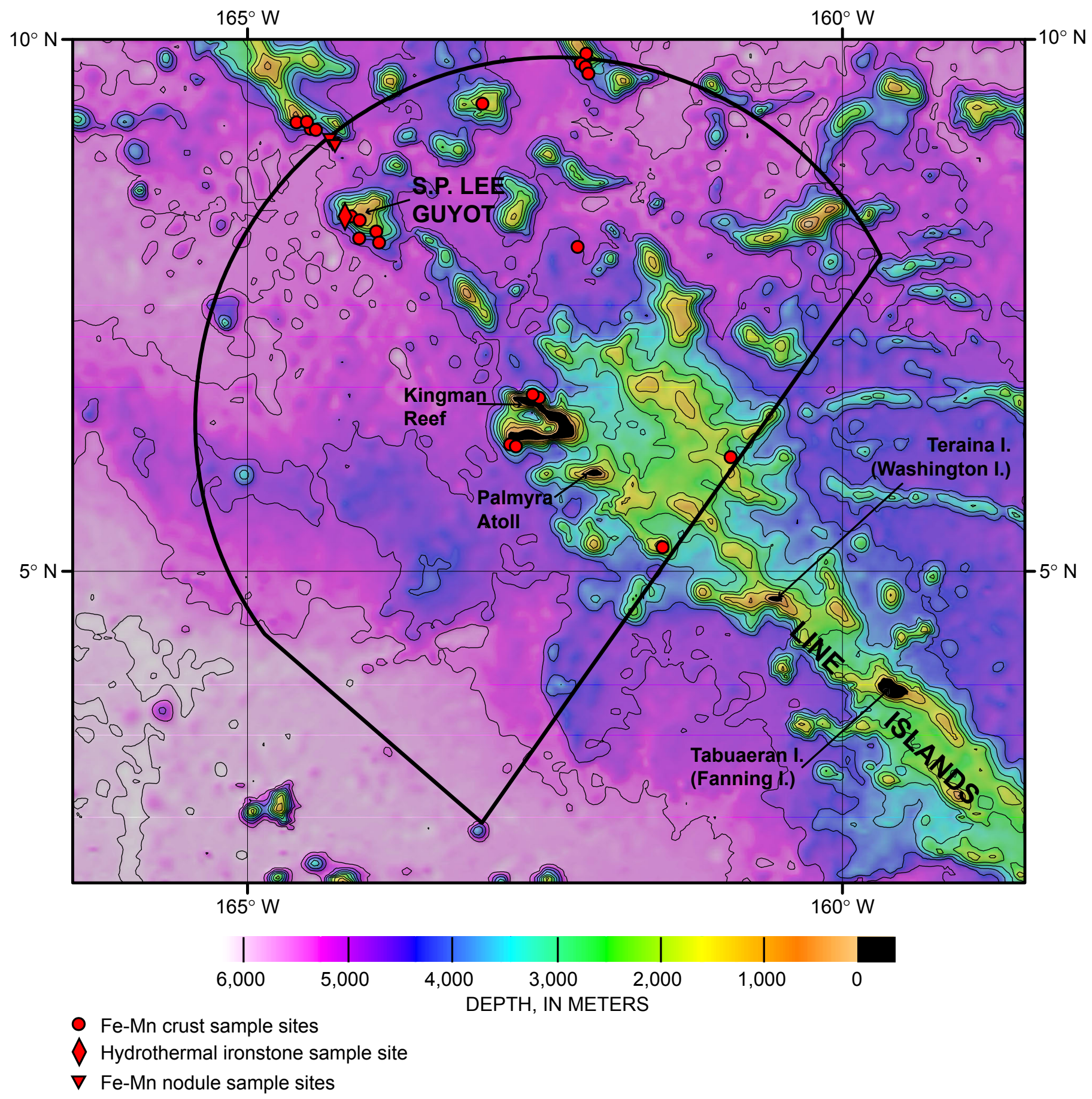

Figure 15. Bathymetric map of the Exclusive Economic Zone (EEZ) of Kingman Reef and Palmyra Atoll (“G” on fig.1); black line shows EEZ boundary. Contour interval is $\mathbf{5 0 0}$ meters. The Kiribati EEZ borders the Kingman Reef and Palmyra Atoll EEZ to the southeast. 


\section{Kingman Reef and Palmyra Atoll}

Land area:

EEZ area:

Political status:

Population: Island minerals:
$1 \mathrm{~km}^{2}$ (Kingman), $11.9 \mathrm{~km}^{2}$

(Palmyra)

411,600 $\mathrm{km}^{2}$ (see fig. 15); location shown by " $G$ " on figure 1

Unincorporated territory of the United States (Kingman); incorporated territory of the United States, Privately Owned (Palmyra)

Uninhabited

Aggregate

\section{Island History}

Kingman Reef and Palmyra Atoll are located about 1,713 and 1,778 kilometers south of Honolulu, respectively. They are separated by about 61 kilometers.

Kingman Reef was named for Captain W. E. Kingman, who discovered it on November 29, 1853, while aboard the U.S. ship Shooting Star. He said that it was near the place called Danger Rock on some charts and, under that name, it was one of the islands claimed by the United States under the Guano Act of 1856. However, the reef was first sighted by Edmund Fanning in 1798 aboard the U.S. ship Betsy.

The American flag was planted on Kingman Reef on May 10, 1922 by Lorrin A. Thurston, who engineered the annexation of Hawai'i by the United States, at the request of Leslie and Ellen Fullard-Leo, then owners of nearby Palmyra Atoll. He took formal possession by reading a proclamation of annexation, and leaving a record of the proceedings, a certificate of possession, the flag, and copies of the Honolulu Advertiser and Star-Bulletin dated May 3, 1922 , all placed at the base of a cairn of coral slabs about 1.2 meters high. On December 29, 1934, by Executive Order of President Franklin D. Roosevelt, Kingman Reef was placed under the control and jurisdiction of the U.S. Navy, administered from the 14th Naval District. On February 14, 1941, President Roosevelt issued a second Executive Order making Kingman Reef a U.S. national defense area and prohibiting foreign planes and surface craft.

Palmyra Atoll was named on November 7, 1802, for the U.S. ship Palmyra commanded by Captain Sawle, but was probably first sighted four years earlier by Captain Edmund Fanning aboard the American ship Betsy. On the orders of King Kamehameha IV, Hawai'i annexed Palmyra in 1862. The United States later annexed it along with the Hawaiian Islands by the joint resolution of Congress of 1898. Later, Congress excluded Palmyra from the Hawaiian boundaries in the Hawai'i Statehood Act.
The atoll changed private ownership four times between 1888 and 1911. In 1911, Judge Henry E. Cooper of Honolulu acquired title to the island and used it for growing coconuts. He sold all but two islets to Leslie and Ellen Fullard-Leo in August 1922. When the judge died in 1929, his two islets (Home Islands) were passed to his heirs. Until 2000, ownership of the rest of Palmyra was shared by Fullard-Leo's three sons, Leslie, Dudley, and Ainsley, who live in Hawaii.

During World War II, the U.S. Navy had 600 personnel on the island. The navy dredged a seaplane runway that merged the two western lagoons into one, built a causeway on the remaining reef, and joined three of the former islets into one. They also built an 1,800-meter runway that was used by the U.S. Air Force until 1961 but is now unserviceable. It took the Fullard-Leo family many court battles to reclaim Palmyra from the military after the war, which were finally settled by a Supreme Court decision in 1947. In December 2000, the Nature Conservancy purchased Palmyra Atoll for about $\$ 30$ million from the three Fullard-Leo brothers. The following January, the U.S. Fish and Wildlife Service approved a National Wildlife Refuge for Palmyra, and for Kingman Reef as well.

\section{Geography}

Kingman Reef is a low and nearly flat, V-shaped reef with a maximum elevation of about 1 meter and a central lagoon. It is wet or awash most of the time, so is not usable for occupation. At times, the east end is exposed at low tide and supports sand cay islands. The V-shaped bit of reef remaining is part of a larger atoll that is now mostly submerged. Kingman Reef has an equatorial climate that is hot and rainy.

Palmyra Atoll is composed of about 50 islets forming a U-shape, surrounded by a barrier reef. There is a lagoon to the east of the islets as well as within the central part of the U-shape, which is open to the west. The islets are nearly flat with a maximum elevation of 2 meters, although trees up to about 25 meters tall make them look significantly higher. Palmyra Atoll has an equatorial climate that is hot and rainy.

\section{Geologic Setting}

The Cretaceous volcanoes that underlie Kingman Reef and Palmyra Atoll are part of the Line Islands volcanic chain. Three samples from seamounts in or near the EEZ give ages of 84,70 , and 69 million years. All of the seamounts within the EEZ probably have ages within that range of 84 to 69 million years. The Kingman-Palmyra EEZ contains about seven large seamount complexes and ridges, as well as smaller edifices (fig. 15). The remainder of the EEZ consists of sedimentcovered abyssal plain at water depths of about 4,000 to 4,800 meters. The very large S.P. Lee Guyot ( 80 by 125 kilometers) was sampled on a USGS cruise and found to be about 80 per- 
cent sediment covered on its summit and upper flanks, with the remainder coated with rather thin cobalt-rich iron-manganese crusts. Several other seamounts in the EEZ and just outside the northern EEZ boundary have also been sampled and analyzed.

\section{Offshore Mineral Deposits of Kingman-Palmyra Islands}

The Kingman-Palmyra EEZ forms a half circle because the southeast boundary also forms the northwest EEZ boundary of Kiribati's Line Islands. Within the Kingman-Palmyra EEZ likely occur immediate- to long-term potential mineral resources. Mineral deposits within the EEZ are similar to those that occur within the Johnston Atoll EEZ, but with greater amounts of phosphorite. The following mineral-deposit types likely occur in the EEZ:

- Cobalt-rich iron-manganese crusts on seamounts and ridges

- Iron-manganese nodules on the deep abyssal plains

- Phosphorite deposits on seamounts and ridges

- Insular and lagoonal phosphorite

- Hydrothermal iron and manganese deposits on sea mounts and ridges

- Shallow-water and insular sand and gravel (aggregate)

- Shallow- to deep-water precious coral on seamounts, islands, and ridges

Cobalt-rich iron-manganese crusts from S.P. Lee Guyot, from several smaller unnamed seamounts, and from the flanks of Kingman Reef and Palmyra Atoll, all within the Kingman-Palmyra EEZ (fig. 15), were collected and studied by USGS and German scientists. In addition, crusts were collected from a seamount that lies just outside the northern EEZ boundary. Thirty-four samples have been chemically analyzed. These crusts have some of the highest cobalt concentrations (average 1.2 percent; maximum 2.5 percent) measured in samples from the Pacific, as well as high nickel (average 0.70 percent), titanium, and cerium contents and moderate copper ( 0.10 percent) and platinum contents. However, the crusts are generally thin because of abundant sediment cover in this equatorial zone of high bioproductivity. It is likely that thicker metal-rich crusts will be found on some of the seamounts within this EEZ that have not yet been sampled; for example, in areas where bottom currents have prohibited the accumulation of sediment. These deposits represent an intermediate-term resource potential for cobalt, nickel, and possibly platinum and other metals. The Kingman-Palmyra EEZ has a significant potential to contain crust deposits of high grade and tonnage. It is recommended that additional exploration be undertaken.

Iron-manganese nodules occur on the sediment surface of the deep-water abyssal plain to the west of the islands. Little work has been done on these deposits, and nodule distribution and grade are poorly known. However, GLORIA side-scan sonar images taken in 1990 of the sea floor indicate that nodule coverage may be extensive. Slow sedimentation rates in the abyssal areas support the likelihood of extensive nodule coverage, comparable to the extremely high nodule coverage immediately to the north in the Central Pacific Basin. The dominant sediment is thought to be siliceous ooze, similar to that in the nodule province farther to the east in international waters (Clarion-Clipperton Zone). There, extensive investigations by industry, governments, and academia have established that the nodules are abundant and contain high contents of copper and nickel. If areas of favorable nodule density and grades can be located within the Kingman-Palmyra EEZ, then these nodules would offer an intermediate-term potential. It is recommended that the abyssal plain area of the EEZ be explored for nodule potential.

Phosphorite deposits are widespread on seamounts and ridges within the EEZ and occur in association with the iron-manganese crusts. The phosphorite deposits are high grade, but the tonnage of the deposits is not known. More detailed studies are required to evaluate the resource potential of this deposit type in the Kingman-Palmyra EEZ, which may offer an intermediate- to long-term resource potential.

Insular phosphorite deposits on Kingman Reef and Palmyra Atoll are unknown, but the conditions are appropriate for phosphorite to occur. An exploration program for insular and lagoonal phosphorites should include drilling on the islands and in the lagoons. Discovery of rich phosphorite deposits could have an immediate economic impact if the need was great enough. However, the recent (2001) placement of Kingman Reef and Palmyra Atoll within the National Wildlife Refuge system means that any identified resource would not be mined except in the case of extreme need.

Hydrothermal iron and manganese deposits are likely to occur scattered throughout the region, but as yet have only been sampled at one location (see fig. 15). This deposit type may have a long-term resource potential.

Shallow-water and insular aggregate for construction on Palmyra consists of sand and gravel composed of coral and shell. Construction materials are ubiquitous on the atoll, which is predominantly composed of unconsolidated sand, gravel, and reef deposits. Extensive use of construction materials occurred during World War II. The U.S. Navy dredged a seaplane runway between middle and eastern lagoons, built causeways on reef flats, and constructed a 1.8-kilometer-long runway. Exploration for lagoonal and nearshore sand and gravel are likely to identify significant deposits that can be used for local construction. Nearshore deposits would be limited to the submerged reef terrace surrounding the atoll and within the lagoons. In general, location of construction materials on this type of island is relatively easy. Identifying deposits where exploitation will not accelerate land loss or shoreline erosion, nor result in permanent habitat loss, is difficult. Armor stone for use 
in revetments and shore protection can be mined from the reef flat and from beachrock deposits. Because there is no significant land mass associated with Kingman Reef, it is unlikely that construction materials of economic significance will be identified there.

Shallow- to deep-water precious coral likely occurs on seamounts and ridges in the Kingman-Palmyra EEZ. Bamboo coral was collected during cruises dedicated to the study of iron-manganese crusts. The distribution, abundance, and resource potential of precious coral are unknown in the Kingman-Palmyra EEZ. Shallow-water black coral species typically occur in areas of steep rock faces swept by strong currents in water depths greater than 20 meters. Kingman-Palmyra has numerous sites that fit these criteria. Palmyra has at least three times the number of coral species found in Hawai'i and the Caribbean and five times the number found in the Florida Keys. It is likely that precious corals will be found among those species. A systematic exploration program is needed to delineate this potential resource. If important deposits are found, they could have an immediate economic market.

\section{Summary}

Aggregate, precious coral, and insular and lagoonal phosphorite could have an immediate economic market if significant deposits are found. Cobalt-rich crusts are high grade, but their tonnage is not known. Iron-manganese crusts and nodules may offer an intermediate-term resource potential. The other deposit types represent long-term or unknown resource potentials. Research to determine the distribution, grade, and tonnage of the above mentioned near- and intermediate-term potential resources is recommended. Research in the area west of Palmyra Atoll will be limited because of its past use as an explosives dump site. In addition, the designation of Kingman-Palmyra as a National Wildlife Refuge will limit activity in the vicinity of the island.

\section{Selected References}

Davis, A.S., Gray, L.B., Clague, D.A., and Hein, J.R., 2002, The Line Islands revisited; new ${ }^{40} \mathrm{Ar} /{ }^{39} \mathrm{Ar}$ geochronologic evidence for episodes of volcanism due to lithospheric extension: Geochemistry, Geophysics, Geosystems, v. 3, no. 3, 10.1029/2001GC000190, 28 p.

Guild, K.M., Lee, M.P., Corvalan, D.J., Dawson, K.M., Paidakovich, M.E., Salas, S.J., Piper, D.Z., Swint, T.R., Sullivan, L.G., McKelvey, V.E., Mizuno, A., Younse, G.A., 1984, Mineral-resource map of the circum-Pacific region, northeast quadrant, Tulsa, Oklahoma, America Association of Petroleum Geologists, Circum-Pacific Map Project, 1 sheet, 1:10,000,000 scale.

Halbach, P., Manheim, F.T., and Otten, P., 1982, Co-rich ferromanganese deposits in the marginal seamount regions of the Central Pacific Basin-results of the Midpac '81: Erzmetall, v. 35, p. 447-453.

Hein, J.R., Manheim, F.T., Schwab, W.C., and Davis, A.S., 1985, Ferromanganese crusts from Necker Ridge, Horizon Guyot, and S.P. Lee Guyot; geological considerations: Marine Geology, v. 69, p. 25-54.

Hein, J.R., Manheim, F.T., Schwab, W.C., Davis, A.S., Daniel, C.L., Bouse, R.M., Morgenson, L.A., Sliney, R.E., Clague, D., Tate, G.B., and Cacchione, D.A., 1985, Geologic and geochemical data for seamounts and associated ferromanganese crusts in and near the Hawaiian, Johnston Island, and Palmyra Island Exclusive Economic Zones: U.S. Geological Survey Open-File Report 85-292, 129 p.

Hein, J.R., Koschinsky, A., Bau, M., Manheim, F.T., Kang, J.-K., and Roberts, L., 2000, Cobalt-rich ferromanganese crusts in the Pacific, in Cronan, D.S., ed., Handbook of marine mineral deposits: Boca Raton, Florida, CRC Press, p. 239-279.

Manheim, F.T., and Lane-Bostwick, C.M., 1989, Chemical composition of ferromanganese crusts in the world ocean; a review and comprehensive database: U.S. Geological Survey Open-File Report 89-020. 


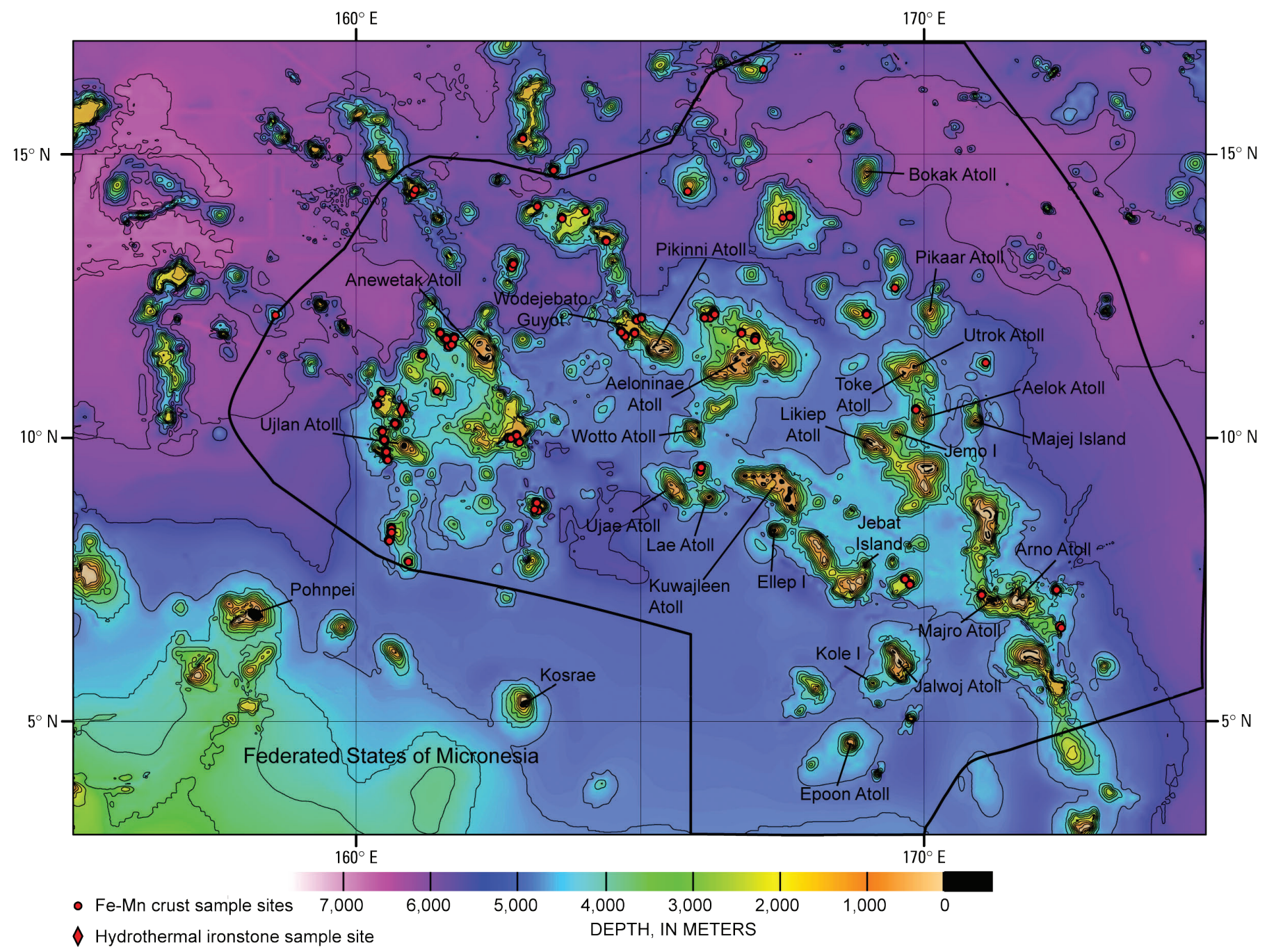

Figure 16. Bathymetric map of the Exclusive Economic Zone (EEZ) of the Republic of the Marshall Islands ("H" on fig.1); black line shows EEZ boundary. Contour interval is 500 meters. The Federated States of Micronesia, Wake Atoll, Kiribati, and Nauru EEZs border the Republic of the Marshall Islands EEZ to the west, north, southeast, and south respectively. The Marshallese spellings are used for atoll and seamount names. 


\section{Republic of the Marshall Islands}

Land area:
EEZ area:

Political status:

Population: Island minerals:

\author{
$181 \mathrm{~km}^{2}$ (29 atolls; 5 islands) \\ 2,131,000 km² (see fig. 16); \\ location shown by "H" on \\ figure 1 \\ Independent nation in free \\ association with the United \\ States \\ 58,800 (2003 estimate) \\ Insular phosphate/guano \\ deposits; aggregate
}

Note: The Marshallese spellings are used for atoll and seamount names.

\section{Island History}

The Marshall Islands are part of Micronesia, which was populated by migrants from the Malaysian-Indonesian area thousands of years ago. Several atolls were visited by the Spanish in the early and middle 1500s, and the islands were subsequently claimed by Spain in 1592 but were thereafter left more or less alone for nearly 300 years. Germany took over administration of the Marshall Islands in 1885 and developed trading stations on Jalwoj and Epoon Atolls to support a flourishing copra (dried coconut) trade. Traditional Marshallese high chiefs (Iroij) ruled under indirect colonial German administration.

At the beginning of World War I, Japan took control of the Marshall Islands, first under civil and later under naval administration. Japan's headquarters were located on Jalwoj Atoll. U.S. military troops took control from the Japanese in early 1944 following major battles on Kuwajleen and Anewetak Atolls. In 1947, the United States entered into agreement with the U.N. Security Council to administer the islands formerly administered by the Japanese. The new agreement was known as Trust Territory of the Pacific Islands (TTPI), of which the Marshall Islands were a part. The United States undertook nuclear testing on Pikinni and Anewetak Atolls from 1946 to 1958, with 69 test detonations. On May 1, 1979, the United States recognized the Constitution of the Marshall Islands and the establishment of the Government of the Republic of the Marshall Islands. After nearly forty years of U.S. administration as a U.N. Trust Territory of the Pacific Islands, the Marshall Islands attained independence on October 21, 1986, under a Compact of Free Association signed by President Ronald Reagan on that date. Under the Compact, the U.S. will continue use of the Kuwajleen Atoll missile test range for at least 30 years.

\section{Geography}

Most of the Marshall Islands are atolls with low coral limestone and sand islets located between an outer barrier reef and a central lagoon. More than 1,200 islets make up the atolls. Some of the lagoons are huge. Kuwajleen, which is used as a U.S. missile test range, has the largest lagoon $(2,174$ square kilometers) in the world and encompasses about 90 islets. The lagoons of the atolls have maximum water depths of about 10 to 100 meters. The highest elevation in the Marshall Islands is about 10 meters, which is located on Likiep Atoll. The atolls and islands are situated in two almost parallel northwest-southeast chains known as the Ratak (Sunrise) and Ralik (Sunset) groups.

\section{Geologic Setting}

The Marshall Islands EEZ consists predominantly of huge Cretaceous-age volcanic complexes, 34 of which are capped by atolls and reefs. However, most are seamounts with summits submerged from about 900 to 2,100 meters below sea level. Most of the seamounts are flat-topped guyots. Some of the seamounts are capped by submerged reefs, while others are capped by carbonate sediment, such as the large Wodejebato Guyot. Still others have volcanic rocks exposed at the surface. At least 100 small- to medium-size seamounts and 12 huge seamounts, or seamount complexes, occur within the EEZ. The measured areas of 19 guyots in the EEZ vary from 313 to 4,776 square kilometers. Conical seamounts are typically much smaller. Of 15 that have been measured, all are between 505 and 793 square kilometers in area. Many seamounts in the EEZ have been dated, with ages ranging from 140 to 68 million years. These extinct volcanoes, formed by hot-spot volcanism, delineate at least four separate hot-spot traces.

The five islands in the Marshall Islands that are not atolls (Jemo, Majej, Kole, Jebat, Ellep) are low-lying carbonate platforms surrounded by fringing reefs. These reef islands are probably partly drowned atolls composed of a still emergent islet around which a fringing reef developed. The reef and limestone caps vary from about 350 to 1,400 meters thick, under which is volcanic bedrock.

The remainder of the EEZ is sediment-covered abyssal plain, which is located adjacent to the southwest, west, north, northeast, and east EEZ boundaries (fig. 16). Nine research cruises by U.S., Korean, Japanese, and German ships have been carried out within the Marshall Islands EEZ in search of cobalt-rich iron-manganese crusts. Phosphorite and bamboo coral were also collected incidentally on those research cruises. Cobalt-rich crusts are typically much thinner on the flanks of atolls than on the summits and flanks of seamounts. This is because reef debris from the atolls continually moves down the flanks by gravity processes, disturbing the ocean floor. The crusts must then begin new growth. Consequently, seamounts within the EEZ offer a much greater potential for thick crusts than the flanks of atolls. 


\section{Offshore Mineral Deposits of the Marshall Islands}

The Marshall Islands EEZ is the most extensively sampled and studied region in the Pacific Ocean for cobaltrich iron-manganese crusts and seamount phosphorite. It has been systematically sampled and studied at many sites (see fig. 16). However, other mineral deposit types have not been systematically surveyed in the EEZ. A detailed bathymetric map of the Marshall Islands EEZ is available from the USGS on the web athttp://geopubs.wr.usgs.gov/map-mf/ $\mathrm{mf} 2324 /)$. The Marshall Islands shares its EEZ boundary to the south with Kiribati and Nauru, to the southwest with the Federated States of Micronesia, and to the north with the U.S. Territory of Wake. Within the EEZ of the Marshall Islands occur potential immediate- to long-term mineral resources. Mineral deposits that do, or should occur within the EEZ include:

- Cobalt-rich iron-manganese crusts on seamounts and island flanks

- Iron-manganese nodules on deep abyssal plains

- Phosphorite deposits on seamounts and island flanks

- Insular and lagoonal phosphorite on atolls

- Hydrothermal iron and manganese deposits on sea mounts and island flanks

- Shallow-water sand and gravel (aggregate) near and on islands

- Shallow- to deep-water precious coral on seamounts and island flanks

Cobalt-rich iron-manganese crusts have been extensively studied within the Marshall Islands EEZ. This EEZ contains widespread crust deposits with high contents of cobalt and nickel and the highest individual and mean platinum and tellurium contents when compared to crusts from other Pacific EEZs. Both thickness and grade of crusts on many seamounts exceed cut-off levels for potential mining (see appendix 2). A compilation of USGS chemical data for 116 crust samples from 15 seamounts gives mean cobalt, nickel, and copper contents of $0.64,0.46$, and 0.10 percent, respectively, whereas a compilation of Japanese data for 310 samples from nine seamounts gives mean cobalt, nickel, and copper contents of 0.73 , 0.58 , and 0.11 percent, respectively. In addition, titanium, molybdenum, zirconium, and cerium contents are very high in the USGS data set.

The thickest crusts occur within saddles in the summit region or along summit margin platforms of seamounts. The Marshall Islands EEZ has one of the best potentials for this resource among the Pacific islands EEZs. These deposits represent a near- to intermediate-term resource potential for cobalt, nickel, platinum, and possibly other metals. Additional exploration in needed to better delineate the locations of thick and high-grade crusts, but the greater need is to map in detail the small-scale topography of seamounts that have previously been the most extensively sampled.
Iron-manganese nodules occur on the sediment surface of the deep-water abyssal plains. Very little work has been done on these deposits, and nodule distribution and grade are poorly known. However, immediately to the east, in the Central Pacific Basin, is a broad area with perhaps the highest documented nodule coverage known. If areas of favorable nodule density and favorable grades can be located within the EEZ, these nodules would offer an intermediate-term potential.

Phosphorite deposits are widespread on seamounts and island flanks within the EEZ and occur in association with the iron-manganese crusts. Phosphorites were sampled during all the research cruises to the Marshall Islands EEZ. These deposits are high grade and cover extensive areas. Iron-Manganese crusts in the EEZ have a higher mean phosphorus content than crusts from other EEZs. This relationship should be an indicator of the amount of seamount phosphorite, because the source of the phosphorous was the same for both. Additional exploration is recommended, even though this deposit type may only have a long-term resource potential.

Insular/lagoonal phosphorite deposits are found on a number of Marshall Islands atolls, including Arno, Pikaar, Ujlan, Wotto, Ujae, Toke, Epoon, and Kuwajleen, as well as on Jemo Island. Samples from Epoon, Pikaar, and Arno Atolls average 38.5 percent, 23.7 percent, and 12.6 percent $\mathrm{P}_{2} \mathrm{O}_{5}$, respectively. These phosphates are generally thin $(<30$ centimeters) and occur as a hardpan immediately below a humusrich soil layer in what is called "Jemo soil." These deposits may not be large enough to be of economic importance, but they may serve as a local source of fertilizer for farms. The lagoons of most Marshall Islands atolls are perhaps too large and too deep to host lagoonal phosphorite deposits. The few atolls with relatively shallow lagoons, such as Bokak, and the reef islands may host insular and lagoonal phosphorite and warrant further exploration.

Hydrothermal iron and manganese deposits are likely to occur scattered throughout the region and have been sampled at two locations (fig. 16). This deposit type may have a long-term resource potential.

Shallow-water and insular aggregate for construction consists of sand and gravel composed of coral and shell. Construction materials are ubiquitous on the atolls, which are predominantly composed of unconsolidated sand, gravel, and reef deposits. Sand and fine gravel usually occur on the beaches, bars, lagoon sand aprons, lagoon floors in general, and the unconsolidated parts of islets. Gravel is found on beaches and beach ridges seaward of the windward islets and lagoonward of the leeward islets, as well as on beaches and ridges along channels between islets. Extensive use of construction materials occurs (or has occurred) on many of the atolls, especially those with military activities or with large populations centers, such as Majro, Kuwajleen, Anewetak, Pikinni, and Arno Atolls. Sand and gravel deposits have been mapped on the islets and offshore at these five atolls and are abundant on the islets, in the nearshore ( $<10$ meters), and within the deeper lagoons. In addition, sand and gravel have been studied on the islets of Bokak, Pikaar, Aelok, Lae, Likiep, Toke, Ujae, Ujlan, 
Utrok, and Wotto Atolls. Construction has been and continues to be extensive on Majro and Kuwajleen, where local sources of aggregate have been used. Reef channels have been blasted and dredged, sand aprons and lagoon bottoms dredged, islets and reef platforms mined and modified, and piers and jetties built. The nuclear tests on Kuwajleen and Anewetak produced areas of finer-grained sand sediment than is found naturally on the lagoon floors. Exploration for lagoonal and nearshore sources of sand and gravel on other atolls is likely to identify significant deposits. Armor stone for use in revetments and shore protection can be mined from the reef flat and from beachrock deposits, which are common on the Marshall Islands atolls and islands. In general, construction materials on these types of atolls are abundant, but it is difficult to identify deposits where exploitation will not accelerate land loss or shoreline erosion, nor result in permanent habitat loss.

Shallow- to deep-water precious coral likely occurs on seamounts and island flanks within the Marshall Islands EEZ. Bamboo coral was collected in many dredges that sampled crusts and phosphorite. It has been estimated that about 68 of 76 genera of Scleractinia corals that occur in Oceania occur in the Marshall Islands EEZ. However, the distribution, abundance, and resource potential of precious corals are unknown. Shallow-water black coral species typically occur in areas of steep rock faces swept by strong currents in water depths greater than 20 meters. Marshall Islands atolls, islands, and seamounts have numerous potential sites where precious corals should be found. A systematic exploration program is needed to delineate this potential resource. If important deposits are found, they could have an immediate economic market.

\section{Summary}

Aggregate and precious coral could have an immediate economic impact if significant deposits and markets are found. Significant cobalt-rich crust deposits occur throughout the EEZ, and such crusts, along with iron-manganese nodules, may offer a near- to intermediate-term resource potential. The other deposit types represent long-term or unknown resource potentials. Reconnaissance cruises dedicated to understanding the distribution, grade, and tonnage of precious coral and iron-manganese nodules and additional cruises to define the crust and phosphorite resources are recommended. Exploratory drilling for insular and lagoon phosphorites is also warranted.

\section{Selected References}

Fosberg, F.R., and Carroll, D., 1965, Terrestrial sediments and soils of the northern Marshall Islands: Atoll Research Bulletin, v. 113, $156 \mathrm{p}$.

Hein, J.R., 2004, Cobalt-rich ferromanganese crusts; global distribution, composition, origin and research activities, in Minerals other than polymetallic nodules of the International Seabed Area: Kingston, Jamaica, International Seabed Authority, Proceedings of a workshop held on 26-30 June 2000, volume 1, p. 188-256.

Hein, J.R., Schwab, W.C., and Davis, A.S., 1988, Cobaltand platinum-rich ferromanganese crusts and associated substrate rocks from the Marshall Islands: Marine Geology, v. 78 , p. $255-283$.

Hein, J.R., Kang, J-K., Schulz, M.S., Park, B-K., Kirschenbaum, H., Yoon, S-H., Olson, R.L., Smith, V.K., Park, D-W., Riddle, G.O., Quinterno, P.J., Lee, Y-O., Davis, A.S., Kim, S.R., Pringle, M.S., Choi, D-L., Pickthorn, L.B., Schlanger, S.O., Duennebier, F.K., Bergersen, D.D., and Lincoln, J.M., 1990, Geological, geochemical, geophysical, and oceanographic data and interpretations of seamounts and Co-rich ferromanganese crusts from the Marshall Islands, KORDI-USGS R.V. Farnella Cruise F10-89-CP: U.S. Geological Survey Open-File Report 90-407, 246 p.

Hein, J.R., Moon, J.-W., Lee, K.-Y., Kim, K.-H., Roberts, L., Burrows, M., Park, S.H., Dowling, J., Choi, Y.-J., Zielinski, S.E., Chi, S.-B., Benninger, L., Kim, H.-S., and Park, C.-K., 1998, Composition of Co-rich ferromanganese crusts and substrate rocks from the Marshall Islands, Cruise KODOS 97-4: U.S. Geological Survey Open-File Report 98-375, 71 p. Hein, J.R., Moon, J.-W., Lee, K.-Y., Dowling, J.S., Kim, K.-H., Burrows, M., Park, S.H., Choi, Y.-J., Schuetze, A.A., Jung, H.S., Kin, H.-S., Lee, G.C., Park, C.-K., Son, S.K., and Park, C.Y., 1999, Co-rich Fe-Mn crusts from the Marshall Islands (Leg 1) and hydrothermal and hydrogenetic Fe-Mn deposits from Micronesia (Leg 2), KODOS 98-3 cruise, West Pacific: U.S. Geological Survey Open-File Report 99-412, 63 p.

Hein, J.R., Wong, F.L., and Mosier, D.L., 1999, Bathymetry of the Republic of the Marshall Islands and vicinity: U.S. Geological Survey Miscellaneous Field Studies Map MF2324, version 1.0, 1 sheet, scale 1:2,000,000 (and web page http://geopubs.wr.usgs.gov/map-mf/mf2324/).

Hein, J.R., Koschinsky, A., Bau, M., Manheim, F.T., Kang, J.-K., and Roberts, L., 2000, Cobalt-rich ferromanganese crusts in the Pacific, in Cronan, D.S., ed., Handbook of marine mineral deposits: Boca Raton, Florida, CRC Press, p. 239-279.

Koppers, A.A.P., $1998,{ }^{40} \mathrm{Ar} /{ }^{39} \mathrm{Ar}$ geochronology and isotope geochemistry of the West Pacific Seamount Province: Unpublished Ph.D. dissertation, Vrije University, The Netherlands, $263 \mathrm{p}$.

Piper, D.Z., Swint-Ike, T.R., and McCoy, F.W., 1987, Distribution of ferromanganese nodules in the Pacific Ocean: Chemie der Erde, v. 46, p. 171-184.

Stoddart, D.R., and Scoffin, T.P., 1983, Phosphate rock on coral reef islands, in Goudie, A.S., and Pye, K., eds., Chemical sediments and geomorphology: London, Academic Press, p. 369-400. 


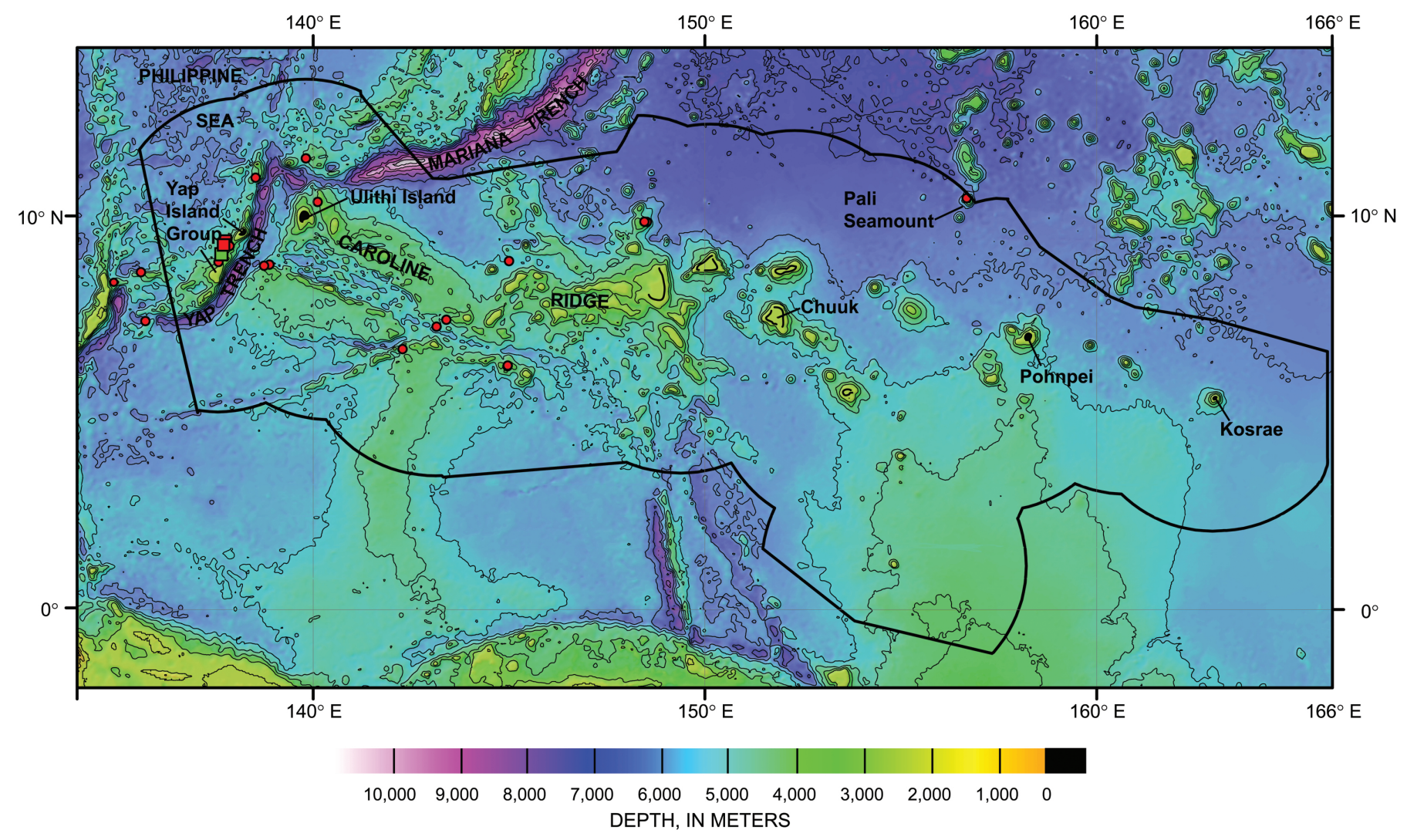

- Fe-Mn crust sample sites

$\square$ Sample sites with both Fe-Mn crusts and hydrothermal Mn

$\square$ Hydrothermal Mn sample site

Figure 17. Bathymetric map of the Exclusive Economic Zone (EEZ) of the Federated States of Micronesia (“I" on fig.1); black line shows EEZ boundary. Contour interval is 500 meters. The Belau, Guam, and Republic of the Marshall Islands EEZs border the Federated States of Micronesia EEZ to the west-southwest, north, and northeast, respectively. 


\section{Federated States of Micronesia}

Land area:
EEZ area:

Political status:

Population: Island minerals:

\author{
$702 \mathrm{~km}^{2}$ (607 islands) \\ 2,978,000 km² (see fig. 17); \\ location shown by "I" on \\ figure 1 \\ Independent nation in free \\ association with the United \\ States \\ 108,155 (July 2004 estimate) \\ Phosphate/guano deposits, \\ gold, copper, bauxite, \\ aggregate
}

\section{Island History}

The earliest settlement of greater Micronesia is thought to have occurred about 2,000 years ago on the western mountainous islands, with immigrants arriving from the south. Yap may possibly have been settled even earlier, its language suggesting settlers from more varied areas, possibly from the west as well. In 1525, Portuguese explorers encountered Yap and Ulithi Islands during their search for the Spice Islands (Indonesia). Spanish expeditions later made the first European contact with the rest of what came to be known as the Caroline Islands. Spain claimed sovereignty over the Caroline Islands from 1886 to 1899. When Spain withdrew from its Pacific insular areas, they were sold to Germany, except for Guam, which became a U.S. insular area. Germany administered the islands from 1899 to 1914 , when Japanese naval squadrons took military possession of the Marshall, Caroline, and Northern Mariana Islands. Japan began its formal administration by a League of Nations mandate in 1920.

The U.N. created the Trust Territory of the Pacific Islands (TTPI) in 1947. The Federated States of Micronesia (FSM), along with Palau, the Marshall Islands, and the Commonwealth of the Northern Mariana Islands together constituted the TTPI. The TTPI came under United States Department of the Interior administration in 1951. The U.S. President appointed a High Commissioner to administer the Trust Territory, who in turn appointed a district administrator for each of the FSM States until 1979. In that year, the United States recognized the FSM constitution and the establishment of the Government of the FSM at both national and state levels. FSM became an independent nation in November 1986, at which time the Compact of Free Association with the United States was established. The Kosrae, Pohnpei (formerly Ponape), Chuuk (formerly Truk), and Yap island groups now make up the four states of the FSM.

\section{Geography}

The 607 islands that constitute the FSM vary from high mountainous islands to low-lying coral atolls. Yap is the westernmost state, and has a total land area of 118.9 square kilometers and lagoon area of 1,049 square kilometers. Chuuk consists of seven major island groups, the largest being Chuuk proper. It is a complex of 98 islands, 14 of which are volcanic, surrounded by a barrier reef enclosing 2,072 square kilometers of lagoon. Pohnpei is mountainous, with 342.4 square kilometers of land area and 769.7 square kilometers of lagoon. The impressive ruins at Nan Mandol on islets off southeastern Pohnpei date from about A.D. 1200. This extensive array of ancient structures was constructed from columnar basalt quarried on the main island. Kosrae has 111.9 square kilometers of land and no lagoon. More than half of the population of approximately 108,000 lives in Chuuk State. The cultures are as varied as the geography, and eight different languages are spoken.

The major islands of each state are the erosional remnants of long inactive volcanoes, now partially submerged. The degree of submergence has determined in part the type of reef surrounding the islands. Kosrae has a fringing reef with no inner lagoon. The Chuuk group of islands sits atop a submerged shield volcano, with a triangular lagoon approximately 55 kilometers on a side. Within the lagoon are numerous coral and volcanic islands, the latter rising as much as 442 meters above sea level, some with fringing reefs. The coral islands within the lagoon and at the margins of the lagoon rise only about one meter above sea level. The Yap islands consist of an elongate, approximately 24-kilometer-long, partially submerged and eroded volcanic edifice, encompassed by a fringing- to barrier-reef and lagoon complex. Pohnpei is a high volcanic island that hosts the highest peaks in the FSM: Totolom (Dolohmwar) at 791 meters and Mt. Nahna Laud at 798 meters.

Gold mineralization occurs in epithermal quartz veins and breccia and in hydrothermal iron oxide/silica rocks on Maap (also spelled Map) and on the Gagil-Tamil Islands in the Yap island group. Gold grades up to about 4 grams per ton have been determined. About 4,000 metric tonnes of copper ore, averaging 5.2 percent copper, was mined near Onean and Gatjapar on Gagil-Tomil Island and at Talangith on Maap Island during Japanese occupation. During that time, 12,700 metric tonnes of nickel-rich laterite, averaging 0.7 percent nickel and 44 percent iron, was mined from an open pit at Gatjapar.

\section{Geologic Setting}

The FSM EEZ can be divided into two broad geologic provinces. The first is a complex array of ancient volcanoes and ridges that makeup the 2,500-kilometer-long Caroline Ridge. The second is a volcanic-arc-subduction zone system comprising the Yap Trench, Yap Arc, Philippine Sea backarc area, and the southern margin of the Mariana arc-trench 
system. In addition, among these topographic high areas and at the margins of the EEZ occur regions of sediment-covered abyssal plain.

The Caroline Ridge can be further divided into eastern, central, and western sections that have distinct geologic characteristics. The eastern third of the ridge extends from Kosrae Island to Chuuk Atoll and trends northwestward. This segment consists of isolated atolls and seamounts and represents the trace of a hot spot that was active between 12 million and 1 million years ago. The central segment extends westward from Chuuk Atoll to Ifalik Atoll-Tarang Bank. This segment consists of large carbonate banks and atolls and is generally of water depths less than 2,500 meters. The western third of Caroline Ridge extends from Ifalik Atoll to the Yap trench and trends northwestward. This segment consists of a large shallow-water $(<2,500$ meters) ridge bounded by, and cut by, narrow troughs that represent strike-slip faults (southern margin), normal faults (northern margin), and small spreading basins. Both the north and south flanks are block faulted. The origin of the western two-thirds of Caroline Ridge is not certain. That region has been variously interpreted as a relict island arc, a leaky transform fault, a leaky transform fault combined with a hot-spot trace, and an extinct spreading ridge/ transform fault system. The central and western parts of the ridge are about 28 to 24 million years old.

The Yap Arc and Trench represent an Oligocene through Neogene (34-1.8 million years old) subduction margin, but one that is distinct in many ways from other west and southwest Pacific arcs, such as the Mariana Arc. For example, the distance between the arc summit and trench axis is very small and subduction may have ended in the late Miocene. Also, many of the rocks recovered from the arc (inner trench wall, summit, and summit islands) are metamorphic rocks. Many of the volcanic rocks have a compositional signature of oceanic crust and thus may be obducted oceanic crust. Rocks dredged from the outer trench slope have a mid-ocean ridge basalt (MORB)-like composition and are about 7 million years old. Other rocks are more typical of volcanic arcs. It has been suggested that subduction ended in the late Miocene and that back-arc basin crust was obducted onto the volcanic arc. However, these suggestions are difficult to reconcile with the occurrence of hydrothermal mineralization of Quaternary $(<1.8$ million years old $)$ sandstone at the summit of the Yap Arc.

\section{Offshore Mineral Deposits of the FSM}

Cobalt-rich iron-manganese crusts were sampled at several sites within the FSM EEZ, and hydrothermal manganese within the Yap Arc part of the EEZ, during joint U.S.-Korean and Japanese research cruises (fig. 17). Other mineral deposit types have not been systematically surveyed in the EEZ. Immediate- to long-term potential mineral resources may occur within the EEZ of the FSM. Mineral deposits that do, or are likely to occur within the EEZ include:

\footnotetext{
- Cobalt-rich iron-manganese crusts on seamounts and ridges
}

- Iron-manganese nodules on the deep abyssal plains

- Phosphorite deposits on seamounts near the eastern EEZ margin

- Insular and lagoonal phosphorite

- Hydrothermal iron and manganese deposits along the Yap Arc

- Epithermal gold and base metal deposits along the Yap Arc

- Skarn deposits on Caroline Ridge

- Shallow-water sand and gravel (aggregate)

- Shallow- to deep-water precious coral on seamounts, ridges, and island flanks

Cobalt-rich iron-manganese crusts have been moderately well studied within the FSM EEZ. This EEZ contains widespread crust deposits with moderate contents of cobalt (mean 0.40 percent), nickel ( 0.35 percent), and copper (0.09 percent) and low platinum contents ( 0.22 grams per ton). The crusts are generally thin, averaging less than 20 millimeters on most seamounts sampled. Samples collected from Pali seamount (fig. 17) indicate that crusts may be thicker and of higher grade on seamounts in the north and northeastern sectors of the EEZ. The Pali seamount crusts average 50 millimeters thick, with mean contents of 0.50 percent cobalt, 0.41 percent nickel, 0.13 percent copper, and 0.30 grams per ton platinum. The reason for the generally thin crusts is the relatively young age of most of the seamounts and ridges on which the crusts grow. The low grades are partly explained by the diluting effect of detritus and hydrothermal input from the west Pacific volcanic arcs. With the available data, there is only a long-term potential for this resource, although the northern and northeastern regions of the EEZ should be further explored.

Iron-manganese nodules have been tentatively identified in a few bottom photographs. Nodules are apparently uncommon, even on the deep abyssal plains of the West Mariana Basin and Philippine Sea. It should be noted, however, that no research has been carried out in either basin to evaluate nodule potential.

Iron-manganese nodules have been recovered from Pali seamount (fig. 17). They have relatively small rock nuclei, similar to abyssal-plain nodules. The mean cobalt, nickel, and copper contents for 10 nodules are 0.43 percent, 0.47 percent, and 0.13 percent, respectively. Exploration is required for both abyssal-plain and seamount nodules in the FSM EEZ before their resource potential can be evaluated.

Phosphorite deposits likely occur on seamounts and ridges in the northern and eastern sectors of the EEZ along with iron-manganese crusts. Phosphorite has been collected on Pali, Olapahd, and Namonuito seamounts and probably occurs on other seamounts in those areas. These deposits are likely to be high grade and cover extensive areas on seamounts in those sectors. Exploration is warranted, even though this deposit type offers only a long-term resource potential.

Insular phosphorite was mined from Fais Island (a level carbonate platform) in the 1930s during Japanese occupation. 
About 50,000 tonnes per year with an average grade of 30 percent $\mathrm{P}_{2} \mathrm{O}_{5}$ was mined at the height of operations. A total of 345,000 tonnes was mined, leaving reserves of about 200,000 tonnes with a grade of 36 percent $\mathrm{P}_{2} \mathrm{O}_{5}$. Phosphate rock has also been found and analyzed from Faraulep (23.7 percent $\mathrm{P}_{2} \mathrm{O}_{5}$ ), Eauripik (34.8 percent $\mathrm{P}_{2} \mathrm{O}_{5}$ ), and Gafercut (19 percent $\mathrm{P}_{2} \mathrm{O}_{5}$ ) Atolls. Reserves on Gafercut are about 11,600 tonnes. Phosphorite has been reported to occur on Ngetik Atoll, but information about that deposit is scarce. Other phosphate deposits may occur in the FSM EEZ on atolls (for example, Oroluk, Namonuito, Murito, and Sorol), carbonate platform islands, and shallowly submerged banks (for example, Mogami Bank, Gray Feather Bank) that at one time were atolls. If high-grade lagoonal phosphate is found, the relatively deep lagoons (average 46 meters) would complicate their development. Exploration is recommended to delineate the potential resource for insular/lagoonal phosphorites.

Hydrothermal iron and manganese deposits have been sampled in three dredge hauls from the Yap Arc. Those samples have unusually high nickel (mean 0.48 percent) contents, high copper ( 0.26 percent) and zinc $(0.16$ percent) contents, and typical manganese (44 percent) contents. These deposits are likely to be small and widely scattered and have a longterm resource potential.

Gold and base metals occur in epithermal quartz veins, mineralized breccia, and iron/silica deposits in the Yap islands group. Two of six dredge hauls collected offshore the areas on the islands where gold and base-metal deposits have been found recovered vein quartz with enrichments of gold to about twice its average concentration in the Earth's crust. The recovery of vein quartz warrants a greater investigation. Location of high-grade deposits would have a short-term resource potential.

Samples of a skarn deposit were recovered in a dredge haul from Caroline Ridge ( $9^{\circ} 10.07^{\prime} \mathrm{N}$ latitude; $141^{\circ} 34.00 \mathrm{E}$ longitude). The sample consists predominately of a garnet-rich limestone. Ore deposits are commonly associated with such deposits on land, and their occurrence in the EEZ of the FSM warrants further exploration.

Shallow-water and insular aggregate for construction consists of sand and gravel composed of coral and shell. Construction materials are ubiquitous on the reef flats of the volcanic islands, as well as on the atolls and reef islands. Atolls and reef islands are composed predominantly of unconsolidated sand, gravel, and reef deposits. Sand and fine gravel usually occur on the beaches, bars, lagoon sand aprons, lagoon floors in general, and the unconsolidated parts of islets. Gravel is found on beaches and beach ridges seaward of the windward islets and lagoonward of the leeward islets, as well as on beaches and ridges along channels between islets. Use of carbonate construction materials occurs on many of the atolls and islands. In general, these types of construction materials are common on atolls and reef islands, but it is difficult to identify deposits where exploitation will not accelerate land loss or shoreline erosion, nor result in permanent habitat loss. Armor stone for use in revetments and shore protection can be mined from the reef flat and from beachrock deposits, which are common on the atolls and islands.

On the Yap Islands, building material has been dredged from Yunearawey Channel, which separates Maap and GagilTamil Islands, and dredging will likely continue there in the future. It has been proposed to dredge Yinbinaew Channel, which separates Maap and Rumung Islands, for building materials in the future. Dredging offshore of eastern Gagil near Wanyaan is being considered to recover fill for roads. Sand dredged from the northern reef flat outside Tamil Harbor is being used for the production of concrete. Other sites in the Tamil Harbor area have been mined in the past, and those near the Meqruur village causeway and near Dugor may be mined in the future. Two sites have been dredged off southern Yap Island. The site near Ngoof may be occupied again in the future. Two dredged sites on northwest Yap Island may again be mined in the future, one near Kanif and the other on Faay inlet on Miil Channel.

The high volcanic islands have ample volcanic-rock aggregate and building stone that provide a higher quality material for construction than carbonate sediment. Volcanic outcrops on Pohnpei have been studied in some detail and have yielded aggregate and building stone. The Pohnpei material consists largely of alkali basaltic lavas that are little weathered. They have been evaluated for use as coastal riprap and armor stone, fluvial hydraulic scour protection, roads and pavements, rubble and masonry walls, coastal breakwaters, coastal protection structures, and other engineering application. These rocks have good integrity, few fractures, and little weathering, making them excellent construction material.

Shallow- to deep-water precious coral likely occurs on seamounts and ridges in the FSM EEZ. However, the distribution, abundance, and resource potential of precious coral are unknown. Shallow-water black coral species typically occur in areas of steep rock faces swept by strong currents in water depths greater than 20 meters. The FSM appears to have numerous potential sites for this and other precious corals. A systematic exploration program is needed to delineate this potential resource and to provide background data needed to permit its exploitation in an environmentally sound way. If important deposits are found, they could have an immediate economic market.

\section{Summary}

Aggregate, precious coral, and epithermal gold could have an immediate economic impact if significant deposits and markets are found. Significant iron-manganese crust deposits occur throughout the EEZ, but they are generally thin and the grades are generally low. Exploration is warranted for the northern and eastern sectors of the EEZ, where the thicknesses and grades are likely to be higher. The distribution and grade of iron-manganese nodule are unknown. Crusts and nodules will likely have a long-term resource potential. The other deposit types represent long-term or unknown resource potentials. Reconnaissance cruises dedicated to understanding 
the distribution, grade, and tonnage of epithermal base-metal deposits, skarn deposits, hydrothermal deposits, and phosphorites are recommended.

\section{Selected References}

Burnett, W.C., and Lee, A.I.N., 1980, The phosphate supply system in the Pacific region: GeoJournal, v. 4, p. 423-436.

Hawkins, J., and Batiza, R., 1977, Metamorphic rocks of the Yap arc-trench system: Earth and Planetary Science Letters, v. 37, p. 216-229.

Hein, J.R., 2004, Cobalt-rich ferromanganese crusts; global distribution, composition, origin and research activities, in Minerals other than polymetallic nodules of the International Seabed Area: Kingston, Jamaica, International Seabed Authority, Proceedings of a Workshop held on 26-30 June 2000, volume 1, p. 188-256.

Hein, J.R., Ahn, J-H., Wong, J.C., Kang, J.-K., and others, 1992, Geology, geophysics, geochemistry, and deep-sea mineral deposits, Federated States of Micronesia; KORDIUSGS R.V. Farnella Cruise F11-90-CP: U.S. Geological Survey Open-File Report 92-218, 191 p.

Hein, J.R., Koschinsky, A., Halbach, P., Manheim, F.T., Bau, M., Kang, J.-K., and Lubick, N., L., 1997, Iron and manganese oxide mineralization in the Pacific, in Nicholson, K., Hein, J.R., Bühn, B., and Dasgupta, S., eds., Manganese mineralization; geochemistry and mineralogy of terrestrial and marine deposits: Geological Society of London Special Publication 119, p. 123-138.

Hein, J.R., Moon, J.-W., Lee, K.-Y., Dowling, J.S., Kim, K.-H., Burrows, M., Park, S.H., Choi, Y.-J., Schuetze, A.A., Jung, H.S., Kin, H.-S., Lee, G.C., Park, C.-K.,
Son, S.K., and Park, C.Y., 1999, Co-rich Fe-Mn crusts from the Marshall Islands (Leg 1) and hydrothermal and hydrogenetic Fe-Mn deposits from Micronesia (Leg 2), KODOS 98-3 cruise, West Pacific: U.S. Geological Survey Open-File Report 99-412, 63 p.

Hein, J.R., Koschinsky, A., Bau, M., Manheim, F.T., Kang, J.-K., and Roberts, L., 2000, Cobalt-rich ferromanganese crusts in the Pacific, in Cronan, D.S., ed., Handbook of marine mineral deposits: Boca Raton, Florida, CRC Press, p. 239-279.

Keating, B.H., Mattey, D.P., Helsley, C.E., Naughton, J.J., Epp, D., Lazarewicz, A., and Schwank, D., 1984, Evidence for a hot spot origin of the Caroline Islands: Journal of Geophysical Research, v. 89, p. 9937-9948.

Mammerickx, J., 1978, Re-evaluation of some geophysical observations in the Caroline basins: Geological Society of America Bulletin, v. 89, p. 192-196.

Rytuba, R.J., and Miller, W.R., 1990, Geology and geochemistry of epithermal precious metal vein systems in the intra-oceanic areas of Palau and Yap, western Pacific: Journal of Geochemical Exploration, v. 35, p. 413-447.

Stoddart, D.R., and Scoffin, T.P., 1983, Phosphate rock on coral reef islands, in Goudie, A.S., and Pye, K., eds., Chemical sediments and geomorphology: London, Academic Press, p. 369-400.

Usui, A., and Someya, M., 1997, Distribution and composition of hydrogenetic and hydrothermal manganese deposits in the northwest Pacific, in Nicholson, K., Hein, J.R., Bühn, B., and Dasgupta, S., eds., Manganese mineralization; geochemistry and mineralogy of terrestrial and marine deposits: Geological Society of London Special Publication 119, pp. 177-198. 
(Section on Midway Atoll begins on following pages.) 


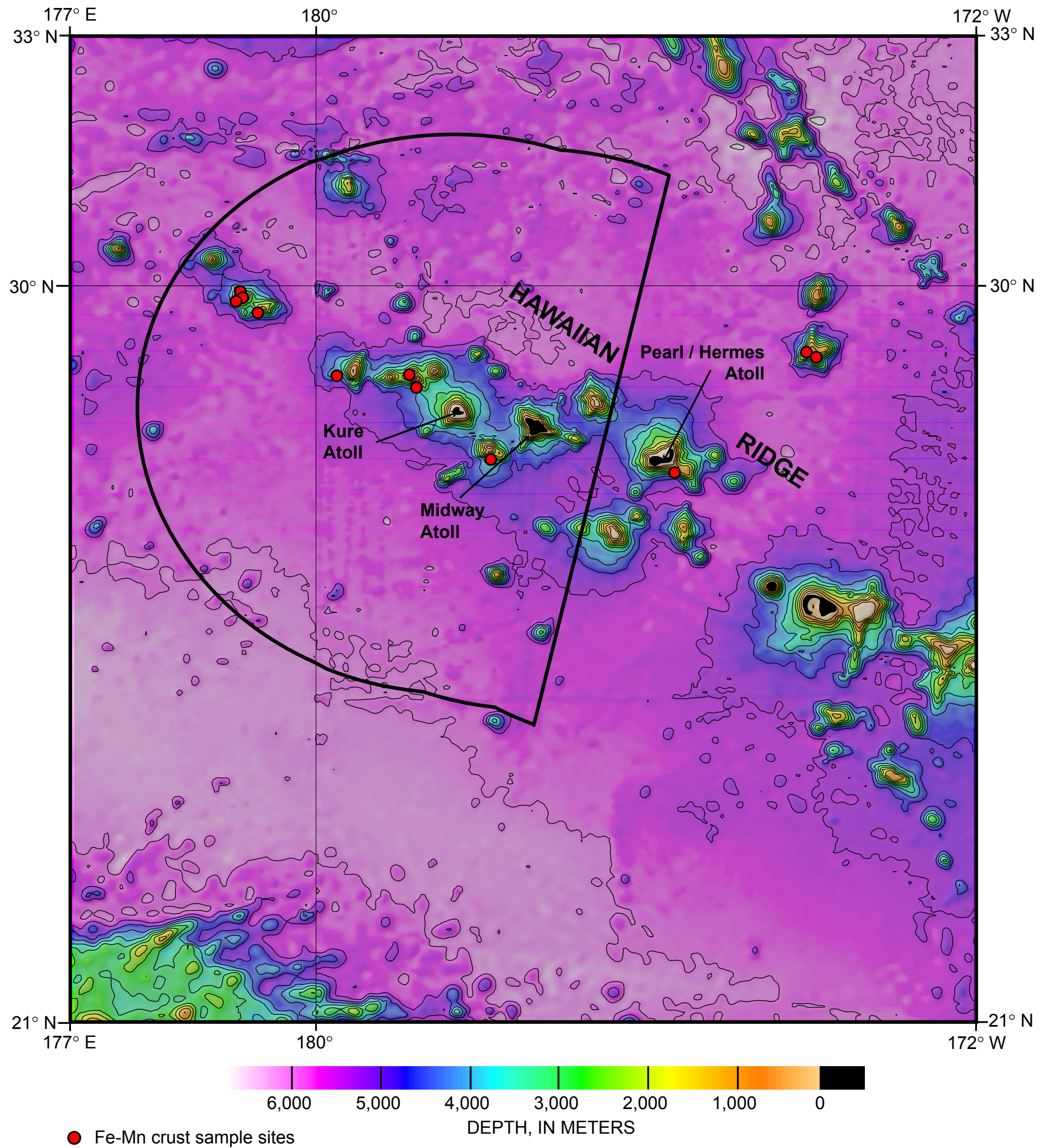

Figure 18. Bathymetric map of the Exclusive Economic Zone (EEZ) of Midway Atoll ("J" on fig.1); black line shows EEZ boundary. Contour interval is 500 meters. The Hawaiian EEZ borders the Midway Atoll EEZ to the east. 
Midway Atoll

\author{
Land area: \\ EEZ area: \\ Political status: \\ Population:
}

Island minerals:

\section{Island History}

Captain N.C. Middlebrooks (commonly known as Captain Brooks) of the Hawaiian Barque Gambia sighted Midway Island in 1859 and named it Brooks (Middlebrooks by some accounts) Island. Captain William Reynolds of the USS Lackawanna claimed the atoll as a U.S. insular area on August 28, 1867. This claim was in compliance with instructions from the Secretary of the Navy, pursuant to the Guano Act of August 18,1856 . The Navy renamed it Midway Island because of its position on the route between California and Japan. In 1903, workers for the Commercial Pacific Cable Company lived on Midway, which served as a station for the first trans-Pacific cable. From 1935 to 1941, Midway was used as a Pan American China Clipper stopover for Orient-bound flights and for the refueling of other flights. The Navy established Midway as a Naval Defense Sea Area and Airspace Reservation in 1940, a prelude to Midway's critical role in World War II. It became part of the Pacific Airborne Early Warning System in 1957 and became a Naval Air Station in 1968. In the late 1960s, about 3,500 people were living on the island in support of U.S. efforts in the Vietnam War. Military facilities were closed in stages between September 1993 and 1997. Jurisdiction and control of the atoll were transferred to the U.S. Fish and Wildlife Service as part of the National Wildlife Refuge system on October 31, 1996, through Executive Order 13022 by President William J. Clinton. Presently, 100 visitors (tourists) are allowed on the island at a time. Its current political status is as an unincorporated insular area.

\section{Geography}

Midway Atoll is about 2,100 kilometers northwest of Honolulu, Hawaii. The atoll is 8 to 10.5 kilometers in diameter and consists of two large islets, Sand and Eastern Islands, which have a total area of just under 6.2 square kilometers and a maximum elevation of 13 meters. Several smaller islets also cap the atoll rim. A single reef passage occurs along the south rim and several passages are situated along the northwest rim.
In general, the lagoon is shallow; however, basins as deep as $21 \mathrm{~m}$ occur in the central part. Several other atolls occur near Midway Atoll, including Kure Atoll, 93 kilometers to the northwest and the last island in the Hawaiian chain, and Pearl and Hermes Reef (Atoll), 167 kilometers to the southeast, also part of the Hawaiian chain. The eastern boundary of the Midway EEZ is shared with the Hawaiian Islands National Wildlife Refuge, which extends from Nihoa Island through Pearl and Hermes Atoll.

\section{Geologic Setting}

Midway Atoll is part of the 2,500-kilometer-long Hawaiian Ridge, a chain of islands and seamounts extending from Kure Atoll at the northwestern end to the island of Hawai' $i$ at the southeastern end. The sea-floor topography within the central third of the Midway EEZ is characterized by large volcanic edifices about 28 million years old built on ocean crust about 110 million years old. The oldest volcanic rocks recovered from the submerged flanks of Midway are about 28 million years old, but volcanism occurred intermittently at Midway until about 11 million years ago. The volcanic edifice underlying Midway Atoll extended above sea level in earliest Miocene time ( $\sim 24$ million years ago). Subsidence carried it below sea level, resulting in the development of a shallow swamp-like environment that was followed by the introduction of coral and other marine life. Continued subsidence culminated in the present coral-atoll structure. The period of submergence and coral growth was interrupted several times by intervals of emergence. On the basis of two drill cores, the top of the extinct basaltic volcano now lies from about 150 meters below sea level on the south side to 380 meters below sea level on the north side.

Deep-water abyssal plains cover most of the northern third and southern third of the EEZ. Seamounts are sparsely distributed in these areas.

\section{Offshore Mineral Deposits of Midway Atoll}

Within the EEZ of Midway Atoll occur immediate- to long-term potential mineral resources. Mineral deposits that do, or are likely to occur within the EEZ include:

- Cobalt-rich iron-manganese crusts on volcanic edifices

- Iron-manganese nodules on the deep-water abyssal plains

- Phosphorite deposits on volcanic edifices

- Insular and lagoonal phosphorite on atolls and islands

- Hydrothermal iron and manganese deposits on seamounts

- Shallow-water sand and gravel (aggregate) on and adjacent to atolls and islands

- Shallow- to deep-water precious coral on sea mount island flanks 
Cobalt-rich iron-manganese crusts have been relatively extensively studied within the U.S. EEZ around the entire Hawaiian chain of islands. That EEZ contains widespread crust deposits with high contents of cobalt and titanium, moderate nickel, and low platinum. The U.S. Minerals Management Service completed an environmental impact statement for crust mining in the EEZ of Hawaii. In contrast, a relatively small number of samples (25) have been collected from the Midway EEZ. Analyses of those samples yield mean cobalt, nickel, and copper contents of 0.88 percent, 0.42 percent, and 0.05 percent, respectively. That mean cobalt content is much higher than that of the Hawaiian EEZ (0.69 percent), which is based on the analysis of 182 samples. However, the Midway EEZ deposits will likely have only an intermediate- to longterm resource potential for cobalt, nickel, and possibly other metals, because the seamounts are relatively small and the crusts are generally less than $20 \mathrm{~mm}$ thick. The National Wildlife Refuge status of much of the region would limit the likelihood of mining as well.

Iron-manganese nodules occur on the sediment surface of the deep-water abyssal plain. Little work has been done on these deposits, and nodule distribution and grade are poorly known. However, GLORIA side-scan sonar images of the sea floor indicate that nodule coverage may be extensive. On the abyssal plain to the south, outside the EEZ, the average sediment accumulation rate is very slow, which favors extensive nodule coverage. If areas of favorable nodule density and favorable grades are located within the Midway EEZ, these nodules would offer an intermediate-term potential.

Phosphorite deposits are widespread on seamounts and ridges within the EEZ and occur in the same places as the iron-manganese crusts. These deposits are typically either small, high-grade deposits or more widespread, low-grade deposits. This deposit type may have a long-term resource potential.

Insular phosphorite deposits are known to occur on Midway Atoll, which was originally acquired by the United States in 1867 under the Guano Act. However, phosphate has not been mined from the atoll. Phosphorite likely occurs on other atolls, islands, reefs, and banks in the area, because conditions are favorable for its formation. The potential for lagoonal phosphorite is unknown. A drilling program in 1965 on Sand Island and in the lagoon showed about 160 to 380 meters of carbonates and clay resting on basalt, but no phosphorite. An exploration program is needed to delineate this potential resource. Again, the National Wildlife Refuge status of much of the region limits the likelihood of mining.

Hydrothermal iron and manganese deposits are likely to occur scattered throughout the region, but as yet have not been sampled. This deposit type may have a long-term resource potential.

Shallow-water and insular aggregate for construction on Midway is ubiquitous and consists of sand and gravel composed of coral and shell. Local construction materials have been used to build two runways and a small harbor. The clearing of two seaplane lanes in the lagoon provided construction materials. Nearshore deposits are limited to the submerged reef terrace surrounding the atoll and within the lagoon. Exploration for lagoonal and nearshore sand and gravel may identify deposits that have immediate economic importance for local construction. In general, construction materials are common on this type of island, but identifying deposits where exploitation will not accelerate land loss or shoreline erosion, nor result in permanent habitat, loss is more difficult. Armor stone for use in revetments and shore protection can be mined from the reef flat and beachrock deposits. The military may possess data on the sand and gravel potential, but such documents are not presently available to us.

Shallow- to deep-water precious coral has been discovered and harvested around Midway. About 60 tonnes of pink coral has been harvested from the so-called Midway beds that occur offshore the northwestern islands of the Hawaiian Ridge. These beds were discovered in the mid 1960s and have significantly augmented the harvests of pink coral from the Mediterranean area and Japan. Precious coral likely occurs on other atolls and on seamounts and ridges in the Midway EEZ. Shallow-water black coral species typically occur in areas of steep rock faces swept by strong currents in water depths greater than 20 meters. The lagoon passages and the outer flanks of the atoll have potential sites for precious coral. However, its distribution and abundance, and therefore resource potential, are unknown. A systematic exploration program is needed to delineate this potential resource. If additional important deposits are found, they could have an immediate economic market.

\section{Summary}

Aggregate, precious coral, and insular phosphorite could have an immediate economic impact if significant deposits are found and an overriding need was identified. Exploitation of these commodities would have to address potential environmental and ecological issues. Cobalt-rich crusts have very high cobalt contents, but crusts and possibly nodules offer only an intermediate- to long-term resource potential. The other deposit types represent long-term or unknown resource potential. Research cruises dedicated to understanding the distribution, grade, and tonnage of these potential resources are recommended.

\section{Selected References}

Harper, J.R., 1988, Precious corals prospecting strategies for the South Pacific region: CCOP/SOPAC Technical Report $84,80 \mathrm{p}$.

Hein, J.R., 2004, Cobalt-rich ferromanganese crusts; global distribution, composition, origin and research activities, in Minerals other than polymetallic nodules of the International Seabed Area: Kingston, Jamaica, International Seabed Authority, Proceedings of a Workshop held on 26-30 June 2000, v. 1, p. 188-256. 
Hein, J.R., Koschinsky, A., Bau, M., Manheim, F.T., Kang, J.-K., and Roberts, L., 2000, Cobalt-rich ferromanganese crusts in the Pacific, in Cronan, D.S., ed., Handbook of marine mineral deposits: Boca Raton, Florida, CRC Press, p. 239-279.

Ladd, H.S., Tracey, J.I., Jr., and Gross, G.M., 1967, Drilling on Midway Atoll, Hawaii: Science, v. 156, p. 1088-1094.
MacDonald, G.A., 1969, Petrology of the basalt cores from Midway Atoll: U. S. Geological Survey Professional Paper 680, p. B1-B10.

Manheim, F.T., and Lane-Bostwick, C.M., 1989, Chemical composition of ferromanganese crusts in the world ocean; a review and comprehensive database: U.S. Geological Survey Open-File Report 89-020. 


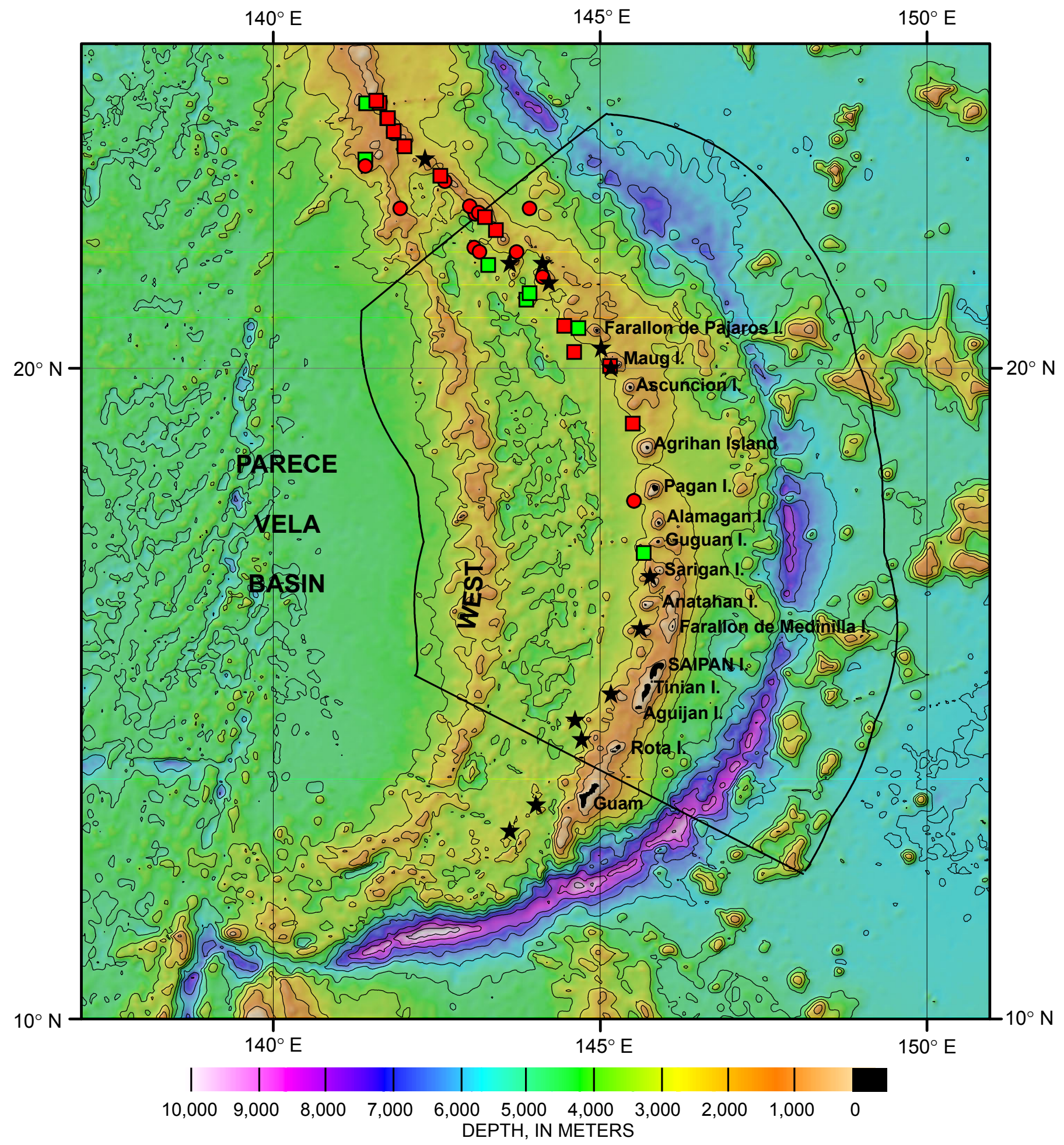

Fe-Mn crust sample sites

Hydrothermal Mn sample sites
Sample sites with both Fe-Mn crusts and hydrothermal Mn

Hydrothermal vent sites

Figure 19. Bathymetric map of the Exclusive Economic Zone (EEZ) of the Commonwealth of the Northern Mariana Islands ("K" on fig.1); black line shows EEZ boundary. Contour interval is 1,000 meters. The Guam and Japan EEZs border the Commonwealth of the Northern Mariana Islands EEZ to the south-southwest and north-northwest, respectively. 


\section{Northern Mariana Islands}

\begin{abstract}
Land area:
EEZ area:
\end{abstract}

\section{Political status:} Island minerals:
Population:

\author{
$477 \mathrm{~km}^{2}$ (14 islands) \\ $758,121 \mathrm{~km}^{2}$ (see fig. 19); \\ location shown by "K" on \\ figure 1 \\ Commonwealth in political \\ union with the United States \\ 78,252 (July 2004 estimate) \\ Phosphate, aggregate, pozzo- \\ lan
}

\section{Island History}

The Mariana Islands may have been first visited by people from Southeast Asia more than 3,500 years ago. The inhabitants became known as Chamorro, which included descendants of the original immigrants and also those who immigrated from the Caroline Islands after trade had been established between the two island groups. In 1521, Ferdinand Magellan was the first European to visit the islands, specifically Guam and Rota. Spain claimed the islands, including Guam, in 1565 and maintained control over them for more than 300 years. However, the first permanent Spanish community was not established for about 100 years after the islands were appropriated.

Guam was ceded to the United States in 1899 after the Spanish-American War and the other islands sold to Germany that same year. In 1914, after the start of World War I, Japan exercised control of the Northern Mariana Islands. The League of Nations gave control of the islands to Japan in 1920. Saipan became the center of Japanese occupation, with over 30,000 Japanese residents. The Northern Mariana Islands were sites of significant U.S.-Japanese battles during World War II. On August 15, 1945, when Japan surrendered, the U.S. military took over control of the islands. The Northern Mariana Islands was placed under U.S. administration as part of the U.N. Trust Territory of the Pacific Islands (TTPI) in 1947. The people of the Northern Mariana Islands decided to promote closer links with the United States in the early 1970s and, as a result, began negotiations for territorial status in 1972. A covenant to establish a commonwealth in political union with the United States was approved in 1976, and the new government and constitution went into effect in January 1978. The Covenant, which was implemented in its entirety in November 1986, conveyed U.S. citizenship for legal Commonwealth of the Northern Mariana Islands (CNMI) residents. In December 1990, the U.N. Security Council terminated the TTPI status for CNMI, FSM States, and the Marshall Islands.

\section{Geography}

The CNMI comprises 14 islands that delineate a 483kilometer-long archipelago (fig. 19). This archipelago sits atop the Mariana Ridge, which is about 1,200 kilometers long within the CNMI EEZ. Many seamounts occur on the ridge between the islands. The southern islands are raised limestone platforms that rest on a volcanic edifice, whereas the northern islands are entirely volcanic. Six islands have been volcanically active during historic times-Pagan, Agrihan, Asuncion, Farallon de Pajaros, Guguan, and Anatahan. In addition, at least 12 seamounts along the chain are volcanically or hydrothermally active. The islands of Saipan, Tinian, and Rota, located northeast of Guam, share the same geologic history with Guam. The CNMI EEZ shares its southern boundary with that of Guam and its northern boundary with that of the Japanese Izu-Bonin Arc. The Izu-Bonin volcanic arc is geologically a continuation of the Mariana Arc.

\section{Geologic Setting}

The Mariana volcanic arc (also called volcanic ridge or island arc) is part of a subduction system in which the Pacific Plate plunges beneath the Philippine Sea Plate and into the Earth's mantle along the Mariana Trench (see figs. 2, 19). The volcanic chain of seamounts and islands is located about 200 kilometers west of the trench axis. The Mariana Arc started to develop about 40 million years ago, and volcanic activity has occurred at various places along the arc since that time.

West of the Guam-Mariana Arc is the mostly sedimentcovered floor of the Philippine Sea (a back-arc basin), with numerous seamounts, ridges, and basins that are less than 20 million years old. The basins and ridges consist of (1) the Mariana Trough, an active back-arc spreading center located immediately west of the Mariana Arc, (2) The West Mariana Ridge, a remnant (extinct) volcanic arc, and (3) the Parece Vela Basin abyssal plain (fig. 19).

The Mariana Trench is partly filled by sediment. Many serpentine diapirs and mud volcanoes occur in the region between the trench axis and the volcanic arc. East of the trench is the sediment-covered Pacific Ocean abyssal plain. At least ten large Cretaceous ( $>65$ million years old) seamounts protrude through the abyssal plain sediment within the CNMI EEZ. These seamounts were constructed on the oldest part of the Pacific Ocean crust, which is Jurassic in age (>142 million years old).

In summary, the CNMI EEZ encompasses a variety of geologic, morphologic, and tectonic environments. These include, from east to west, (1) Cretaceous-age seamounts on the Pacific Plate abyssal plain, which includes the Magellan Seamount Province, (2) deep Mariana Trench, (3) volcanically active Mariana Arc upon which the islands of the CNMI are located, (4) Mariana Trough, a back-arc basin spreading center, (5) West Mariana Ridge, a remnant arc, and (6) Parece Vela Basin, an abandoned Tertiary back-arc basin.

\section{Offshore Mineral Deposits of the Northern Mariana Islands}

Within the EEZ of the CNMI occur near- to long-term potential mineral resources. Mineral deposits that do, or are 
likely to occur within the EEZ include:

- Cobalt-rich iron-manganese crusts on Cretaceous sea mounts

- Iron-manganese nodules

- Phosphorite deposits on Cretaceous seamounts

- Epithermal gold deposits along the active volcanic arc

- Hydrothermal manganese and iron oxide deposits along the active arc and back-arc

- Hydrothermal polymetallic sulfides and gold along the active arc and back-arc

- Insular and lagoonal phosphorite deposits

- Shallow-water sand and gravel deposits near the islands

- Shallow- and deep-water precious coral on island flanks and seamounts

Cobalt-rich iron-manganese crusts occur on the seamounts located east of the Mariana Trench. The distribution and morphology of the seamounts in that region are poorly known. The distribution, grade, and tonnage of metal-rich crusts on those seamounts are also poorly known, because no research cruise has been dedicated to their study. Data for crusts from nearby seamounts indicate that crusts on seamounts within that sector of the CNMI EEZ have an excellent potential to be thick and have high contents of cobalt, nickel, and platinum. It is recommended that these seamounts be explored for their mineral potential. These crust deposits represent an intermediate-term resource potential for cobalt, nickel, platinum, and perhaps other metals.

Crusts also occur on volcanic rocks that make up the West Mariana Ridge. Those crusts are likely to be thin, because of the relatively young age of the substrate, and of relatively low grade, because of dilution by detrital and hydrothermal minerals. These crusts would have a long-term resource potential.

Iron-manganese nodules have seldom been recovered from the abyssal-plain surface to the east of the Mariana Trench. Nodules have been recovered at depth in sediment cores, indicating that the current high rates of sedimentation do not favor nodule occurrence on the sea floor. However, bottom photographs reveal a few areas where nodules do occur. If areas of favorable nodule density and grade can be located within the CNMI EEZ, the deposits may offer an intermediate- to long-term resource potential. In the areas of the Mariana Trough, West Mariana Ridge, and Parece Vela Basin, nodules are even less likely to be present, again owing to high sediment accumulation rates.

Phosphorite deposits occur on the Cretaceous seamounts with iron-manganese crusts, and their distribution and grade are also poorly known. These deposits are typically either small, high-grade deposits or more widespread, low-grade deposits. This deposit type probably has a longterm resource potential.

Gold deposits of epithermal origin are known to occur on islands along the Yap and Belau volcanic arcs to the south and probably also occur offshore along the intersection of faults and fracture zones and in submerged calderas.
Epithermal gold has not been found in the CNMI EEZ, but geologic considerations indicate that it may occur along the Mariana Arc in submerged calderas (such as Maug and Esmeralda Bank) and in areas of back-arc spreading, such as the Mariana Trough. Recent work along the Mariana Arc supports these speculations. If high-grade gold deposits do occur offshore, they would offer a near- to intermediate-term resource.

Manganese oxides of hydrothermal origin are known to occur extensively along the Mariana, Yap, and Palau volcanic arcs. From analysis of 26 samples from the Mariana Arc, manganese averages 47 percent and zinc 0.26 percent. Manganese oxides cement sandstone and form layers within the sediments. In places the manganese deposits have high contents of molybdenum, nickel, zinc, and/or chromium. However, because large deposits of most of these metals occur on the continents, they offer only an intermediate- to longterm resource potential. It may be found that other metals of greater economic importance are enriched in the manganese oxide deposits in volcanic arcs; chromium-rich deposits along the Yap Arc were only discovered in 1991. The backarc hydrothermal manganese deposits have not been studied in detail, and their resource potential is unknown but probably represents a long-term resource.

Polymetallic sulfides, sulfates, and sulfur of hydrothermal origin have been found within the CNMI EEZ at four submarine sites along the Mariana Arc and at three sites along the eastern margin of the Mariana Trough spreading center (see fig. 19). Sulfides have not been found in Maug Caldera on the Mariana Arc, but hydrothermal activity has been documented there and hydrothermal iron oxides and iron carbonates have been found, indicating that hydrothermal sulfides are also likely to be present. In addition, hydrothermal activity has been found at seven additional sites along the Mariana Arc; those sites have not yet been explored for polymetallic sulfide deposits. Most of these discoveries are new, and the compositions of the deposits are not yet available. Volcanic-arc and back-arc polymetallic sulfides are commonly rich in gold and silver, with variable amounts of zinc, lead, and copper. For example, sulfides from the Okinawa Trough back-arc basin have very high gold and silver contents, as do the deposits in the Mariana Trough. There is a good potential to find large, high-grade polymetallic sulfide deposits along the active Mariana Arc and back-arc basin. If gold- and silver-rich polymetallic sulfides are found within the CNMI EEZ, they would have a short- to intermediate-term resource potential.

Insular phosphorites averaging 20 to 26 percent $\mathrm{P}_{2} \mathrm{O}_{5}$ occur on Saipan, Rota, Tinian, and Aguijan Islands. During Japanese occupation of the islands, phosphate mining began on Rota in 1937 and on Saipan in 1938 and continued until the United States took control of the islands in 1944. During those few years, 236,000 metric tonnes of ore was mined from Rota and 88,000 from Saipan. Rota may contain as much as 300,000 tonnes of reserves and Tinian hosts about 30,000 tonnes of reserves, both at about 23 percent $\mathrm{P}_{2} \mathrm{O}_{5}$. The reserves 
on Saipan and Aguijan are unknown. An exploration program to identify additional reserves is warranted. Lagoonal phosphate is not known to occur in the Mariana Islands.

Sand and gravel deposits occur in shallow water adjacent to much of the coastline of Saipan, Rota, and Tinian Islands. Rota and Tinian have narrow fringing reefs with pocket sand beaches. Although some offshore sand and gravel deposits exist at Rota, exploitation of these deposits and of the beach sands will have to consider environmental issues. Tinian has potentially exploitable sand and gravel deposits off Kammar Beach and probably off Invasion Beach. However, production of aggregate should presently be limited to the adequate on-island quarries because of environmental issues related to nearshore and beach mining; in addition, abandoned offshore military dump sites and marine sanctuaries warrant additional caution for offshore mining. Western Saipan has a wide barrier reef with good back-reef potential for sand and gravel. Limiting factors would include the resort on Mañagaha Island and erosion problems on Saipan. The rest of Saipan has a narrow fringing reef and small pocket beaches. Exploitation for building aggregate of numerous on-land limestone and volcanic rock outcrops in relatively remote areas would be the most environmentally sound approach. Fluvial aggregate and beach-placer deposits are limited in the CNMI. Aggregate offshore western Saipan offers a near-term resource potential and could be mined if environmental issues are addressed.

Precious coral is found in shallow to deep water at many places around the islands in the CNMI EEZ. A systematic exploration program is needed before exploitation of this resource can proceed in a controlled and informed manner. Precious coral has an immediate economic market if significant occurrences are found, but resource renewal rates must be maintained.

\section{Summary}

Sand and gravel and precious coral have immediate economic markets. Insular phosphorite and perhaps epithermal or hydrothermal gold- and silver-rich polymetallic sulfide deposits could have a near-term resource potential. Cobalt-rich crusts, iron-manganese nodules, and base-metal polymetallic sulfide deposits may offer an intermediate-term resource potential. The other deposit types may represent long-term potential resources that cannot be evaluated without additional information. Cruises are recommended to determine the distributions, grades, and tonnages of these deposits. In addition, available bathymetric maps of the CNMI EEZ are not good enough for exploration, except for a narrow swath along the volcanically active arc. Much of the CNMI EEZ should be mapped by multi-beam bathymetric and sidescan sonar techniques.

\section{Selected References}

Embley, R.W., Baker, E.T., Chadwick, W.W., Jr., Lupton, J.E., Resing, J.A., Massoth, G,J., and Nakamura, K., 2004, Explorations of Mariana arc volcanoes reveal new hydrothermal systems: EOS, Transactions of the American Geophysical Union, v. 84, no. 4, p. 37, 40.

Hein, J.R., 2004, Cobalt-rich ferromanganese crusts; global distribution, composition, origin and research activities, in Minerals other than polymetallic nodules of the International Seabed Area: Kingston, Jamaica, International Seabed Authority, Proceedings of a workshop held on 26-30 June 2000, v. 1, p. 188-256.

Hein, J.R., Fleishman, C.L., Morgenson, L.A., Bloomer, S.H., and Stern, R.J., 1987, Submarine ferromanganese deposits from the Mariana and Volcano volcanic arcs, West Pacific: U.S. Geological Survey Open-File Report 87-281, 67 p.

Hein, J.R., Moon, J.-W., Lee, K.-Y., Dowling, J.S., Kim, K.-H., Burrows, M., Park, S.H., Choi, Y.-J., Schuetze, A.A., Jung, H.S., Kin, H.-S., Lee, G.C., Park, C.-K., Son, S.K., and Park, C.Y., 1999, Co-rich Fe-Mn crusts from the Marshall Islands (Leg 1) and hydrothermal and hydrogenetic Fe-Mn deposits from Micronesia (Leg 2), KODOS 98-3 cruise, West Pacific: U.S. Geological Survey Open-File Report 99-412, 63 p.

Hein, J.R., Koschinsky, A., Bau, M., Manheim, F.T., Kang, J.K., and Roberts, L., 2000, Cobalt-rich ferromanganese crusts in the Pacific, in Cronan, D.S., ed., Handbook of marine mineral deposits: Boca Raton, Florida, CRC Press, p. 239279.

National Oceanic and Atmospheric Administration, Submarine ring of fire 20004-Mariana Arc, at http://oceanexplorer. noaa.gov/explorations/04fire/welcome.html, accessed September 2005.

Rodgers, J., 1948, Phosphate deposits of the former Japanese Islands in the Pacific; a reconnaissance report: Economic Geology, v. 43, p. 400-407.

Schulz, M.S., and Hein, J.R., 1991, Petrography and chemistry of hydrothermal manganese oxyhydroxides from the Mariana and Izu-Bonin Volcanic arcs, West Pacific: U.S. Geological Survey Open-File Report 91-557, 80 p.

Stüben, D., Bloomer, S.H., Taïbi, N.E., Neumann, Th., Bendel, V., Püschel, U., Barone, A., Lange, A., Wu, S., Li, C., and Zhang, D., 1992, First results of study of sulphur-rich hydrothermal activity from an island-arc environment; Esmeralda Bank in the Mariana Arc: Marine Geology, v. 103, p. 521-528.

Usui, A., and Someya, M., 1997, Distribution and composition of hydrogenetic and hydrothermal manganese deposits in the northwest Pacific, in Nicholson, K., Hein, J.R., Bühn, B., and Dasgupta, S., eds., Manganese mineralization; geochemistry and mineralogy of terrestrial and marine deposits: Geological Society of London Special Publication 119, p. 177-198. 
$160^{\circ} \mathrm{E}$

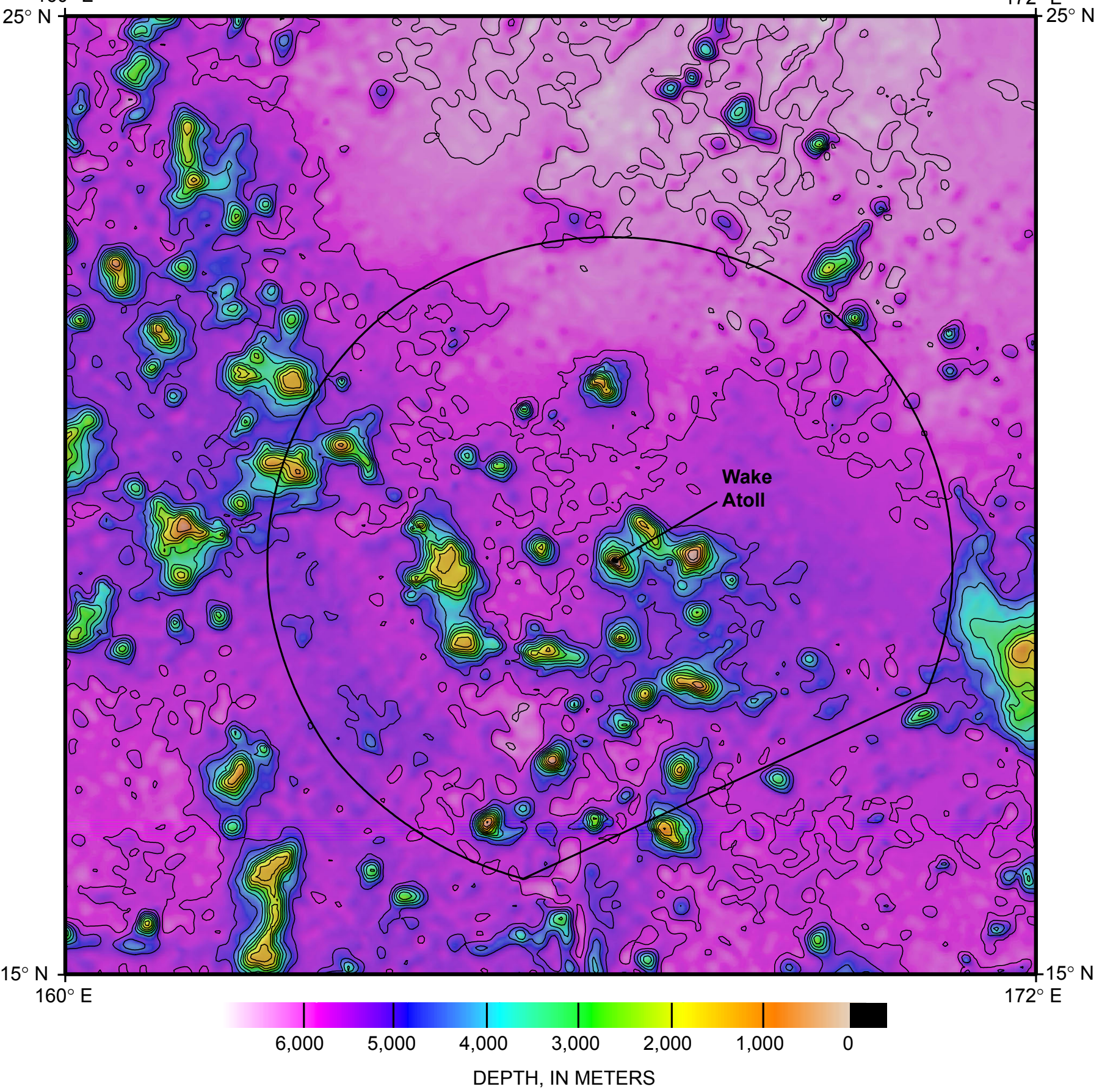

Figure 20. Bathymetric map of the Exclusive Economic Zone (EEZ) of Wake Atoll (“L” on fig.1); black line shows EEZ boundary. Contour interval is $\mathbf{5 0 0}$ meters. The Republic of the Marshall Islands EEZ borders the Wake Atoll EEZ to the south-southeast. 


\section{Wake Atoll}

\author{
Land area: \\ EEZ area: \\ Political status: \\ Population: \\ Island minerals:
}

$6.5 \mathrm{~km}^{2}$

$406,307 \mathrm{~km}^{2}$ (see fig. 20); location

shown by "L" on figure 1

Territory of the United States

200 (July 2003 estimate)

Aggregate

\section{Island History}

The great distances that separate Wake Atoll from the northern Marshall Islands and from other islands in the region, and its barren nature, suggest that Wake Atoll may never have been permanently inhabited by the migrants from the Malaysian-Indonesian region that settled the Marshall Islands to the south thousands of years ago. There have been no reports of artifacts from that wave of migrations. Wake was discovered by Captain William Wake of the British schooner Prince William Henry in 1796, although there are claims that it was visited by Europeans as early as 1568 . The position of Wake was determined in December 1841 by Charles Wilkes, leader of a U.S. exploring expedition. The two smaller of the three islets on Wake Atoll were named in honor of Wilkes and the artist Titian Peale on the same cruise by A. Wetmore of the USS Tanager expedition in July 1923. The U.S. flag was raised on Wake in 1898 by General F.V. Green from the SS China and again by General Merritt from the U.S. Army Transport Thomas.

The United States formally annexed Wake under President William McKinley on 17 January 1899 in a ceremony on Wake conducted by Commander E.D. Taussig of the USS Bennington. The 1923 Tanager expedition mapped Wake Atoll and cataloged its biota. The U.S. Navy took over jurisdiction of Wake in 1935 by Executive Order. Pan American Airways constructed an airport during that same year. President F.D. Roosevelt made Wake a National Defense area in February1941, and it was a naval and air base from 1939 to 1941. Wake was occupied by Japanese forces during World War II after the bombing of Pearl Harbor. Wake was then transferred back to the United States in surrender documents and reoccupied by the United States in September 1945. President J.F. Kennedy, by Executive Order No. 11048 on 5 September 1962, made the Secretary of the Interior responsible for the civil administration of the atoll. The order vested in the Secretary all executive and legislative authority necessary for that administration and all judicial authority other than the authority of the U.S. District Court for the District of Hawai'i. The Congress later extended the jurisdiction of the U.S. District Court for the District of Hawai'i to all civil and criminal cases arising on or within Wake Atoll. Since 1 October 1994, the Ballistic Missile Defense Organization (within the Office of the Secretary of Defense) has funded administration on Wake, which the U.S. Army Space and Strategic Defense Command carries out under a use permit. The atoll has approximately 200 inhabitants, all contract personnel.

\section{Geography}

Wake Atoll is about 3,714 kilometers west of Honolulu and 2,426 kilometers northeast of Guam. Wake Atoll measures about 7.8 by 3.3 kilometers and consists of three islets, Wake, Peale, and Wilkes, leaving only the northwest rim without continuously emergent land. Causeways connect these three islets. The highest and average elevations are 6.4 and 3.7 meters above sea level, respectively. Each of the three islets has a point that is near the maximum elevation. Beaches along most of the coast of the three islets are very wide, averaging about 90 meters. The shallow lagoon has a maximum depth of about 4.5 meters and is completely enclosed by the atoll reef rim except for a single artificial channel on the southwest side that separates Wilkes and Wake islets. The lagoon is generally less than 1 meter deep in its southeast quadrant, where most development is located. No drilling or seismic studies, to our knowledge, have been attempted on Wake to establish the thickness of the coral cap resting on the underlying Cretaceous-age volcanic structure, the nature of the contact between the two, nor the possible presence at depth of any mineral resource.

\section{Geologic Setting}

Many large to small seamounts formed along the Southern Wake seamount hot-spot trail from 120 to 97 million years ago (Cretaceous). Some of those volcanoes showed volcanic rejuvenation later in the Cretaceous, about 90 to 85 million years ago. Seamounts within the Wake Atoll EEZ, including the edifice on which Wake Atoll sits, likely fall within that age range, although only one seamount in the EEZ has been dated. A sediment-covered abyssal plain ranging in water depth from about 5,200 to 5,800 meters surrounds these seamounts.

\section{Offshore Mineral Deposits of Wake Atoll}

The southern EEZ boundary is shared with that of the Republic of the Marshall Islands. Short- to long-term potential mineral resources likely occur within the EEZ of Wake Atoll, although their grades, tonnages, and distributions are unknown. Most of our conclusions are based on inferences from the geologic setting and information from surrounding areas, especially the Marshall Islands. Mineral deposits within the EEZ may include:

- Cobalt-rich iron-manganese crusts on sea mounts

- Iron-manganese nodules on the abyssal plain

- Phosphorite deposits on seamounts 
- Hydrothermal iron and manganese deposits on seamounts

- Insular/lagoonal phosphorite on Wake Atoll

- Shallow-water sand and gravel (aggregate) on and adjacent to Wake Atoll

- Shallow- to deep-water precious coral on sea mount and island flanks

Cobalt-rich iron-manganese crusts have not been studied within the Wake Atoll EEZ. However, extensive work has been done in the Marshall Islands to the south by the USGS and by government agencies of Korea and Japan. Extensive proprietary work by Japanese agencies has also taken place in adjacent international waters. All data indicate that thick crusts rich in cobalt, nickel, and platinum should occur on seamounts within the Wake EEZ. Work done by the USGS in cooperation with the Korea Ocean Research and Development Institute to the south in the Marshall Islands EEZ and with Scripps Institute of Oceanography in international waters to the west of the Wake EEZ show that the crusts are more enriched in platinum than those in all other Pacific areas. Mean cobalt, copper, nickel, and platinum contents for 20 crust samples collected near the Wake EEZ are 0.64 percent, 0.48 percent, 0.13 percent, and 0.6 grams per ton, respectively. The Wake EEZ crusts may likewise contain high metal concentrations. The extent of development of crust deposits with high metal contents is unknown, but the large number and size of seamounts in the EEZ indicate that an intermediate-term resource potential may occur for cobalt, nickel, and possibly platinum and other metals. It is recommended that an exploration program for crusts be carried out in the Wake EEZ.

Iron-manganese nodules appear to be common on the few bottom photographs taken of the sediment surface in the deep-water abyssal plain that surrounds the seamounts in the Wake EEZ. Little work has been done on these deposits, and nodule distribution and grade are poorly known. The few bottom photographic stations scattered throughout the vast region of the North Pacific Ocean suggest that nodule coverage is locally high and possibly high over large areas. Proprietary work by Japanese scientists in nearby areas also indicates extensive nodule coverage and high copper and nickel contents. The low sediment accumulation rates in the area also favor nodule growth. If areas of favorable nodule coverage and grades can be located within the Wake EEZ, these nodules would offer an intermediate-term potential resource.

Phosphorite deposits on seamounts within the Wake EEZ have not been sampled. However, samples taken from adjacent areas indicate that phosphorite might be widespread on seamounts in the Wake EEZ. These deposits are typically either small, high-grade deposits or more widespread, low-grade deposits. This deposit type may have a long-term resource potential.

Insular phosphorite deposits are not known to occur on Wake Atoll, but all the conditions are appropriate for them to have formed, especially within the enclosed lagoon. An exploration program should include sampling of islet outcrops and a drilling program on the islets and in the lagoon. Some data and samples may already exist from construction projects undertaken in support of military activities. There would be a nearterm resource potential if a suitable deposit were found.

Hydrothermal iron and manganese deposits are likely to occur scattered throughout the region, but as yet have not been sampled. This deposit type may have a long-term resource potential.

Shallow-water and insular aggregate for construction uses on Wake consists of sand and gravel composed of coral and shell. Construction materials are ubiquitous on the atoll, which is composed predominantly of unconsolidated sand, gravel, and reef deposits. Extensive use of construction materials has occurred, including the building of a single large runway and a small harbor. Nearshore deposits are limited to the submerged reef terrace surrounding the atoll and areas within the lagoon. In general, construction materials are common on this type of island, but identifying deposits where exploitation will not accelerate land loss or shoreline erosion, nor result in permanent habitat loss, is difficult. Armor stone for use in revetments and shore protection can be mined from the reef flat and beachrock deposits. Exploration for lagoonal and nearshore sand and gravel may identify deposits that have immediate economic importance. The military likely possesses information on the sand and gravel potential, but such documents are not presently available to us.

Shallow- to deep-water precious coral likely occurs on seamounts and island flanks within the Wake EEZ. Its distribution, abundance, and resource potential are unknown, and a systematic exploration program is needed to delineate this potential resource. If important deposits are found, they would have an immediate economic market.

\section{Summary}

Aggregate, precious coral, and insular phosphorite could have an immediate economic impact if significant deposits and markets are found. Exploitation of these commodities would have to address environmental and ecological issues. Cobalt-rich crusts and iron-manganese nodules may offer an intermediate-term resource potential. The other deposit types represent long-term or unknown resource potential. Without detailed data, it is difficult to assess the resources of these mineral deposit types within the EEZ. Research cruises dedicated to understanding the distribution, grade, and tonnage of these potential resources are recommended.

\section{Selected References}

Hein, J.R., 2004, Cobalt-rich ferromanganese crusts; global distribution, composition, origin and research activities, in Minerals other than polymetallic nodules of the International Seabed Area: Kingston, Jamaica, International Seabed Authority, Proceedings of a workshop held on 2630 June 2000, v. 1, p. 188-256.

Hein, J.R., Kang, J-K., Schulz, M.S., Park, B-K., Kirschen- 
baum, H., Yoon, S-H., Olson, R.L., Smith, V.K., Park, D-W., Riddle, G.O., Quinterno, P.J., Lee, Y-O., Davis, A.S., Kim, S.R., Pringle, M.S., Choi, D-L., Pickthorn, L.B., Schlanger, S.O., Duennebier, F.K., Bergersen, D.D., and Lincoln, J.M., 1990, Geological, geochemical, geophysical, and oceanographic data and interpretations of seamounts and Co-rich ferromanganese crusts from the Marshall Islands, KORDI-USGS R.V. Farnella Cruise F10-89-CP: U.S. Geological Survey Open-File Report 90407, 246pp.

Hein, J.R., Koschinsky, A., Bau, M., Manheim, F.T., Kang, J.-K., and Roberts, L., 2000, Cobalt-rich ferromanganese crusts in the Pacific, in Cronan, D.S., ed., Handbook of marine mineral deposits: Boca Raton, Florida, CRC Press, p. 239-279.

Hein, J.R., Zielinski, S.E., Staudigel, H., Chang, S.-W., Greene, M., and Pringle, M.S., 1997, Composition of Corich ferromanganese crusts and substrate rocks from the NW Marshall Islands and international waters to the north, Tunes 6 cruise: U.S. Geological Survey Open-File Report 97-482, 65 p.

Koppers, A.A.P., 1998, ${ }^{40} \mathrm{Ar} /{ }^{39} \mathrm{Ar}$ geochronology and isotope geochemistry of the West Pacific Seamount Province: The Netherlands, Vrije University, unpublished Ph.D. dissertation, $263 \mathrm{p}$.

Piper, D.Z., Swint-Ike, T.R., and McCoy, F.W., 1987, Distribution of ferromanganese nodules in the Pacific Ocean: Chemie der Erde, v. 46, p. 171-184. 


\section{Conclusions}

Little information is available on which to base a resource assessment for minerals that may occur within the EEZs of the twelve islands or island groups considered here. Exploitable shallow-water and insular sand and gravel deposits occur within each of the twelve EEZs. These deposits are readily available and have been or can be developed. The main challenge for their exploitation is to proceed in an environmentally sound way. Shallow- and deep-water precious corals are likely to occur in each EEZ, but it is not known if they occur with the quality and tonnage required for large-scale exploitation. Precious coral has been exploited with small-scale operations in several of the EEZs. The main concern is exploiting precious coral to an extent that it cannot recover. Precious coral is the only potentially renewable resource considered here.

Each of the twelve EEZs has a high likelihood for the occurrence of an exploitable resource for one of the three main deep-ocean mineral-deposit types: cobalt-rich iron-manganese crusts, iron-manganese nodules, and polymetallic sulfides (see fig. 21). This likelihood is based on the geologic and oceanographic settings, as well as the size of the area available in which a particular deposit type can form. American Samoa, Howland-Baker Islands, and Jarvis Island are more likely to contain nodule deposits, whereas the Northern Mariana Islands, Guam, and Belau are more likely to contain polymetallic sulfide deposits. The remainder of the EEZs are likely to contain cobalt-rich crust deposits as the dominant deep-water deposit type. The Marshall Islands EEZ has been explored to a far greater extent than any other, with cobalt-rich crusts as the main focus. However, even with that relatively intense activity, data are too few to make a robust resource analysis. Each new research cruise to these EEZs brings new discoveries that contribute to our fundamental understanding of their potential mineral resources. An excellent example is the recent (2004) U.S. NOAA cruise to the CNMI that made many new resource-applicable discoveries (http://oceanexplorer.noaa. gov/explorations/04fire/welcome.html). The clear and fundamental message from our analysis is that the data required to make resource assessments for the Pacific EEZs of U.S. affiliation are not yet available. A national program should be developed to collect the data required to make those assessments and thereby provide the knowledge needed to make informed and sound policy.

\section{Acknowledgements}

We thank D.L. Mosier, R.A. Koski, Peter Stauffer, and H. Gibbons of the USGS for helpful comments on this manuscript. Many websites were consulted for historical and geographic background information, including those of the U.S. Office of Insular Affairs, the U.S. Department of State, government and cultural agencies of Federated States of Micronesia, Republic of the Marshall Islands, and Republic of Belau, and others.

\section{Appendix 1. Metric System Conversion Factors}

\begin{tabular}{lc} 
To change & Multiply by \\
\cline { 2 - 2 } Kilometers to miles (statute) & 0.62 \\
Kilometers to miles (nautical) & 0.54 \\
$\begin{array}{l}\text { Square kilometers to square } \\
\quad \text { miles (statute) }\end{array}$ & 0.39 \\
$\begin{array}{l}\text { Square kilometers to square } \\
\quad \text { miles (nautical) }\end{array}$ & 0.29 \\
$\quad \begin{array}{l}\text { Miles (nautical) to kilometers } \\
\text { Square miles (nautical) to }\end{array}$ & 1.85 \\
$\quad$ square kilometers & \\
Millimeters to inches & 3.43 \\
Centimeters to inches & 0.039 \\
Meters to feet & 0.39
\end{tabular}

\section{Appendix 2. Definitions and Explanations}

Carbonate ooze. A sediment composed of greater than 70 percent biogenic calcium carbonate $\left(\mathrm{CaCO}_{3}\right)$ mud and silt. The biogenic carbonate consists mostly of plankton, predominantly foraminifera and nannoplankton tests.

Cobalt-rich iron-manganese crust. Iron-hydroxide and manganese-oxide (ferromanganese) deposits formed from direct precipitation of minerals from sea water onto hard-rock substrates, thereby forming crusts and pavements. Crusts contain minor but potentially economically important concentrations of cobalt, titanium, cerium, zirconium, nickel, platinum, and other metal and rare-earth elements. Minimum conditions considered for mining fall within the following ranges as determined by different workers: minimum cobalt content of 0.6 to 0.8 percent; minimum crust thickness of 25 to 40 millimeters; minimum tonnage of 20 kilograms of crust per square meter.

Epithermal deposit. A mineral deposit formed by hydrothermal processes within about 1 kilometer of the Earth's surface at temperatures of about 50 to $200^{\circ} \mathrm{C}$.

Exclusive Economic Zone (EEZ). A zone 200 nautical miles (370 kilometers) wide that surrounds each island or island nation. EEZ boundaries shown in this circular are unofficial and were constructed by drawing arcs with a radius of 200 nautical miles from emergent parts of islands and lines equidistant between islands of different nations within 200 nautical miles of one another.

GLORIA. A digital side-scan sonar system that images a wide swath of sea floor using reflected sound waves. Thus, large areas of the sea floor can be quickly mapped. It is an acronym for Geological LOng-Range Inclined Asdic. Detailed information can be found on the USGS Web site: U.S. exclusive economic zone (EEZ) GLORIA mapping program, http:// coastalmap.marine.usgs.gov/gloria (accessed September 2005). 


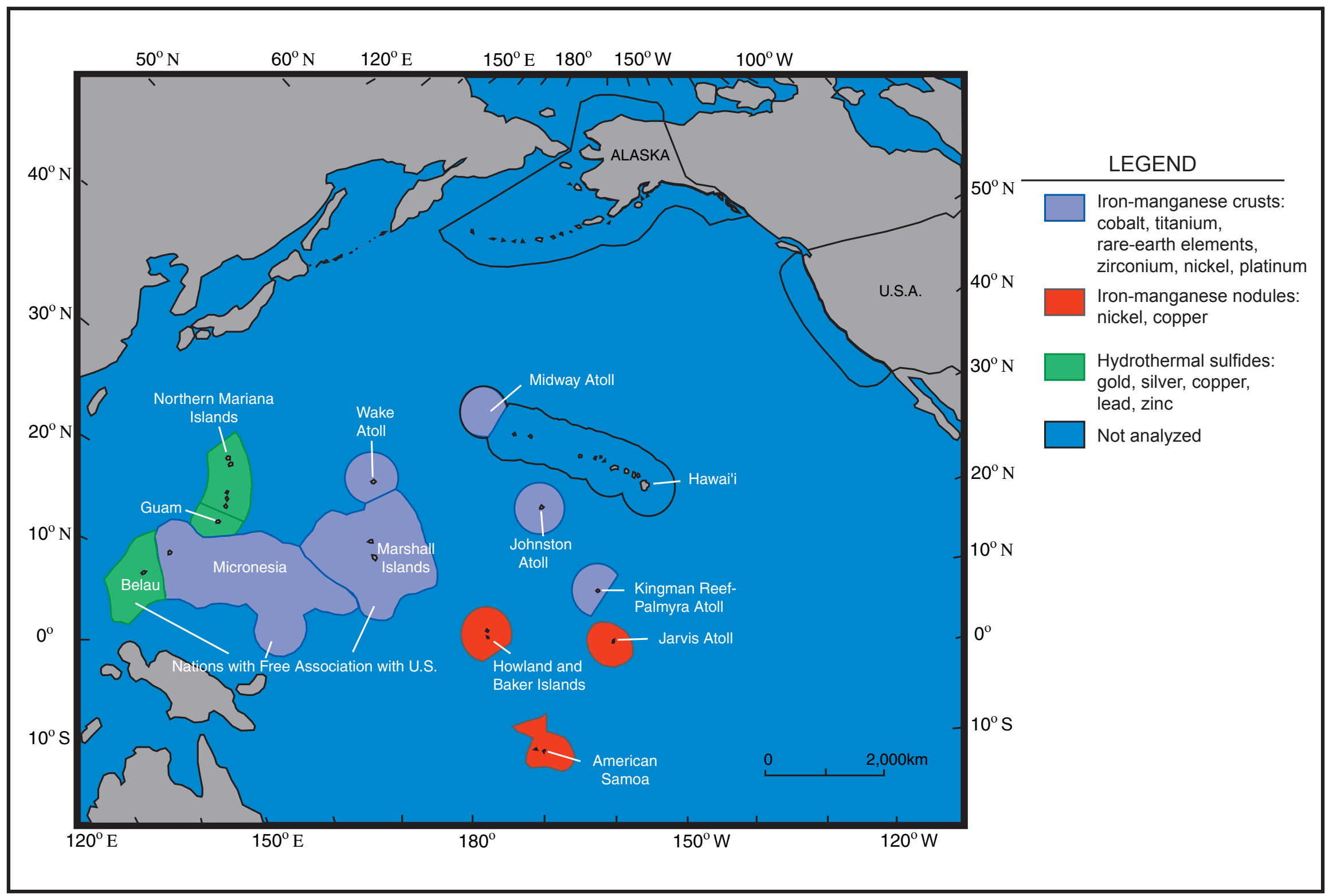

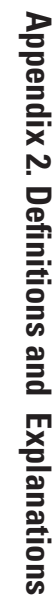

Figure 21. Main potential deep-water mineral deposit type and contained metals for each Pacific EEZ of U.S. affiliation. 
Hydrothermal deposits. A mineral deposit formed by precipitation from an aqueous fluid that is hotter than the ambient environment. These hydrothermal fluids are produced and circulate within the ocean crust by the heat of magmatic and volcanic processes. The fluid is usually seawater chemically altered by interaction with rocks that make up the ocean crust. Temperatures range from a few degrees above bottomwater temperatures to about $650^{\circ} \mathrm{C}$.

Iron-manganese nodules. Nodular deposits of iron hydroxide and manganese oxide (ferromanganese) that form on or near the sediment surface from direct precipitation of minerals from seawater and sediment pore waters. The nodular form reflects accretion of layers about a nucleus composed of a rock fragment or other material and episodic turning of the nodule on the sea floor throughout its growth history. Nodules are typically 1 to 6 centimeters in diameter. A general consensus is that a first-generation mine site requires an average abundance of nodules of 10 (minimum 5) kilograms per square meter, and the nodules should have an average nickelplus-copper content of 2.27 percent (minimum 1.18 percent).

Phosphorite. Sedimentary deposit of calcium phosphate that formed by precipitation from sediment and rock-pore fluids and by replacement of carbonate (limestone) rock and sediment. Phosphorite commonly contains chlorine, fluorine, and carbonate. Phosphorite forms on the flanks of seamounts, on the tops of submarine banks, and within reef islands and atoll lagoons. Phosphorite can also form from bird droppings (guano). Phosphorite is used mainly in agriculture as a fertilizer and in the food and beverage industry as a source of phosphoric acid.

Polymetallic sulfides/sulfates. Hydrothermally formed deposits of sulfide and sulfate minerals that contain concentrations of metals, including copper, lead, zinc, gold, and silver. Parts of the EEZs of Papua New Guinea, New Zealand, and Fiji have been, or are in the process of being, leased for exploration for polymetallic sulfides.

Pozzolan. Siliceous volcanic tuff (ash) that can be finely ground and combined in cement.

Pumice. Highly vesicular, glassy volcanic rock that is commonly buoyant enough to float. It is used as an abrasive and in lightweight cement.

Precious coral. The finest quality of coral, judged on the basis of beauty, color, hardness, and rarity. Precious corals include red and pink varieties (genus Corrallium), which can be found in water as deep as 1,500 meters. Black corals (Antipathes) occur in water depths from near the surface to about 5,000 meters, but mostly between 10 and 100 meters. Gold corals (Gerardia and Primnoa) occur in deep water (mostly 300 to 450 meters), as do bamboo corals (Acanella and Lepidisis). All these corals thrive in areas with hard substrates, little sediment input, and near-vertical faces with strong currents. The collection is prohibited for several species of corals in these genera, which are listed by the Convention on International Trade in Endangered Species (CITES).

Resource potential. We define "near-term" (also called "short-term"), "intermediate-term," and "long-term" potential resource to mean, respectively, within the next 25 years, 25 to 50 years, and more than 50 years. Even though a particular commodity may be given the same ranking for several EEZs, the global market and other factors may not support mining from more than one or two of the EEZs for that commodity Competing mining operations, technology innovations, environmental concerns, and changing economic, political, security, and land-use issues could significantly modify the resource potential estimates for the commodities considered here.

Seamount. A submarine volcano that may be active or may have been extinct for tens of millions of years. Seamounts do not extend above the ocean surface as islands, although they may have done so at one time. Flat-topped seamounts are called guyots and were at one time islands. Their tops were eroded flat by waves and the edifices sank following cessation of volcanic construction. Conical seamounts were likely never islands.

Siliceous ooze. A sediment composed of greater than 70 percent biogenic silica mud and silt. The biogenic silica $\left(\mathrm{SiO}_{2} \cdot \mathrm{nH}_{2} \mathrm{O}\right)$ consists mostly of plankton, predominantly diatom frustules and radiolarian tests.

Skarn. A rock formed by chemical and physical alteration of a carbonate rock (limestone or dolomite) as the result of fluids and heat from of an igneous intrusion (contact metamorphism and metasomatism). Garnet-rich carbonate rocks and associated ore deposits may result from this transformation.

\section{Appendix 3. Acronyms and Abbreviations}

CNMI.

DOS.

EEZ.

FSM.

ISA.

MMS.

NOAA.

OIA.

RMI.

SOPAC.

U.N.

USGS.
Commonwealth of the Northern

Mariana Islands

U.S. Department of State

Exclusive Economic Zone

Federated States of Micronesia

International Seabed Authority

U.S. Minerals Management Service

U.S. National Oceanic and Atmospheric Administration

U.S. Office of Insular Affairs

Republic of the Marshall Islands

South Pacific Applied Geoscience

Commission

United Nations

United States Geological Survey 